University of Rhode Island

DigitalCommons@URI

Open Access Dissertations

2020

\title{
SALT MARSH MANAGEMENT: MONITORING THREATS AND IMPLEMENTING CLIMATE ADAPTATION INITIATIVES
}

Danielle C. Perry

University of Rhode Island, dperry017@gmail.com

Follow this and additional works at: https://digitalcommons.uri.edu/oa_diss

\section{Recommended Citation}

Perry, Danielle C., "SALT MARSH MANAGEMENT: MONITORING THREATS AND IMPLEMENTING CLIMATE ADAPTATION INITIATIVES" (2020). Open Access Dissertations. Paper 1160.

https://digitalcommons.uri.edu/oa_diss/1160

This Dissertation is brought to you for free and open access by DigitalCommons@URI. It has been accepted for inclusion in Open Access Dissertations by an authorized administrator of DigitalCommons@URI. For more information, please contact digitalcommons-group@uri.edu. 


\title{
SALT MARSH MANAGEMENT: MONITORING THREATS AND IMPLEMENTING CLIMATE ADAPTATION INITIATIVES
}

BY

DANIELLE C. PERRY

\author{
A DISSERTATION SUBMITTED IN PARTIAL FULFILLMENT OF THE \\ REQUIREMENTS FOR THE DEGREE OF \\ DOCTOR OF PHILOSOPHY \\ IN \\ BIOLOGICAL AND ENVIRONMENTAL SCIENCES
}

UNIVERSITY OF RHODE ISLAND 2020 
DOCTOR OF PHILOSOPHY IN BIOLOGICAL AND ENVIRONMENTAL

SCIENCES DISSERTATION

$\mathrm{OF}$

DANIELLE PERRY

APPROVED:

Dissertation Committee:

Major Professor Carol Thornber

Mark Stolt

Austin Humphries

Nasser H. Zawia

DEAN OF THE GRADUATE SCHOOL

UNIVERSITY OF RHODE ISLAND

2020 


\begin{abstract}
Salt marshes serve as important coastal resources both economically and environmentally and are particularly susceptible to the negative implications of climate change. As climate change impacts become more prevalent, it is important to understand how salt marshes will respond. Two climate change impacts on salt marshes are macroalgae inundation and accelerated relative sea-level rise (hereafter referred to as SLR). Due to warming temperatures and sea level rise, salt marshes can be inundated by macroalgae through tidal movement, and the impacts of this excess macroalgal accumulation are poorly understood. Sea level rise also has negative implications on salt marsh by leading to vegetation die-back and ultimately salt marsh loss. Coastal managers within Rhode Island have successfully collaborated to implement climate change adaptation projects through strategic planning and communication. This dissertation highlights the important steps of salt marsh management: 1) Identifying the impacts of potential salt marsh threats (Chapter 1), 2) Monitoring salt marsh response to climate change adaptation projects (Chapter 2), and 3) Describing the important steps to plan and implement climate change adaptation projects (Chapter 3).

Chapter 1 focuses on the impacts of macroalgal densities within Rhode Island on salt marsh environments. In this study, we investigated how current, relatively low density ephemeral (Ulva spp.) and perennial (Fucus spp.) algal wrack coverage impacts Spartina alterniflora (low marsh plant) survival and associated greenhouse gas fluxes. We created mesocosms with $S$. alterniflora-vegetated soil cores using a 2 X 2 factorial design with Fucus and Ulva present or absent to test the effects of
\end{abstract}


macroalgal inundation. We found that $S$. alterniflora was resilient to these densities of macroalgal coverage, and this coverage did not significantly impact greenhouse gas fluxes.

In Chapter 2, we investigated the impacts of two climate change adaptation projects, hydrological restoration (dredged runnels) and sediment enhancement, that have been implemented in Rhode Island to combat the effects of sea level rise within salt marshes. Here, we investigated the impacts of these adaptation techniques on soil properties, vegetation composition, and greenhouse gas fluxes (methane and carbon dioxide). We found that plant density in certain runnel areas increased after runnels were installed and runnels assisted in maintaining Spartina patens (high marsh plant) coverage. Carbon dioxide uptake increased in a runnel treatment and control as vegetation increased over time. Sediment enhancement treatment did not lead to vegetation or belowground biomass recolonization and produced insignificant greenhouse gas fluxes.

Chapter 3 focuses on the incorporation of adaptive management into climate change adaptation implementation. This chapter describes the techniques and mechanisms used by the Rhode Island Coastal Resources Management Council to implement an adaptive management approach to restore a drowning salt marsh using the climate adaptation strategy, sediment enhancement. Through effective communication and active stakeholder involvement, this project successfully incorporated interdisciplinary partner and stakeholder collaboration and developed an iterative learning strategy that highlights the adaptive management method. 


\section{ACKNOWLEDGMENTS}

First and foremost, I would like to thank my adviser Carol Thornber for her guidance and support throughout my graduate studies. Her advice and mentorship have made me a better ecologist, writer and science communicator, and has helped me become a more well-rounded scientist. I would like to thank David Prescott for introducing me to the world of coastal management. Without his guidance and mentorship, I would not have reached my goal of being a coastal climate adaptation ecologist. Wenley Ferguson, your support, guidance, and teachings, have helped shape this dissertation and helped me accomplish research that is directly in line with my goals. Your influence has greatly enhanced my skills and prepared me for my Climate Adaptation Ecologist position at Mass Audubon. A special thank you to Caitlin Chaffee and Cathy Wigand for allowing me the opportunity to experience coastal management first-hand, which has been invaluable as a graduate student and as I enter this professional field. Without these individuals this dissertation would not have been possible, and I would not have had this graduate research experience that I am very proud of and grateful for.

I would also like to thank my committee members, Serena Moseman-Valtierra and Rose Martin for helping me hone my skills as a salt marsh ecologist as well as Austin Humphries and Mark Stolt for their insights and advice as I was developing my research and dissertation. Special thanks to Amber Hardy for teaching me soil science. This work could not have been completed without all the wonderful people who have helped me in the field and lab: Joey Loffredo, Joe Bishop, Michaela Smith, Kate Szura, Brielle 
Michener, Jacob Cytrynbaum, Max Zavell, Moira Sharkey, Maggie Rodrigue, Nick Castro, and Aidan Barry. Thank you to Christina De Jesus, Talya Ten Brink, Melvin Alvarez, Kevin Wong, Cassie Raker, Sam Gurr, Amy Zyck, and Zac Chejanovski for keeping me levelheaded and helping keep things in perspective.

Another special group that needs thanking is the faculty involved in the SciWrite Program. Special thanks to Caroline Gottschalk Druschke, Ingrid Lofgren, and Nancy Karraker for teaching me to know my audience and introducing me to the science communication field.

Funding for this research was provided by the National Science Foundation Graduate Research Fellowship Program (GRFP) (grant number DGE-1747454); National Science Foundation Graduate Research Internship Program (GRIP); National Science Foundation Established Program to Simulate Competitive Research (EPSCoR) Cooperative Agreement [grant numbers \#EPS-1004057 and \#OIA-1655221]; University of Rhode Island's Enhancement of Graduate Research Award; Special thank you to US Fish and Wildlife Service for granting permits to complete this research.

Lastly, I'd like to dedicate this dissertation to my family. My parents, Carey and Pauline Perry who taught me from a young age that I can achieve anything in life if I was willing to work for it. My mom who pushed me to work hard before I learned to push myself. My dad who was the first to tell me I would make a good marine biologist. My sister, Simone, for her continuous support. José, who makes the word "nerd" sound endearing. To my Wolfpack, who has stood by me for all the important milestones in my life and everything in between. 


\section{PREFACE}

This dissertation is being submitted in manuscript format. It is comprised of three chapters each of which have been submitted, or are in preparation of submission, for peer-reviewed publication. Chapter one, "Greenhouse gas response and Spartina alterniflora resilience to macroalgal exposure," has been published in the journal, Aquatic Botany. Chapter two, "Monitoring salt marsh vegetation and soil response to climate change adaptation" is in preparation for submission to the journal, Biological Conservation. Chapter three, "Successful implementation of adaptive management into a climate change adaptation strategy," has been accepted pending revisions to the Journal of Environmental Management. 


\section{TABLE OF CONTENTS}

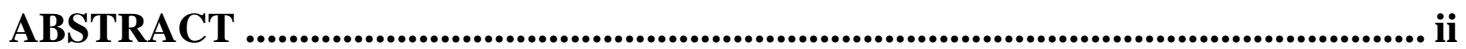

ACKNOWLEDGMENTS........................................................................................... iv

PREFACE

TABLE OF CONTENTS ................................................................................................. vii

LIST OF TABLES .......................................................................................................... viii

LIST OF FIGURES

CHAPTER 1

GREENHOUSE GAS RESPONSE AND SPARTINA ALTERNIFLORA

RESLIENCE TO MACROALGAL EXPOSURE .............................................

\section{CHAPTER 2}

MONITORING SALT MARSH VEGETATION AND SOIL RESPONSE TO

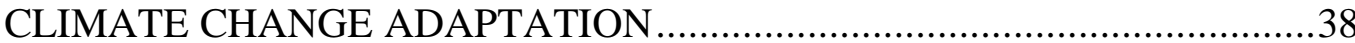

\section{CHAPTER 3}

SUCCESSFUL IMPLEMENTATION OF ADAPTIVE MANAGEMENT INTO

A CLIMATE CHANGE ADAPTATION STRATEGY ….................................73 


\section{LIST OF TABLES}

TABLE

PAGE

\section{Chapter 1}

Table 1. Ambient seawater average nutrient content. These are the mean values $( \pm 1$ standard error) from June-September 2016, the duration of the experiment. Data is obtained from Narragansett Bay Long-Term Plankton Time Series at https://web.uri.edu/plankton/data/ at Narragansett Bay Station Two. 20

Table 2. Statistical result of Spartina alterniflora core porewater analysis

Table 3. Tukey post hoc test results of the Spartina alterniflora stem nitrogen content analysis. Conditions not connected by same letter represent significant differences. .22

\section{Chapter 2}

Table 1. Average percent cover of open water, Spartina alterniflora (dominant low marsh species) and Spartina patens (dominant high marsh species) before the runnels

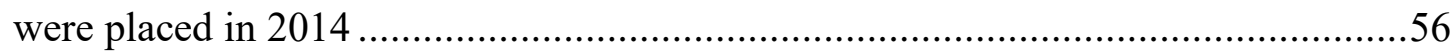

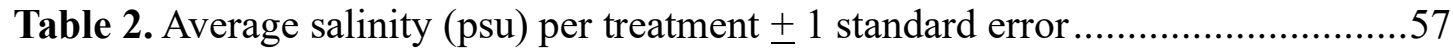

Table 3. Average percent moisture per treatment \pm 1 standard error......................58

Table 4. Average $\mathrm{pH}(5 \mathrm{~cm}$ depth) per treatment \pm 1 standard error .......................59

\section{Chapter 3}

Table 1. Partners, stakeholders, and decision-makers and their roles for the Quonnie

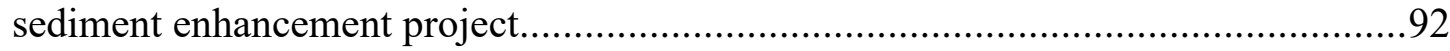

Table 2. Monitoring targets for Quonnie sediment enhancement project

Table 3. Communication tips for working with the town, public, and other stakeholders. 
Table 4. Permits needed for the 30-acre Quonnie sediment enhancement dredge

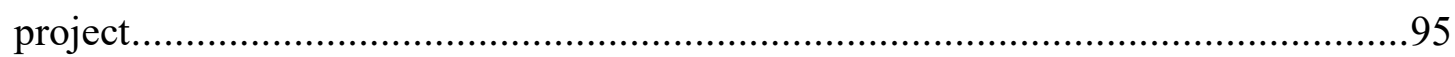

Table 5. Quonnie and Ninigret timeline of major events and project progression .....96 


\section{LIST OF FIGURES}

FIGURE

PAGE

\section{Chapter 1}

Figure 1a. Schematic showing experimental mesocosm design, with Spartina alterniflora and varying macroalgal wrack treatments, $\mathrm{n}=5$ (left to right: control, Fucus 6, Ulva 6, Mix 3, Mix 6). The green-blade alga is Ulva and the branched alga is Fucus. .23

Figure 1b. Photo of experimental set up at the Marine Science Research Facility at the University of Rhode Island (URI)'s Narragansett Bay Campus in Narragansett, RI.. 23

Figure 2. Mean percent Spartina alterniflora stem density change from initial measurements per treatment, \pm 1 standard error. The initial average stem values per core (prior to algal additions) were as follows. Control: 31.2, Fucus 6: 31.6, Ulva 6: 31, Mix 3: 32.8, and Mix 6: 35. Measurement were taken every 4 weeks through duration of experiment. .24

Figure 3. Mean percent change in Spartina alterniflora stem height from initial height per treatment, \pm 1 standard error. The initial average stem height values (prior to algal additions) were as follows. Control: $41.6 \mathrm{~cm}$, Fucus 6: 39.4cm, Ulva 6: 39.1 cm, Mix 3: 39.4cm, and Mix 6: $38.3 \mathrm{~cm}$. Measurement were taken every 4 weeks through duration of experiment. 25

Figure 4. Spartina alterniflora stem percent nitrogen content per treatment, \pm standard error. Measurements were taken every 4 weeks throughput the duration of the experiment. Week 0 represents the percent nitrogen content before macroalgal addition 
Figure 5. Mean carbon dioxide fluxes per treatment, \pm standard error.

Figure 6. Mean methane fluxes per treatment, \pm 1 standard error. .28

\section{Chapter 2}

Figure 1. Mean Spartina alterniflora stem density \pm 1 SE (per 26cm diameter plot)

Figure 2. Mean Spartina alterniflora percent cover $\pm 1 \mathrm{SE}$ (per $26 \mathrm{~cm}$ diameter plot)

Red line represents values before the runnels were constructed .61

Figure 3. Mean Spartina patens percent cover $+1 \mathrm{SE}$ (per $26 \mathrm{~cm}$ diameter plot). Red

line represents values before the runnels were constructed .62

Figure 4. Mean percent bare $\pm 1 \mathrm{SE}$ (per $26 \mathrm{~cm}$ diameter plot). Red line represents unvegetated areas before the runnels were constructed

Figure 5. Mean belowground biomass per core $\pm 1 \mathrm{SE}$ 64

Figure 6. Mean belowground percent organic matter $\pm 1 \mathrm{SE}$

Figure 7. Mean carbon dioxide fluxes per treatment \pm 1 SE. Sediment Enhancement does not have error bars or values if it did not produce significant fluxes at time of collection $\left(\mathrm{R}^{2}<0.9\right)$ 66

\section{Chapter 3}

Figure 1. Describes agencies' roles in the initial assessment and proposal development of the Q-SEAM project. .88

Figure 2. Describes the main goals of the project stakeholders and the derived overall

project mission.

Figure 3. A. Signage placed at Quonnie restoration site. B. Designated recreational area for civilians at the Quonnie restoration site. C \& D. Quonnie salt marsh planting 


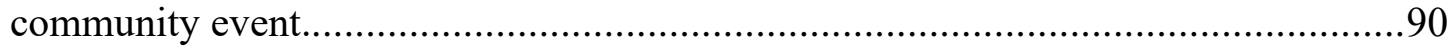




\title{
CHAPTER 1
}

\section{GREENHOUSE GAS RESPONSE AND SPARTINA ALTERNIFLORA RESILIENCE} TO MACROALGAL EXPOSURE

\author{
Danielle C. Perry ${ }^{1}$ Serena Moseman-Valtierra ${ }^{2}$ and Carol S Thornber ${ }^{1}$ \\ ${ }^{1}$ Natural Resources Science, University of Rhode Island, Kingston, RI USA 02881 \\ ${ }^{2}$ Biological Sciences, University of Rhode Island, Kingston, RI USA 02881
}

Manuscript published in Aquatic Botany Volume 162 


\begin{abstract}
Climate change can alter salt marsh plant communities and their associated carbon flux dynamics via several mechanisms. Due to warming waters and sea level rise, macroalgal wrack accumulation rates in salt marshes are expected to increase. The smothering and shading effects of macroalgal wrack can have adverse effects on salt marsh vegetation. Most studies have focused on the impacts of high density accumulation or future accumulation projections, but the impacts of current accumulations of macroalgae on Spartina alterniflora (S. alterniflora) are unclear. We investigated how current, relatively low density ephemeral (Ulva spp.) and perennial (Fucus spp.) algal wrack coverage impacts S. alterniflora survival and associated greenhouse gas fluxes. We created mesocosms with $S$. alterniflora-vegetated soil cores using a 2 X 2 factorial design with Fucus and Ulva present or absent. After one month, S. alterniflora cores with Ulva (but no Fucus) had a significantly lower stem density, but they later recovered, attesting to S. alterniflora's resilience to low density macroalgal coverage. Our results also suggest that Fucus can alter the interaction between Ulva and S. alterniflora by potentially mitigating Ulva's impacts. Macroalgal presence did not significantly influence greenhouse gas fluxes, which suggests the low density exposure is not altering the salt marsh carbon flux dynamics.
\end{abstract}




\section{Introduction}

Salt marsh habitats serve as carbon sinks due to slow soil decomposition processes and carbon dioxide uptake by vegetation (Reddy and DeLaune 2008). However, they are increasingly threatened due to anthropogenic factors including climate change (causing rapid sea level rise, increased water temperatures, changing precipitation patterns, and other factors), eutrophication, and coastal development (McLeod et al., 2011; Pennings et al., 2002; Watson et al., 2016, 2014). Marsh loss can reduce storm protection, nutrient sequestration and filtration, water quality maintenance, as well as habitat for fish, shellfish, and wildlife (van de Koppel et al., 2005; Valiela and Fox 2008; McLeod et al., 2011; Wigand et al., 2017).

Macroalgae have an under-recognized but significant presence in salt marshes worldwide. Brown macroalgae, such as the fucoids Fucus and Ascophyllum, are perennial, can originate in salt marshes, and are often layered on the sediment surface or attached to hard substrate. They are slow-growing, branched algae that can survive for several years (Tyrrell et al., 2015). Overall, perennial fucoids play a beneficial role in salt marsh environments by increasing sedimentation and accretion rates, although they can inhibit Spartina alterniflora (S. alterniflora) seedling colonization (Tyrrell et al. 2015).

In contrast, bloom-forming algae are ephemeral, and commonly occur (mostly in the summer months) in salt marsh environments, with shallow, calm waters and high nutrient inputs (Newton and Thornber 2012; Lyons et al. 2014). They also serve as a food source and shelter for salt marsh invertebrate species, and release nutrients upon decomposition into the salt marsh environment. Blooms typically consist of 
'opportunistic,' ephemeral macroalgal genera with high nutrient uptake rates and rapid growth and decomposition rates, such as Ulva, Ceramium, and Gracilaria (Peckol and Rivers, 1995; Scanlan et al., 2007). These algae take advantage of seasonally warm temperatures and light that allow for rapid growth (Luo et al. 2012). As a result, bloom-forming algae are prolific during the summer months, which is enhanced by coastal eutrophication. Large accumulations of bloom-forming algae often inundate salt marshes (via tidal action) creating wrack disturbance and shading on salt marsh vegetation (Wasson et al., 2017). Due to their differences in life span and morphology, we predicted that the environmental impacts of bloom-forming algae and fucoids on salt marsh plants will vary.

As macroalgal blooms have become more abundant during the summer months, macroalgal wrack accumulation has also become a prevalent problem within salt marsh environments (Newton and Thornber 2012; Wasson et al. 2017). Previous studies have shown that plant wrack debris, formed from species such as $S$. alterniflora, Phragmites australis, and seagrasses, can decrease S. alterniflora coverage and stem height and increase bare areas within salt marshes (Byer et al., 2004; Hartman et al., 1983; Macreadie et al., 2013). Wrack deposition has led to the formation of salt marsh pannes, with less dense vegetation coverage and plants with stunted growth (Hartman et al. 1983). Wasson et al. (2017) showed that coverage by dense Ulva mats lead to the decline in Salicornia stem density and formation of bare salt marsh areas, erosion, and the landward retreat of salt marsh edge boundaries. Within New England salt marshes, macroalgal mats can hinder the growth of $S$. alterniflora (Newton and Thornber 2012; Ober and Martin 2018). High Ulva 
abundance has also led to reductions in S. alterniflora above and belowground biomass and higher porewater sulfide concentrations and toxic ammonium levels in salt marsh soils (Watson et al., 2015). These accumulations often occur closest to creek banks and the water's edge, but as sea level rise occurs, macroalgae are expected to be transported further into the marsh (Wasson et al. 2017; Ober and Martin 2018). Most studies have investigated the impacts of high-density accumulation or future macroalgal projections, but the impacts of current macroalgal conditions on salt marsh vegetation are unclear.

In this study, we examined the impacts of current marsh densities of perennial brown algae, Fucus spp., and the ephemeral bloom-forming algae, Ulva spp. (Newton and Thornber 2012), on the growth, stem density, and nutrient content of vegetated cores of S. alterniflora, the dominant low marsh plant on the Atlantic coast. We also measured the carbon dioxide and methane fluxes of the vegetated soil cores to determine the impacts of macroalgal addition on greenhouse gas fluxes. We expect that Ulva, due to blade-morphology, would negatively impact stem density via smothering, but cause elevated S. alterniflora stem nitrogen content due to its rapid decomposition. By contrast, we did not expect significant impacts of Fucus on stem density or stem nitrogen content, due to its branched morphology, slow growth rate, and slow decomposition rate. By focusing on current macroalgal accumulation densities, we hope to understand the threshold of $S$. alterniflora resilience to macroalgal coverage. We interpret our results in light of a changing climate and discuss potential roles of changes in algal abundances in salt marsh decline. 


\section{Methods}

\section{MESOCOSOM DESIGN}

In June of 2016, we transplanted twenty-five S. alterniflora-vegetated soil cores (20cm diameter, $20 \mathrm{~cm}$ height) from Fox Hill Salt Marsh in Jamestown, Rhode Island to the outdoor Marine Science Research Facility at the University of Rhode Island (URI)'s Narragansett Bay Campus in Narragansett, RI. A mesocosm consisted of an individual core that was placed in an individual 125 liter translucent rectangular bin (Fig.1a, b). The mesocosms were transplanted to an open outdoor area, with complete exposure to natural outdoor conditions (e.g. ambient temperature, irradiance). During the experiment, the mean air temperature was $23^{\circ} \mathrm{C}$ (daily minimum range $6^{\circ} \mathrm{C}$ to $17^{\circ} \mathrm{C}$, maximum range $25^{\circ} \mathrm{C}$ to $36^{\circ} \mathrm{C}$ ).

To simulate natural tidal cycles, raw, unfiltered ambient temperature seawater (nutrient concentrations listed in Table 1) was pumped into the mesocosms via a manifold $(5 \mathrm{~cm}$ in diameter PVC pipes). Salinity of the seawater was measured weekly and ranged from 30.8 to 32.1 psu. Water flow was regulated by a solenoid valve (WIC 3/4" anti-corrosion salt water solenoid valve NC) and timer (GE 24-hr timer), allowing for alternating four-hour periods of inundation and draining. Six-hour tidal cycles, the semidiurnal pattern in the Northeast USA, were unattainable due to mechanical limitations in our system. To simulation natural tide conditions, the S. alterniflora stems were completely submerged at the peak of the four-hour tidal cycle (high tide) and completely drained at the end of the four-hour tidal cycle (low tide). This was regulated by the high-tide and low-tide outflow valves created for each mesocosm. EXPERIMENTAL DESIGN 
The experiment took place from June -September of 2016 during the active salt marsh growing season. The macroalgal treatment densities within this experiment represented mean low-density accumulation (recorded here as wet mass) within Rhode Island salt marshes, which refers to accumulations that occur outside of the peak growing season of July and August; high density accumulations (occurring within July and August) were $420 \mathrm{~g} / \mathrm{m}^{2}$ (Newton and Thornber 2012; Newton and Thornber 2013). Mesocosms ( $\mathrm{n}=5$ for each treatment) were set up in a $2 \times 2$ factorial design: 0 or 210 $\mathrm{g} / \mathrm{m}^{2}$ of fucoids added and 0 or $210 \mathrm{~g} / \mathrm{m}^{2}$ of Ulva. An additional five mesocosms consisting of $210 \mathrm{~g} / \mathrm{m}^{2}$ of both fucoids and Ulva were added to investigate the interaction effect of these algal types on S. alterniflora. To test for the effects of total biomass vs. species composition, an additional five mesocosms were set up consisting of $105 \mathrm{~g} / \mathrm{m}^{2}$ of both fucoids and Ulva.

Since the species composition of Fucus and Ulva wrack is variable within salt marsh environments (Fucus distichus, Fucus spiralis, Fucus vesiculosus, Ulva australis, Ulva compressa, Ulva laetevirens, and Ulva rigida), we used a mix of fucoid and/or Ulva species to best represent typical wrack cover in New England marshes (Newton and Thornber 2012). In this context, we define wrack as macroalgal deposits transported by tidal inundation (Newton and Thornber 2012; Wasson et al. 2017). In relation to our cores, the $210 \mathrm{~g} / \mathrm{m}^{2}$ corresponded to $6 \mathrm{~g}$ of added macroalgae per $20 \mathrm{~cm}$ diameter core and $105 \mathrm{~g} / \mathrm{m}^{2}$ corresponded to $3 \mathrm{~g}$ of macroalgal addition. The treatment with no algal addition will hereafter be referred as the control, $210 \mathrm{~g} / \mathrm{m}^{2}$ of Fucus addition as the Fucus 6 treatment, $210 \mathrm{~g} / \mathrm{m}^{2}$ of Ulva addition as the Ulva 6 treatment, $210 \mathrm{~g} / \mathrm{m}^{2}$ Fucus plus $210 \mathrm{~g} / \mathrm{m}^{2}$ Ulva addition as the Mix 6 treatment, and 
$105 \mathrm{~g} / \mathrm{m}^{2}$ Fucus plus $105 \mathrm{~g} / \mathrm{m}^{2}$ Ulva addition as the Mix 3 treatment. The treatments were placed in a row in the repetitive order of control, Fucus 6 treatment, Ulva 6 treatment, Mix 3 treatment, and Mix 6 treatment. All measurements were taken in this order.

Every two weeks for the duration of the experiment, to account for rapid Ulva decomposition and to simulate macroalgal Ulva spp. bloom deposition, Ulva (105 or $210 \mathrm{~g} / \mathrm{m}^{2}$ depending upon the treatment) was applied to the mesocosms (Conover et al., 2016). For all fucoid treatments, mesocosms containing fucoids were checked every two weeks to ensure the allotted amount remained on the cores, and additional fucoids were added as needed to maintain treatment densities. The macroalgae were spread at the base and top of the S. alterniflora stems to simulate natural conditions in the field, since natural tidal deposition is not uniform. Although the consistency of algal coverage can be variable in a marsh environment, Wasson et al (2017) found that macroalgal coverage persisted over multiple months. Thus, we placed a mesh (netting mesh $\sim 4 \mathrm{~mm}$ ) around each core, including controls, to prevent algae from leaving the mesocosm during water drainage.

\section{STEM DENSITY AND GROWTH MEASUREMENTS}

Each month, we measured the mean shoot height (taken from 3 random placements within each mesocosm) and stem density (total number of shoots per mesocosm). We documented the percent change from initial height measurements to represent stem growth as well as the percent change in initial stem density to represent stem density changes over time. We used the following formula to calculate percent change from initial measure: 
\{Monthly stem measure (height or density)/ Initial stem measure (height or density) $1\}^{*} 100$

At the end of the experiment, the belowground biomass was extracted from each core. The belowground biomass was washed of sediment, dried at $30^{\circ} \mathrm{C}$ for 3 days, and then weighed.

\section{NUTRIENT ANALYSIS: STEM TISSUE AND POREWATER}

Each month, we measured \% carbon, hydrogen, and nitrogen $(\mathrm{CHN})$ content of S. alterniflora shoot tissues. For $\mathrm{CHN}$ analysis, a stem tissue sample (a piece of a plant stem from three haphazardly selected S. alterniflora stems) was removed per mesocosm ( $\sim 8 \mathrm{mg}$ dry weight per treatment), dried at $30^{\circ} \mathrm{C}$ for 3 days, ground with a mortar and pestle, and then analyzed via mass spectrometry (Elemental Combustion System CHNS-O, ESC 4010 Model NC2100). The stem pieces used for the CHN analysis were removed of algae before processing.

A $20 \mathrm{~mL}$ porewater sample was collected from each core using Rhizon samplers (https://www.rhizosphere.com/rhizons) and filtered with $0.2 \mu \mathrm{m}$ PES filters (EMD Millipore ${ }^{\mathrm{TM}}$ Millex ${ }^{\mathrm{TM}}$ Nonsterile Syringe Filters with PE Housing-PES, EMD Millipore $^{\mathrm{TM}}$ SLGP033NS). After filtration, the samples were placed into a freezer before nutrient analysis (completed by the URI Marine Science Research Facility). Each sample was analyzed for nitrite, nitrate, nitrite+nitrate, phosphate, and ammonium concentrations.

\section{GREENHOUSE GAS FLUX MEASUREMENTS}

Greenhouse gas (GHG) fluxes (carbon dioxide and methane) of each mesocom were measured every two weeks from June to September. Measurements were taken 
between 9:00 AM and 3:00 PM on clear days to optimize on light availability. The average light intensity ranged from 15,560 to $30,111 \mathrm{lum} / \mathrm{m}^{2}$. Carbon dioxide $\left(\mathrm{CO}_{2}\right)$ and methane $\left(\mathrm{CH}_{4}\right)$ fluxes of the mesocosm were measured using a cavity-ring down spectrometer (CRDS) (Model G2508, Picarro Inc., Santa Clara, California, USA). CRDS analyzer sampling methods were based on methodology described in Martin and Moseman-Valtierra (2015). Before GHG flux measurements took place, each core was transferred intact into in a 19 liter bucket. A polyether foam ring was secured over the vegetation (without disturbing the plants) and positioned to seal the top of the bucket for chamber placement. Due to plant height, the vegetation was above the bucket opening, which ensured that light availability was optimized for the plants. A transparent polycarbonate chamber $(41 \mathrm{~cm}$ tall $\times 27 \mathrm{~cm}$ diameter) was then placed over the foam ring to create a gas tight seal (as described in Martin and MosemanValtierra 2015). The chamber was connected to the CRDS via a vacuum pump and tubing $(0.8 \mathrm{~mm}$ in diameter). Two battery powered fans were installed within the chamber to homogenize the air. Chamber deployments were maintained for each mesocosm for 4 minutes. A temperature logger (Hobo, Bourne, MA) was mounted within the chamber, recording the temperature and luminosity every 10 seconds during this period.

Gas fluxes were calculated from linear rates of change in gas emission concentrations (ppm) over time using the Ideal Gas Law (as described in Martin and Moseman-Valtierra 2015). Positive fluxes were defined as those in which gas concentrations increased over time within the chamber, representing emission from the vegetated soil core surface to atmosphere. Negative fluxes are defined as those in 
which gas concentrations decreased over time, representing net uptake from the atmosphere by the vegetated soil core (Moseman-Valtierra et al., 2016).

\section{STATISTICAL ANALYSIS}

Two-Way ANOVAs were used to assess differences among treatments and sampling dates for S. alterniflora shoot density, height, stem nutrient content, and porewater nutrient. A One-Way ANOVA was used to assess differences in belowground biomass among treatments. Repeated measures ANOVAs using JMP v.12 (www.jmp.com) were used to assess differences in $\mathrm{CO}_{2}$ and $\mathrm{CH}_{4}$ fluxes among algal treatments. When statistical models found significant effects, Tukey's HSD tests were performed. Data were tested for normality and homogeneity of variance and were transformed when appropriate (Underwood 1997).

\section{Results}

\section{STEM DENSITY AND GROWTH MEASUREMENTS}

There was not a significant difference in core stem density at the start of the experiment (prior to algal additions). After the first four weeks, S. alterniflora plants under the Ulva 6 treatment had significantly lower stem density compared to all other treatments $\left(\mathrm{F}_{4,60}=4.37, \mathrm{p}=0.0036\right)$, which represented an initial $45 \%$ decrease $($ Fig. 2). Stem density in the Ulva 6 treatment increased in the subsequent weeks and reached similar measurements by the end of the experiment, but the stem increase was due to the growth of new stems rather than the recovery of original stems. There were no other significant responses of stem density across the other treatments. There was also no significant difference in stem growth among treatments $\left(F_{4,60}=0.6935\right.$, $\mathrm{p}=0.5994$; Fig. 3). There no significant difference in belowground biomass as well 
$\left(\mathrm{F}_{4,20}=0.9545, \mathrm{p}=0.4537\right)$.

\section{NUTRIENT ANALYSIS: STEM TISSUE AND POREWATER}

There was a significant increase in nitrogen content of the Ulva 6 treatment from the initial measurement (before macroalgal addition) to 4 weeks (Fig. 4; Table 3). After 4 weeks of macroalgal coverage, the percent nitrogen of S. alterniflora in the Ulva 6 treatment was significantly higher than the control and Mix 3 treatment (overall model: treatment: $F_{4,77}=16.50, p<0.0001$; time: $F_{3,77}=64.10, p<0.0001$; treatment $\mathrm{x}$ time $\mathrm{F}_{12,77}=44.86, \mathrm{p}<0.0001$; Fig. 4). Also at 4 weeks, the percent nitrogen content of S. alterniflora stems in the Mix 3 treatment was significantly higher than the control, Fucus, and Mix 6 treatments (Tukey post-hoc, p<0.05). However, after 8 weeks, the S. alterniflora percent nitrogen content in the Ulva 6 treatment was not significantly different from the control or the Mix 3 treatments, and was significantly lower than Fucus 6 and Mix 6 treatments (Tukey post-hoc, p<0.05). After 12 weeks, percent nitrogen content for S. alterniflora tissues in the Ulva 6 and control treatments was significantly lower than the Mix 3 and Mix 6 treatments (Tukey post-hoc, $\mathrm{p}<0.05$ ). At 8 and 12 weeks, the control had significantly lower $S$. alterniflora stem nutrient content than the Fucus treatment.

There were not significant differences among treatments in porewater nutrient content, but July porewater nitrite concentrations were significantly lower than August and September (Table 2; Tukey post-hoc, $\mathrm{p}<0.05$ ).

\section{GREENHOUSE GAS FLUX MEASUREMENTS}

There was a trend of net $\mathrm{CO}_{2}$ emission within the Ulva 6, Mix 3 and Mix 6 treatment and net $\mathrm{CO}_{2}$ uptake within the control and Fucus 6 treatments (Fig. 5), 
although the differences were not statistically significant $\left(\mathrm{F}_{4,20}=0.75, \mathrm{p}=0.57\right)$. The greatest $\mathrm{CO}_{2}$ fluxes were seen in August at the peak of the growing season $\left(\mathrm{F}_{4,17}=\right.$ $7.65, \mathrm{p}=0.001)$ with no significant interaction $\left(\mathrm{F}_{4,20}=1.70, \mathrm{p}=0.19\right)$.

Methane fluxes were not significantly different among treatments $\left(\mathrm{F}_{4,20}=1.62\right.$, $\mathrm{p}=0.21)\left(\right.$ Fig. 6). The treatments containing Ulva showed a trend of higher $\mathrm{CH}_{4}$ fluxes than the treatments without Ulva (Fucus 6 and control) (Fig. 6). There was a significant difference among months, where the August measurements (peak growing season) were significantly higher than June measurements $\left(F_{1.7,34.3}=5.87, p=0.0088\right)$ with no significant interaction $\left(\mathrm{F}_{6.8,34.3}=0.71, \mathrm{p}=0.66\right)$.

\section{Discussion}

\section{STEM DENSITY AND GROWTH}

Under the relatively low-density macroalgal accumulation studied in our experiment, we found that S. alterniflora stem density in our Ulva 6 treatment was initially negatively impacted, but later recovered (via growth of new stems), while stem density in the other treatments was unaffected. The shading from algal mats, similar to plant wrack, can limit light penetration and smother vegetation, negatively impacting aboveground biomass, which was initially witnessed in our study by Ulva coverage (Newton and Thornber, 2013; Ström et al., 2003; van Hulzen et al., 2006). However, S. alterniflora was able to recover through the production of new stems. $S$. alerniflora demonstrated an initial stress response to coverage but showed resiliency that persisted over time. Watson et al. (2015) demonstrated that high-density algal exposure resulted in lasting negative implications on $S$. alterniflora stem density. Furthermore, S. alterniflora stem density has shown resilience to current macroalgal 
density coverage, but are not tolerant of the future projections described in Watson et al. (2015).

However, the Mix 6 treatment did not have a significant impact on $S$. alterniflora stem density, despite containing the same density of Ulva as the Ulva 6 treatment. These results suggest that there is a potential interaction between Fucus and Ulva, where Fucus may be ameliorating the negative impacts of Ulva coverage (Yates and Peckol 1993). We hypothesize that shading from Fucus is causing a faster decomposition of Ulva thus minimizing the smothering impact (Higgins et al., 2008; Chen et al., 2009). However, this relationship needs further study.

Although other studies have linked nutrient additions with increased plant growth rates (Pennings et al., 2005; McFarlin et al., 2008), there were not significant differences in S. alterniflora growth rates among treatments. By contrast, high macroalgal additions have been shown to negatively impact mean stem height (Watson et al., 2015; Wasson et al., 2017). Since our low density treatments showed similar growth patterns by the end of the experiment, it suggests $S$. alterniflora growth is not significantly influenced under these macroalgal densities.

\section{STEM AND POREWATER NUTRIENT CONTENT}

Numerous studies have found positive correlations between nutrient additions

and S. alterniflora growth rate, biomass, stem density, and photosynthetic rate (Valiela and Teal 1974; Levine et al., 1998; Pennings et al., 2005; McFarlin et al., 2008). Boyer and Fong (2005) traced nitrogen from macroalgae to plant stems, which demonstrates the influence of macroalgal exposure to plant nitrogen content. In our study, S. alterniflora in the Ulva 6 treatment had significantly higher stem percent 
nitrogen than the control after four weeks, potentially due to nitrogen released from rapid Ulva decomposition (Castaldelli et al., 2003; Viaroli et al., 1992). Other nutrient addition studies have demonstrated similar patterns (Newton and Thornber 2013); McFarlin et al. (2008) found an increase in S. alterniflora nitrogen content with the addition of nutrients as well as an increase in cover, height, and biomass. $S$. alterniflora may also allocate nutrients to roots and rhizomes rather than to the stems, which could explain the decrease in stem nitrogen content of the Ulva 6 treatment during the subsequent weeks (Hopkinson and Schubauer, 1984; Newton and Thornber, 2013). At 8 and 12 weeks, the control had significantly lower S. alterniflora stem nutrient content than the Fucus 6 treatment, which suggests S. alterniflora is absorbing nutrients released from Fucus (Hunter, 1976; Nielsen et al., 2007). However, since there was not a significant difference in stem growth it suggests that the supplied nutrients from macroalgal decomposition at these current densities are not sufficient to enhance growth.

In our experiment, the impact of Ulva coverage and nutrient addition was clear due to the significant increase in S. alterniflora nitrogen content seen in the Ulva 6 treatment from the initial measurement (before Ulva addition) to 4 weeks. The results also show higher percent nitrogen seen in the Ulva 6 treatment occurring during the same time frame as the stem density decline, which suggests that higher stem nitrogen content may be due to less competition for nutrients among S. alterniflora stems. In the subsequent weeks, stem nitrogen content decreased when the stem density increased within the Ulva 6 treatment, which further supports this argument and suggests that nutrients were potentially allocated for new stem growth (Davis et al., 
2017). The results and relationship between the Mix 3, Mix 6 treatment, and the control also suggest that there is an interaction between Fucus and Ulva that is impacting S. alterniflora stem nutrient content, but this relationship needs further investigation (Fig. 4, Table 3).

However, at four weeks we did not find similar high values in S. alterniflora stem nitrogen content as the Ulva 6 treatment in our other algal addition treatments including the Mix 6 treatment (twice as much algae as the Ulva 6 treatment). Also at four weeks, the S. alterniflora of the Mix 6 treatment (contained double the amount of Fucus as Mix 3 treatment) had significantly lower stem nitrogen content than the Mix 3. This suggests that Fucus may be impacting the effects of Ulva coverage, creating a barrier between Ulva and S. alterniflora and potentially absorbing the nutrients released in Ulva decomposition leading to less consumption of nutrients by $S$. alterniflora (Yates and Peckol 1993). It is also possible that some nutrients are being flushed from the system as the water is drained during low tide.

The porewater analysis did not show a significant impact of algae on porewater nutrient concentration, which suggests that these nutrients may be exiting the system via drainage or absorbed and utilized by S. alterniflora (Howes and Goehringer, 1994; Johnson et al., 2016). The relatively low algal densities used in this experiment may not be sufficient to instigate changes in porewater nutrient content as well. Watson et al. (2015) found that porewater nutrient content after high-density algal additions result in significantly higher nutrient concentration. These results suggest that macroalgal accumulation does not have an automatic effect on porewater, but the impact may be dependent on macroalgal density. 


\section{GREENHOUSE GAS FLUXES}

In this study, we are examining the impact that macroalgal accumulation has on net greenhouse gas fluxes within a salt marsh environment to determine whether macroalgal coverage influences salt marsh carbon flux dynamics. Due to slow decomposition processes and high rates of carbon dioxide uptake by vegetation, salt marshes are important carbon sinks (Reddy and DeLaune 2010). Salt marshes produce a negligible amount of methane due to the competitive interaction of sulfate reducing bacteria and methanogens (Reddy and DeLaune 2010; Poffenbarger et al. 2011). However, nutrient enrichment (via macroalgal decomposition) can enhance carbon dioxide and methane production in salt marshes potentially creating a carbon source (Moseman-Valtierra 2013; Chmura et al., 2016). The decomposition of organic matter, including macroalgae, can supply nutrients needed for microorganisms, which enhances the generation of carbon dioxide (via respiration; Reddy and DeLaune 2010) and methane (via methanogenesis; Poffenbarger et al. 2011). In addition, soil oxygen is depleted during decomposition, thus exacerbating anoxic conditions creating a more hospitable environment for methanogens and anaerobic bacteria, which can lead to the greater fluxes; these patterns were seen in our experiment (Valiela et al. 1997; Reddy and DeLaune 2010). Watson et al. (2015) found that high-density Ulva accumulation resulted in significantly higher carbon dioxide fluxes. These trends were observed under our low-density algal treatments (Fig. 5, Fig 6.), but were not significant. Our results suggest that these relatively low-density yet current macroalgal accumulations do not show to significantly impact a salt marsh's carbon flux dynamics. 
Previous studies have demonstrated the threat of Ulva coverage on salt marsh vegetation (Watson et al., 2015; Wasson et al., 2017). The blade morphology of Ulva may create a barrier between the soil-atmospheric interface, yielding a more anoxic environment that is suitable for anaerobic bacterial activity (Reddy and DeLaune 2010). Increased plant and soil respiration due to plant stress caused by macroalgal smothering, macroalgal respiration, and an increase in resource availability from plant and macroalgal detritus could be responsible for the trend of greater carbon dioxide and methane fluxes seen in the treatments containing Ulva (Flexas et al., 2006; Neubauer, 2010; Ryan, 1991). The Fucus treatment showed similar fluxes to the control (negative carbon dioxide flux and lower methane flux), which could be explained by its branched morphology and slow decomposition that minimizes shading stress and nutrient release. Further investigation is warranted to see if this pattern remains in higher density Fucus accumulation.

Macroalgal coverage at current densities showed patterns of increased carbon dioxide and methane emissions relative to the control, but did not result in lasting negative effects on S. alterniflora, indicating S. alterniflora resiliency to macroalgal coverage at these densities. However, negative implications of macroalgal coverage (initial stem density decline, trends of higher greenhouse gas fluxes) are manifesting under low-density accumulations. Furthermore, the impacts of higher density accumulation (420 g/m²; Newton and Thornber 2012) may result in negative implications on $S$. alterniflora survival and significantly higher greenhouse gas emissions (e.g. Watson et al., 2015; Wasson et al., 2017). As macroalgal densities 
increase with climate change progression, they may significantly influence vegetation survival and greenhouse gas production (Doney et al., 2012; Sinha et al., 2017).

\section{Acknowledgements}

Funding: This research has been supported by the National Science Foundation Established Program to Simulate Competitive Research (EPSCoR) Cooperative Agreement [grant numbers \#EPS-1004057 and \#OIA-1655221]; National Science

Foundation Graduate Research Fellowship (grant number DGE-1747454); University of Rhode Island (URI)'s Enhancement of Graduate Research Award; and the Northeast Algal Society Wilce Presentation Award (awarded to Danielle Perry).

This material is based upon work conducted at the Rhode Island NSF EPSCoR Marine Life Science Center. We would like to thank E. Baker, G. Ober, and URI Narragansett Bay Marine Science Research Facility for support and aide in experimental set up and design, A. Barry and N. Castro for field and laboratory assistance, and C. Wigand, R. Martin, A. Humphries, and two anonymous reviewers for manuscript advice. T. Rynearson and the URI Graduate School of Oceanography supplied data from the URI Narragansett Bay Long-Term Plankton Time Series. 
Table 1. Ambient seawater average nutrient content. These are the mean values $( \pm 1$ standard error) from June-September 2016, the duration of the experiment. Data is obtained from Narragansett Bay Long-Term Plankton Time Series at https://web.uri.edu/plankton/data/ at Narragansett Bay Station Two

\begin{tabular}{|ll|}
\hline Nutrient & Average Value $(\mu \mathrm{mol})+/$ - Standard Error \\
Dissolved Inorganic Phosphorous & $1.38 \pm 0.38$ \\
Nitrate+Nitrite & $0.60 \pm 0.16$ \\
Nitrate & $0.069 \pm 0.11$ \\
Nitrite & $0.13 \pm 0.027$ \\
Dissolved Inorganic Nitrogen & $0.62 \pm 0.14$ \\
\hline
\end{tabular}


Table 2. Statistical result of Spartina alterniflora core porewater analysis

\begin{tabular}{|c|c|c|}
\hline Nutrient & $\begin{array}{l}\text { Average }(\mu \mathrm{mol})+/- \\
\text { Standard Error }\end{array}$ & $\begin{array}{l}\text { Repeated Measures } \\
\text { ANOVAs results }\end{array}$ \\
\hline Ammonium & $\begin{array}{l}\text { Control: } 13.12 \pm 3.28 \\
\text { Fucus 6: } 9.35 \pm 3.63 \\
\text { Ulva 6: } 13.13 \pm 2.98 \\
\text { Mix 3: } 22.51+3.59 \\
\text { Mix 6: } 13.33+3.28\end{array}$ & Model: $\mathrm{F}_{12,31}=1.70, \mathrm{p}=0.12$ \\
\hline Nitrite & $\begin{array}{l}\text { Control: } 0.44+0.042 \\
\text { Fucus 6: } 0.23+0.047 \\
\text { Ulva 6: } 0.35+0.038 \\
\text { Mix 3: } 0.44+0.046 \\
\text { Mix 6: } 0.43 \pm 0.042\end{array}$ & $\begin{array}{l}\text { Model: } F_{12,31}=9.60, \\
p<0.0001 \\
\text { Treatment: } F_{2,31}=1.58, \\
p=0.22 \\
\text { Time: } F_{1,31}=49.71, p<0.0001 \\
\text { Treatment*Time: } F_{6,31}=4.10, \\
p=0.0038\end{array}$ \\
\hline Nitrate & $\begin{array}{l}\text { Control: } 3.20 \pm 0.51 \\
\text { Fucus } 62.10 \pm 0.56 \\
\text { Ulva 6: } 1.49 \pm 0.46 \\
\text { Mix 3: } 2.39 \pm 0.56 \\
\text { Mix 6: } 1.75 \pm 0.51\end{array}$ & Model: $\mathrm{F}_{12,31}=1.33, \mathrm{p}=0.25$ \\
\hline Nitrite + Nitrate & $\begin{array}{l}\text { Control: } 3.63 \pm 0.53 \\
\text { Fucus 6: } 2.34+0.59 \\
\text { Ulva 6: } 1.84+0.48 \\
\text { Mix 3: } 2.83 \pm 0.58 \\
\text { Mix 6: } 2.18 \pm 0.53\end{array}$ & Model: $\mathrm{F}_{12,31}=1.22, \mathrm{p}=0.31$ \\
\hline Phosphate & $\begin{array}{l}\text { Control: } 1.92 \pm 0.46 \\
\text { Fucus 6: } 1.28 \pm 0.51 \\
\text { Ulva 6: } 1.83 \pm 0.42 \\
\text { Mix 3: } 2.76 \pm 0.50 \\
\text { Mix 6: } 1.74+0.46\end{array}$ & Model: $\mathrm{F}_{12,31}=1.04, \mathrm{p}=0.44$ \\
\hline
\end{tabular}


Table 3. Tukey post hoc test results of the Spartina alterniflora stem nitrogen content analysis. Conditions not connected by same letter represent significant differences.

\begin{tabular}{|lll|}
\hline Treatment & Week & $\underline{\text { Letter }}$ \\
\hline Control & 0 & C, D \\
Control & 4 & G, H \\
Control & 8 & G, H \\
Control & 12 & D, E, F, G \\
Fucus 6 & 0 & B \\
Fucus 6 & 4 & G, H \\
Fucus 6 & 8 & C, D, E \\
Fucus 6 & 12 & C, D \\
Ulva 6 & 0 & E, F, G \\
Ulva 6 & 4 & A \\
Ulva 6 & 8 & H \\
Ulva 6 & 12 & D, E, F \\
Mix 3 & 0 & C, D \\
Mix 3 & 4 & C, D \\
Mix 3 & 8 & G, H \\
Mix 3 & 12 & B, C \\
Mix 6 & 0 & C, D \\
Mix 6 & 4 & H \\
Mix 6 & 8 & F, G, H \\
Mix 6 & 12 & B, C \\
\hline
\end{tabular}


Figure 1a. Schematic showing experimental mesocosm design, with Spartina alterniflora and varying macroalgal wrack treatments, $\mathrm{n}=5$ (left to right: control, Fucus 6, Ulva 6, Mix 3, Mix 6). The green-blade alga is Ulva and the branched alga is Fucus.

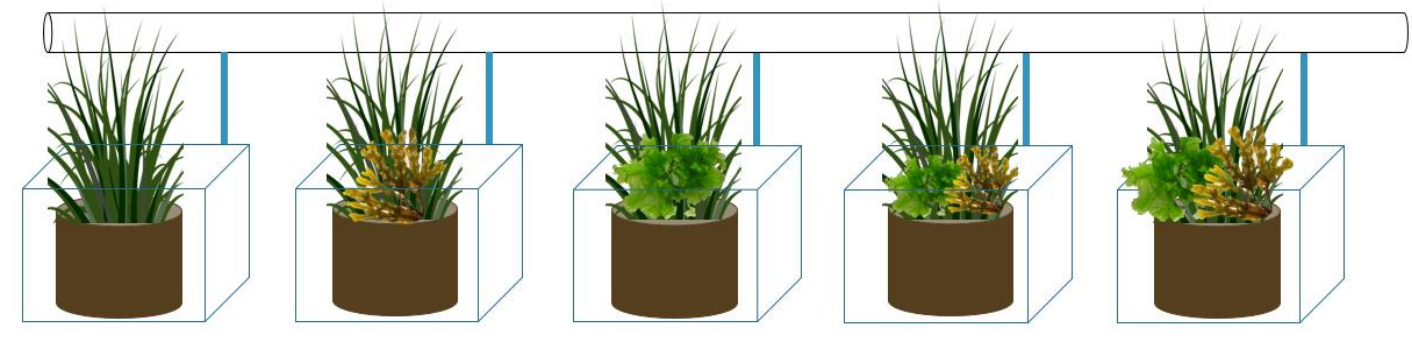

Figure 1b. Photo of experimental set up at the Marine Science Research Facility at the University of Rhode Island (URI)'s Narragansett Bay Campus in Narragansett, RI.

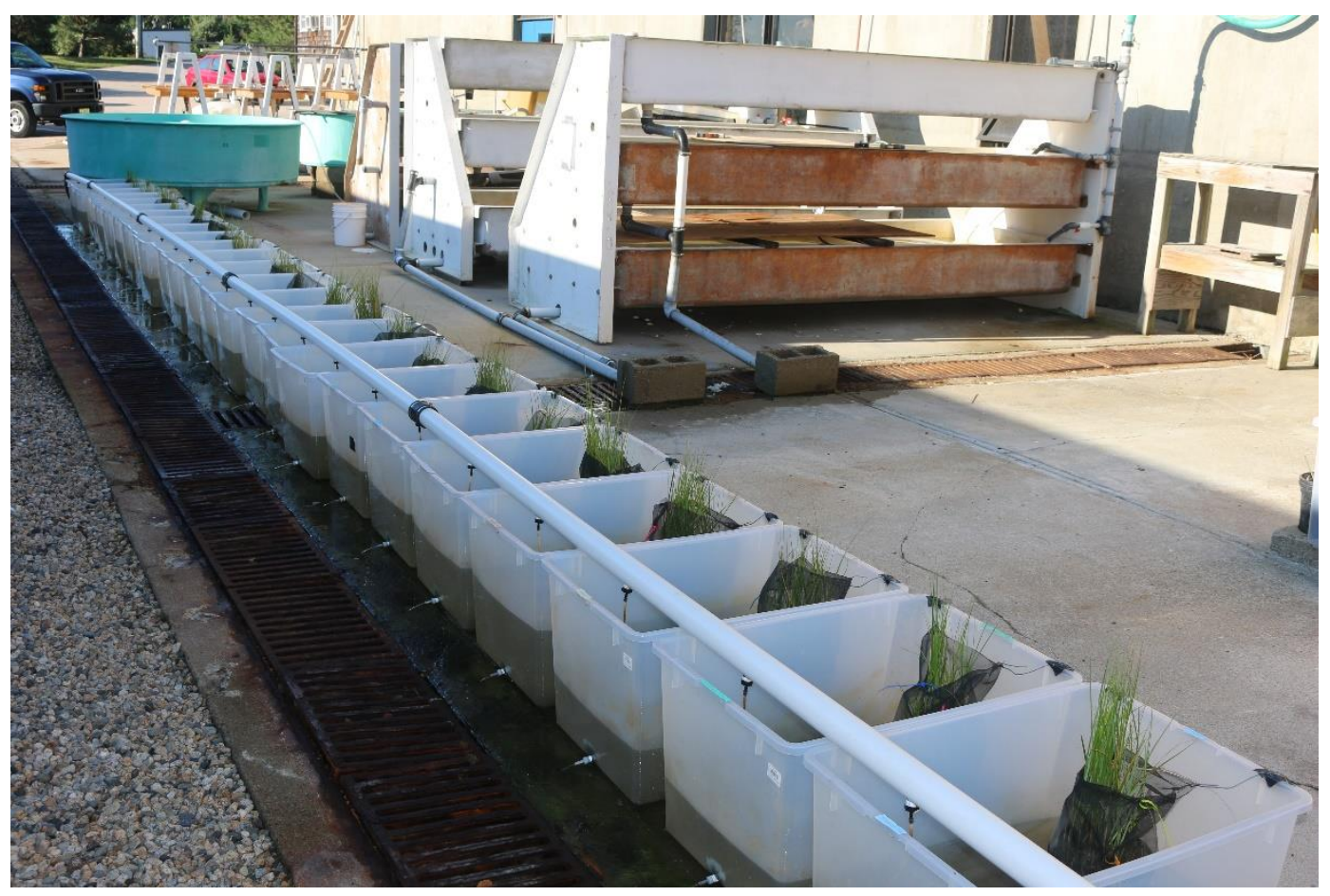


Figure 2. Mean percent Spartina alterniflora stem density change from initial measurements per treatment, \pm 1 standard error. The initial average stem values per core (prior to algal additions) were as follows. Control: 31.2, Fucus 6: 31.6, Ulva 6: 31, Mix 3: 32.8, and Mix 6: 35. Measurement were taken every 4 weeks through duration of experiment.

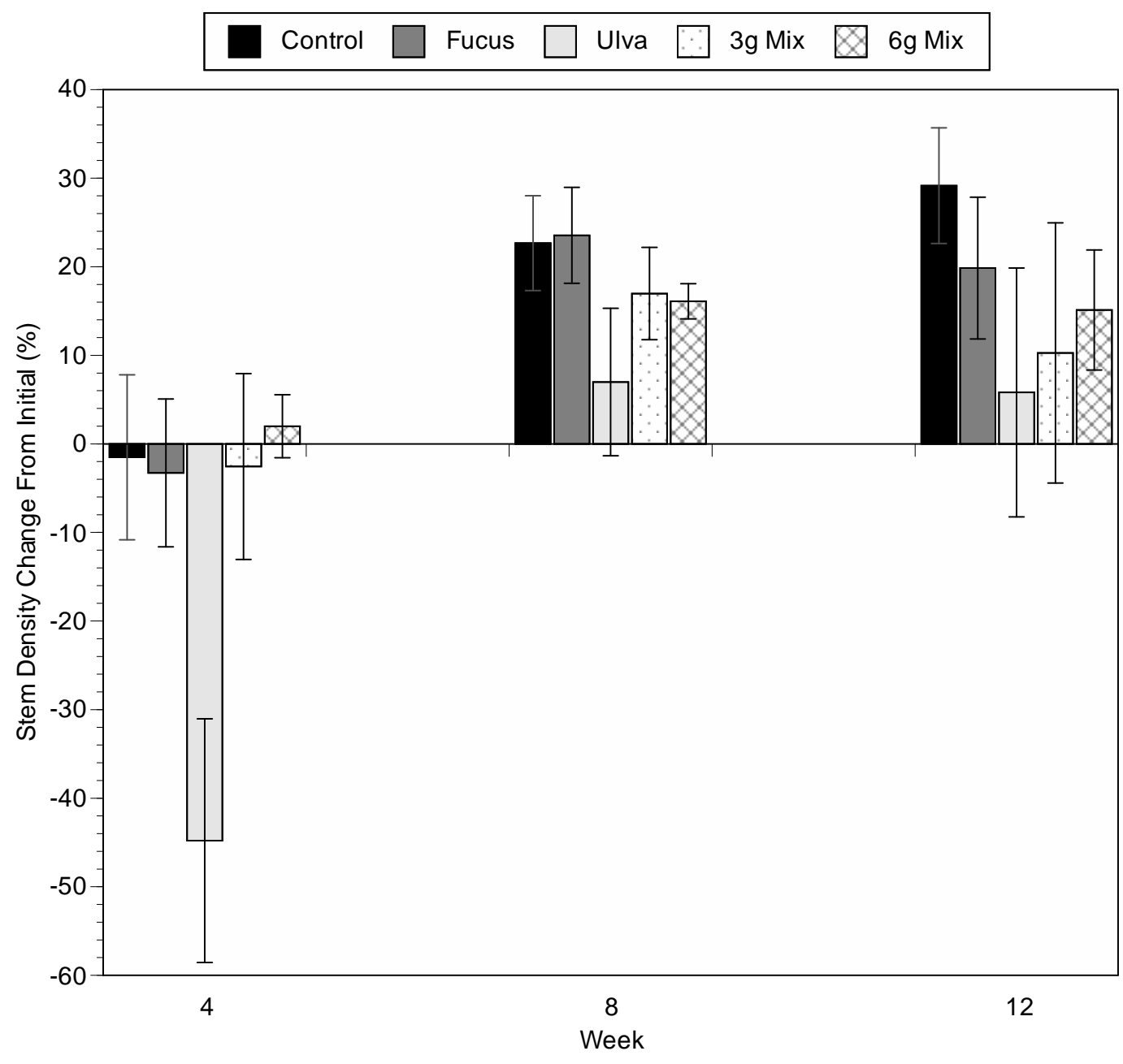


Figure 3. Mean percent change in Spartina alterniflora stem height from initial height per treatment, \pm 1 standard error. The initial average stem height values (prior to algal additions) were as follows. Control: $41.6 \mathrm{~cm}$, Fucus 6: $39.4 \mathrm{~cm}$, Ulva 6: $39.1 \mathrm{~cm}$, Mix 3: $39.4 \mathrm{~cm}$, and Mix 6: $38.3 \mathrm{~cm}$. Measurement were taken every 4 weeks through duration of experiment.

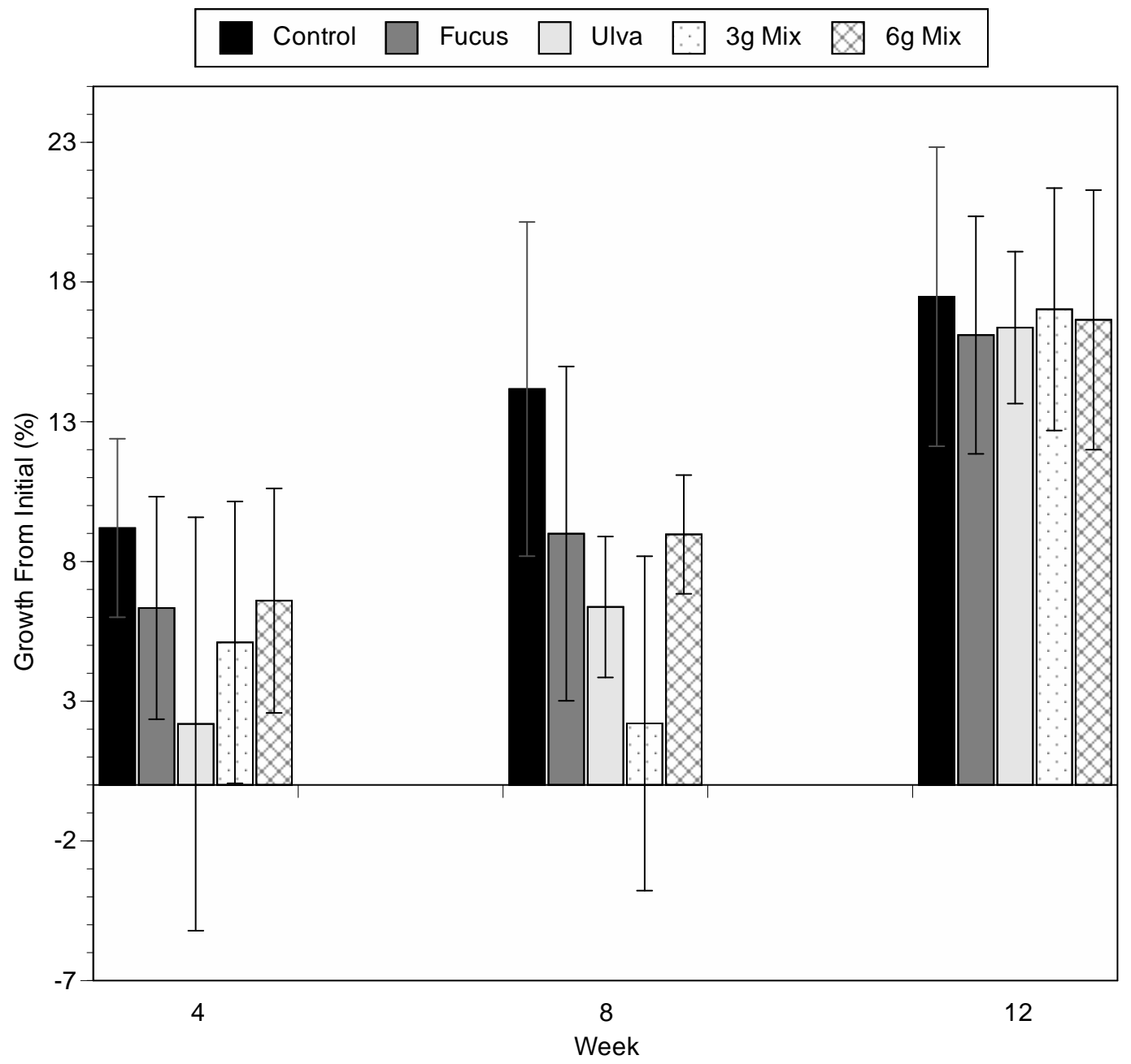


Figure 4. Spartina alterniflora stem percent nitrogen content per treatment, \pm standard error. Measurements were taken every 4 weeks throughput the duration of the experiment. Week 0 represents the percent nitrogen content before macroalgal addition.

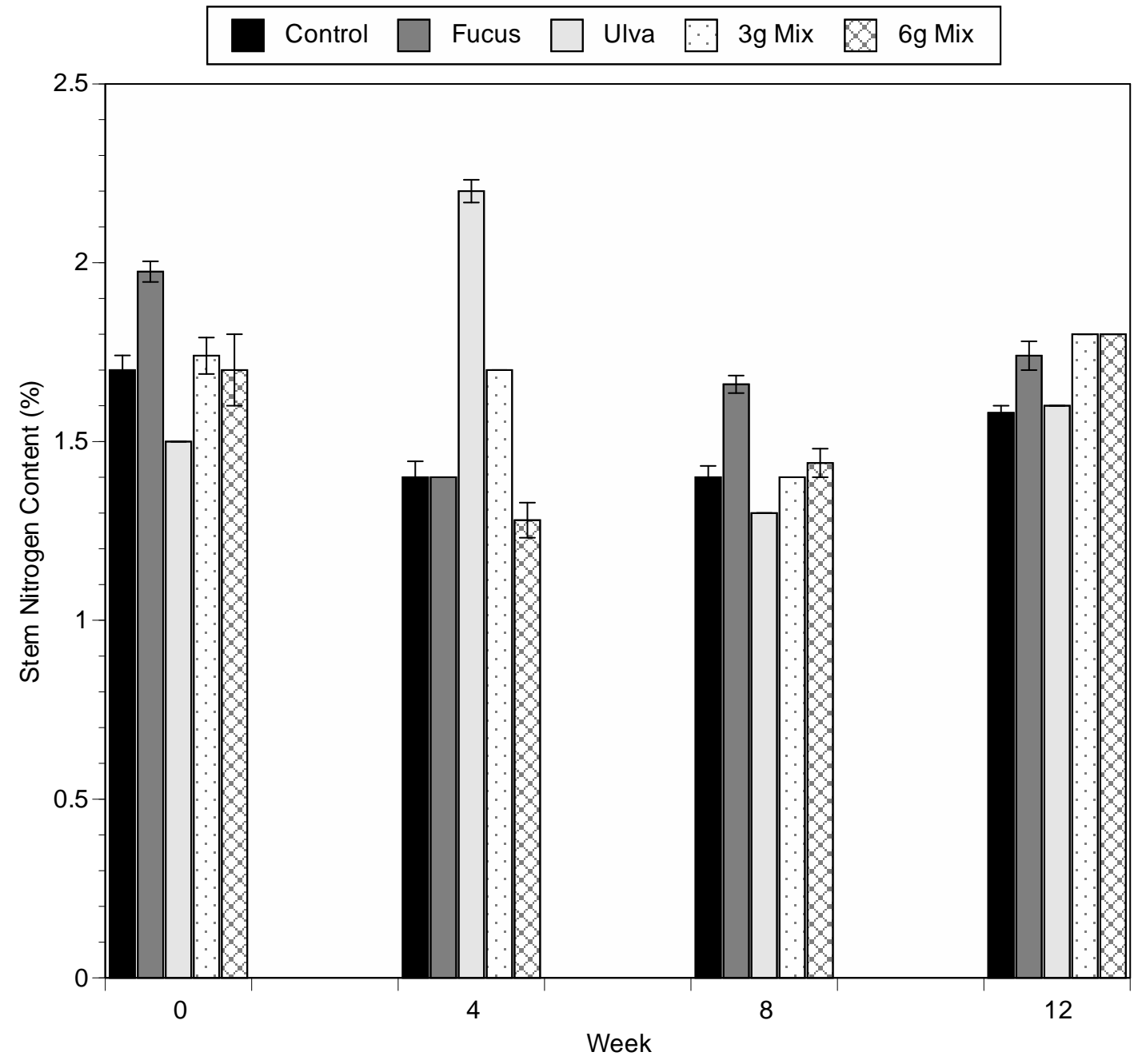


Figure 5. Mean carbon dioxide fluxes per treatment, \pm standard error.

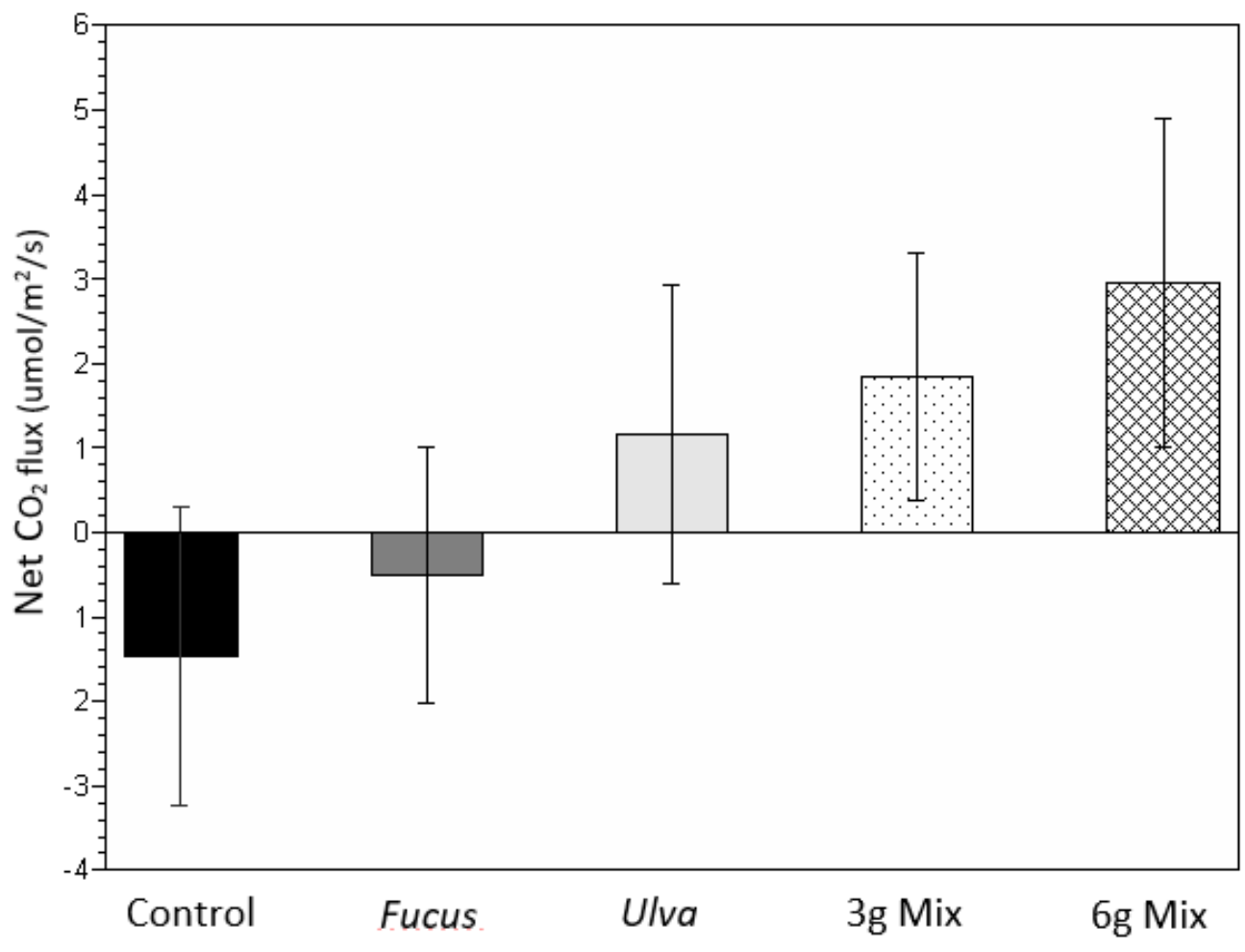


Figure 6. Mean methane fluxes per treatment, \pm 1 standard error.

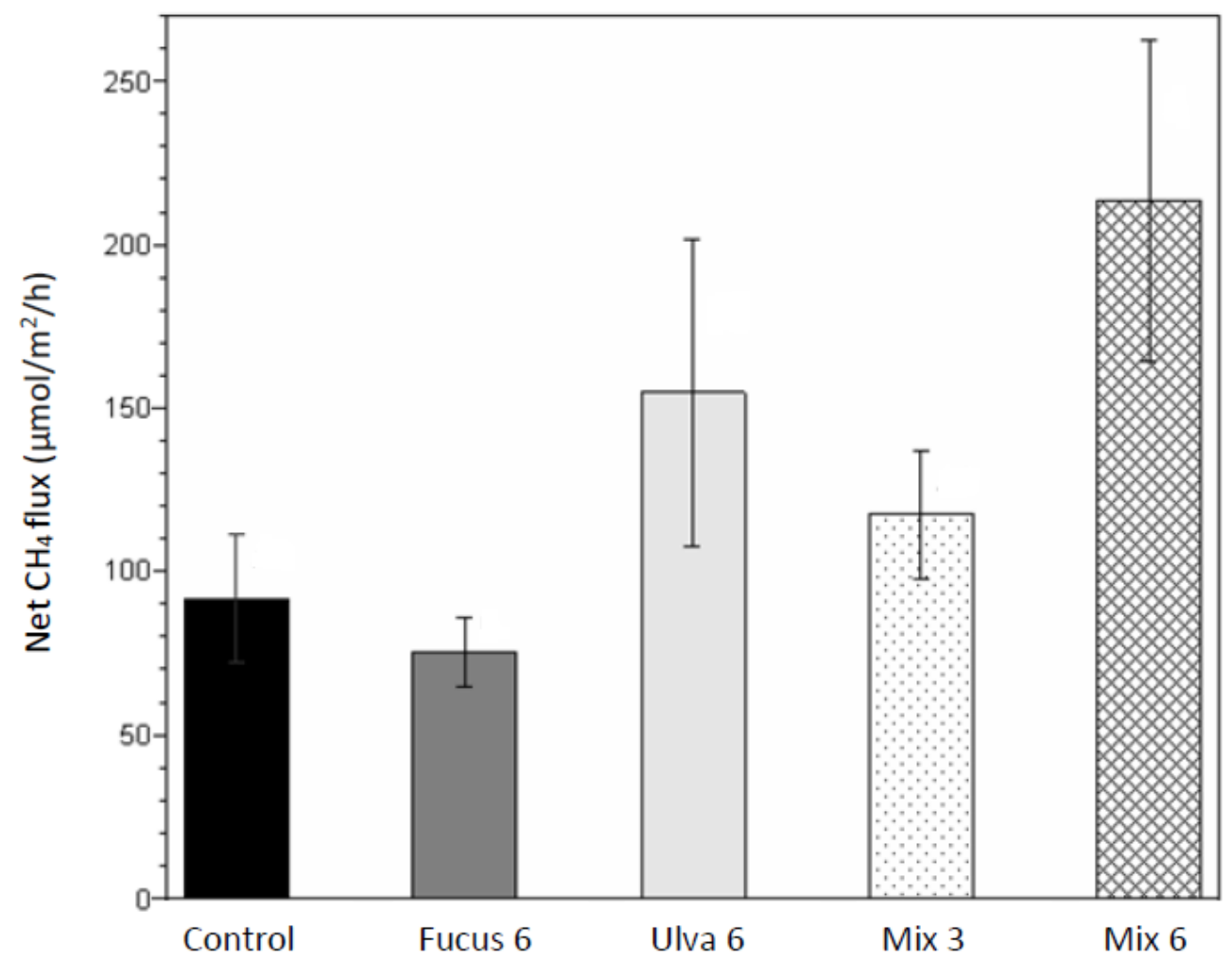




\section{References}

Alber, M., Swenson, E.M., Adamowicz, S.C., Mendelssohn, I.A., 2008. Salt Marsh Dieback: An overview of recent events in the US. Estuar. Coast. Shelf Sci. 80, 111. https://doi.org/10.1016/j.ecss.2008.08.009

Allen, J.R.L., 1990. The formation of coastal peat marshes under an upward tendency of relative sea-level. J. Geol. Soc. London. https://doi.org/10.1144/gsjgs.147.5.0743

Ashton, A.D., Donnelly, J.P., Evans, R.L., 2008. A discussion of the potential impacts of climate change on the shorelines of the Northeastern USA. Mitig. Adapt. Strateg. Glob. Chang. https://doi.org/10.1007/s11027-007-9124-3

Barbier, E.B., Hacker, S.D., Kennedy, C., Kock, E.W., Stier, A.C., Sillman, B.R., 2011. The value of estuarine and coastal ecosystem services. Ecol. Monogr. 81, 169-193. https://doi.org/10.1890/10-1510.1

Bayard, T.S., Elphick, C.S., 2011. Planning for Sea-level Rise: Quantifying Patterns of Saltmarsh Sparrow ( Ammodramus Caudacutus ) Nest Flooding Under Current Sea-level Conditions. Auk 128, 393-403. https://doi.org/10.1525/auk.2011.10178

Bertness, M.D., 1992. The ecology of a New England salt marsh. Am. Sci. 80, 260268.

Bertness, M.D., Gough, L., Shumway, S.W., 1992. Salt tolerances and the distribution of fugitive salt marsh plants. Ecology 73, 1842-1851.

https://doi.org/10.2307/1940035

Borchert, S.M., Osland, M.J., Enwright, N.M., Griffith, K.T., 2018. Coastal wetland adaptation to sea level rise: Quantifying potential for landward migration and coastal squeeze. J. Appl. Ecol. https://doi.org/10.1111/1365-2664.13169

Boyd, B.M., Sommerfield, C.K., 2016. Marsh accretion and sediment accumulation in a managed tidal wetland complex of Delaware Bay. Ecol. Eng. https://doi.org/10.1016/j.ecoleng.2016.03.045

Boyer, K.E., Fong, P., 2005. Macroalgal-mediated transfers of water column nitrogen to intertidal sediments and salt marsh plants. J. Exp. Mar. Bio. Ecol. 321, 59-69. https://doi.org/10.1016/j.jembe.2005.01.005

Breitfuss, M.J., Connolly, R.M., 2004. Consolidation and volumetric soil-water content of salt marsh soils following habitat modification for mosquito control. Wetl. Ecol. Manag. https://doi.org/10.1007/s11273-004-1783-1 
Byer, M.D., Frame, G.W., Panagakos, W., Waaijer, M., Aranbayev, Z., Michaels, Y., Stalter, R., Schreibman, M.P., 2004. Effects of wrack accumulation on Spartina alterniflora, Jamaica Bay Wildlife Refuge, New York City. Environ. Stud. 10, 183-190.

Cahoon, D.R., Lynch, J.C., Roman, C.T., Schmit, J.P., Skidds, D.E., 2019. Evaluating the Relationship Among Wetland Vertical Development, Elevation Capital, SeaLevel Rise, and Tidal Marsh Sustainability. Estuaries and Coasts. https://doi.org/10.1007/s12237-018-0448-X

Carey, J.C., Moran, S.B., Kelly, R.P., Kolker, A.S., Fulweiler, R.W., 2017. The Declining Role of Organic Matter in New England Salt Marshes. Estuaries and Coasts 40, 626-639. https://doi.org/10.1007/s12237-015-9971-1

Castaldelli, G., Welsh, D.T., Flachi, G., Zucchini, G., Colombo, G., Rossi, R., Fano, E.A., 2003. Decomposition dynamics of the bloom forming macroalga Ulva rigida $\mathrm{C}$. Agardh determined using a14C-carbon radio-tracer technique. Aquat. Bot. 75, 111-122. https://doi.org/10.1016/S0304-3770(02)00167-5

Chmura, G.L., Kellman, L., Van Ardenne, L., Guntenspergen, G.R., 2016. Greenhouse gas fluxes from salt marshes exposed to chronic nutrient enrichment. PLoS One 11. https://doi.org/10.1371/journal.pone.0149937

Conover, J., Green, L.A., Thornber, C.S., 2016. Biomass decay rates and tissue nutrient loss in bloom and non-bloom-forming macroalgal species. Estuar. Coast. Shelf Sci. 178, 58-64. https://doi.org/10.1016/j.ecss.2016.05.018

Corman, S.S., Roman, C.T., King, J.W., Appleby, P.G., 2012. Salt Marsh MosquitoControl Ditches: Sedimentation, Landscape Change, and Restoration Implications. J. Coast. Res. https://doi.org/10.2112/jcoastres-d-11-00012.1

Croft, A.L., Leonard, L.A., Alphin, T., Cahoon, L.B., Posey, M.H., 2006. The effects of thin layer sand renourishment on tidal marsh processes: Masonboro Island, North Carolina. Estuaries and Coasts. https://doi.org/10.1007/BF02786525

Crosby, S.C., Sax, D.F., Palmer, M.E., Booth, H.S., Deegan, L.A., Bertness, M.D., Leslie, H.M., 2016. Salt marsh persistence is threatened by predicted sea-level rise. Estuar. Coast. Shelf Sci. 181. https://doi.org/10.1016/j.ecss.2016.08.018

Dale, P.E., Dale, P.T., Hulsman, K., Kay, B.H., 1993. Runnelling to control saltmarsh mosquitoes: long-term efficacy and environmental impacts. J. Am. Mosq. Control Assoc.

Dale, P.E.R., 2008. Assessing impacts of habitat modification on a subtropical salt marsh: 20 Years of monitoring. Wetl. Ecol. Manag. https://doi.org/10.1007/s11273-007-9058-2 
Dale, P.E.R., Chapman, H., Brown, M.D., Ritchie, S.A., Knight, J., Kay, B.H., 2002. Does habitat modification affect oviposition by the salt marsh mosquito, Ochlerotatus vigilax (Skuse) (Diptera: Culicidae)? Aust. J. Entomol. https://doi.org/10.1046/j.1440-6055.2002.00258.x

Dale, P.E.R., Knight, J.M., 2006. Managing salt marshes for mosquito control: Impacts of runnelling, Open Marsh Water Management and grid-ditching in subtropical Australia. Wetl. Ecol. Manag. https://doi.org/10.1007/s11273-005-11132

Davis, J., Currin, C., Morris, J.T., 2017. Impacts of Fertilization and Tidal Inundation on Elevation Change in Microtidal, Low Relief Salt Marshes. Estuaries and Coasts 40, 1677-1687. https://doi.org/10.1007/s12237-017-0251-0

Delaune, R.D., Baumann, R.H., Gosselink, J.G., 1983. Relationships among vertical accretion, coastal submergence and erosion in a Louisiana Gulf Coast marsh. J. Sediment. Petrol. https://doi.org/10.1306/212F8175-2B24-11D78648000102C1865D

Doney, S.C., Ruckelshaus, M., Duffy, J.E., Barry, J.P., Chan, F., English, C.A., Galindo, H.M., Grebmeier, J.M., Hollowed, A.B., Knowlton, N., Polovina, J., Rabalais, N.N., Sydeman, W.J., Talley, L.D., 2012. Climate change impacts on marine ecosystems. Ann. Rev. Mar. Sci. 4, 11-37. https://doi.org/10.1146/annurev-marine-041911-111611

Flexas, J., Bota, J., Galmés, J., Medrano, H., Ribas-Carbó, M., 2006. Keeping a positive carbon balance under adverse conditions: Responses of photosynthesis and respiration to water stress. Physiol. Plant. https://doi.org/10.1111/j.13993054.2006.00621.x

Hanson, A.R., Shriver, W.G., 2006. Breeding birds of northeast salt marshes: Habitat use and conservation. Stud. in Avian Biol. Conserv. 141-154.

Hartig, E.K., Kolker, A.S., Gornit, V.C., 2000. Climate change impacts on saltmarsh morphology in Jamaica Bay, New York City. 11th Int. Peat Congr.

Hartman, J., Caswell, H., Valiela, I., 1983. Effects of wrack accumulation on salt marsh vegetation. Oceanol. Acta Actes 17e, 99-102.

Hopkinson, C.S., Schubauer, J.P., 1984. Static and Dynamic Aspects of Nitrogen Cycling in the Salt Marsh Graminoid Spartina Alterniflora. Ecology 65, 961-969. https://doi.org/10.2307/1938068

Howes, B.L., Goehringer, D.D., 1994. Porewater drainage and dissolved organic carbon and nutrient losses through the intertidal creekbanks of a New England salt marsh. Mar. Ecol. Prog. Ser. 114, 289-302. 
Hunter, R.D., 1976. Changes in carbon and nitrogen content during decomposition of three macrophytes in freshwater and marine environments. Hydrobiologia 51, 119-128. https://doi.org/10.1007/BF00009827

Johnson, D.S., Warren, R.S., Deegan, L.A., Mozdzer, T.J., 2016. Saltmarsh plant responses to eutrophication. Ecol. Appl. 26, 2647-2659. https://doi.org/10.1002/eap.1402

Kozlowski, T.T., 1999. Soil Compaction and Growth of Woody Plants. Scand. J. For. Res. https://doi.org/10.1080/02827589950154087

Leonard, L.A., Luther, M.E., 1995. Flow hydrodynamics in tidal marsh canopies. Limnol. Oceanogr. 40, 1474-1484. https://doi.org/10.4319/lo.1995.40.8.1474

Levine J. Stephen Brewer and Mark D. Bertness, J.M., Levine J. Stephen Brewer and Mark D. Bertness, J.M., 1998. Nutrients, competition and plant zonation in a New England salt marsh competitive reversal, Distichlis, Juncus, nutrients, Spartina, stress gradient. J. Ecol. 86, 285-292.

Linhoss, A.C., Kiker, G., Shirley, M., Frank, K., 2015. Sea-Level Rise, Inundation, and Marsh Migration: Simulating Impacts on Developed Lands and Environmental Systems. J. Coast. Res. 299, 36-46. https://doi.org/10.2112/JCOASTRES-D-13-00215.1

Luo, M.B., Liu, F., Xu, Z.L., 2012. Growth and nutrient uptake capacity of two cooccurring species, Ulva prolifera and Ulva linza. Aquat. Bot. 100, 18-24. https://doi.org/10.1016/j.aquabot.2012.03.006

Lyons, D.A., Arvanitidis, C., Blight, A.J., Chatzinikolaou, E., Guy-Haim, T., Kotta, J., Orav-Kotta, H., Queirós, A.M., Rilov, G., Somerfield, P.J., Crowe, T.P., 2014. Macroalgal blooms alter community structure and primary productivity in marine ecosystems. Glob. Chang. Biol. 20, 2712-2724.

https://doi.org/10.1111/gcb.12644

Macreadie, P.I., Hughes, A.R., Kimbro, D.L., 2013. Loss of "Blue Carbon" from Coastal Salt Marshes Following Habitat Disturbance. PLoS One 8. https://doi.org/10.1371/journal.pone.0069244

Martin, R.M., 2018. Sea-level rise and macroalgal blooms may combine to exacerbate decline in Spartina patens and Spartina alterniflora marshes Sea-level rise and macroalgal blooms may combine to exacerbate decline in Spartina patens and Spartina alterniflora marshes. Hydrobiologia. https://doi.org/10.1007/s10750018-3689-6

Martin, R.M., Moseman-Valtierra, S., 2017. Different short-term responses of greenhouse gas fluxes from salt marsh mesocosms to simulated global change 
drivers. Hydrobiologia 802, 71-83. https://doi.org/10.1007/s10750-017-3240-1

Martin, R.M., Moseman-Valtierra, S., 2015. Greenhouse Gas Fluxes Vary Between Phragmites Australis and Native Vegetation Zones in Coastal Wetlands Along a Salinity Gradient. Wetlands 35, 1021-1031. https://doi.org/10.1007/s13157-0150690-y

McFarlin, C.R., Brewer, J.S., Buck, T.L., Pennings, S.C., 2008. Impact of fertilization on a salt marsh food web in Georgia. Estuaries and Coasts 31, 313-325. https://doi.org/10.1007/s12237-008-9036-9

McLeod, E., Chmura, G.L., Bouillon, S., Salm, R., Björk, M., Duarte, C.M., Lovelock, C.E., Schlesinger, W.H., Silliman, B.R., 2011. A blueprint for blue carbon: Toward an improved understanding of the role of vegetated coastal habitats in sequestering CO2. Front. Ecol. Environ. 9, 552-560. https://doi.org/10.1890/110004

Moseman-Valtierra, S., 2013. Reconsidering climatic roles of marshes: Are they sinks or sources of greenhouse gases?, in: Marshes: Ecology, Management and Conservation.

Moseman-Valtierra, S., Abdul-Aziz, O.I., Tang, J., Ishtiaq, K.S., Morkeski, K., Mora, J., Quinn, R.K., Martin, R.M., Egan, K., Brannon, E.Q., Carey, J., Kroeger, K.D., 2016. Carbon dioxide fluxes reflect plant zonation and belowground biomass in a coastal Marsh. Ecosphere 7. https://doi.org/10.1002/ecs2.1560

Neubauer, S.C., 2010. Silliman, B. R., E. D. Grosholz, and M. D. Bertness (ed.) Human Impacts on Salt Marshes: A Global Perspective. Wetlands 30, 173-175. https://doi.org/10.1007/s13157-009-0013-2

Newton, C., Thornber, C., 2013. Ecological Impacts of Macroalgal Blooms on Salt Marsh Communities. Estuaries and Coasts 36, 365-376. https://doi.org/10.1007/s12237-012-9565-0

Newton, C., Thornber, C., 2012. Abundance and Species Composition Surveys of Macroalgal Blooms in Rhode Island Salt Marshes. Northeast. Nat. 19, 501-516. https://doi.org/10.1656/045.019.0311

Nielsen, S.L., Banta, G.T., Pedersen, M.F., 2007. Decomposition Of Marine Primary Producers: Consequences For Nutrient Recycling And Retention In Coastal Ecosystems, in: Estuarine Nutrient Cycling: The Influence of Primary Producers. pp. 187-216. https://doi.org/10.1007/978-1-4020-3021-5_7

Peckol, P., Rivers, J.S., 1995. Competive interactions between the opportunisitic macroalgae Cladophora vagabunda (Chlorophyta) and Gracilaria tikvahiae (Rhodophyta) under eutrophic conditions. J. Phycol. 31, 229-232. 
https://doi.org/10.1111/j.0022-3646.1995.00229.x

Pennings, S.C., Grant, M.B., Bertness, M.D., 2005. Plant zonation in low-latitude salt marshes: Disentangling the roles of flooding, salinity and competition. J. Ecol. 93, 159-167. https://doi.org/10.1111/j.1365-2745.2004.00959.x

Pennings, S.C., Stanton, L.E., Brewer, J.S., 2002. Nutrient effects on the composition of salt marsh plant communities along the southern Atlantic and Gulf Coasts of the United States. Estuaries 25, 1164-1173.

Poffenbarger, H.J., Needelman, B.A., Megonigal, J.P., 2011. Salinity influence on methane emissions from tidal marshes. Wetlands 31, 831-842. https://doi.org/10.1007/s13157-011-0197-0

Portnoy, J.W., Valiela, I., 1997. Short-term effects of salinity reduction and drainage on salt-marsh biogeochemical cycling and Spartina (Cordgrass) production. Estuaries. https://doi.org/10.2307/1352615

Ramesh Reddy, K., DeLaune, R., 2010. Biogeochemistry of Wetlands, Biogeochemistry of Wetlands. https://doi.org/10.1201/9780203491454

Raposa, K.B., Cole Ekberg, M.L., Burdick, D.M., Ernst, N.T., Adamowicz, S.C., 2017a. Elevation change and the vulnerability of Rhode Island (USA) salt marshes to sea-level rise. Reg. Environ. Chang. 17, 389-397. https://doi.org/10.1007/s10113-016-1020-5

Raposa, K.B., Roman, C.T., 2006. Seasonal habitat-use patterns of nekton in a tiderestricted and unrestricted New England salt marsh. Wetlands 21, 451-461. https://doi.org/10.1672/0277-5212(2001)021[0451:shupon]2.0.co;2

Raposa, K.B., Weber, R.L., Ferguson, W., Hollister, J., Rozsa, R., Maher, N., Gettman, A., 2019. Drainage enhancement effects on a waterlogged Rhode Island (USA) salt marsh. Estuar. Coast. Shelf Sci. https://doi.org/10.1016/j.ecss.2019.106435

Raposa, K.B., Weber, R.L.J., Ekberg, M.C., Ferguson, W., 2017b. Vegetation Dynamics in Rhode Island Salt Marshes During a Period of Accelerating Sea Level Rise and Extreme Sea Level Events. Estuaries and Coasts 40, 640-650. https://doi.org/10.1007/s12237-015-0018-4

Reddy, K.R., DeLaune, R.D., n.d. Biogeochemistry of Wetlands.

Roman, C.T., Jaworski, N., Short, F.T., Findlay, S., Warren, R.S., 2000. Estuaries of the northeastern United States: Habitat and land use signatures. Estuaries. https://doi.org/10.2307/1352997 
Ryan, M.G., 1991. Effects of Climate Change on Plant Respiration. Ecol. Appl. 1, 157-167. https://doi.org/10.2307/1941808

Sallenger, A.H., Doran, K.S., Howd, P.A., 2012. Hotspot of accelerated sea-level rise on the Atlantic coast of North America. Nat. Clim. Chang. 2, 884-888. https://doi.org/10.1038/nclimate1597

Scanlan, C.M., Foden, J., Wells, E., Best, M.A., 2007. The monitoring of opportunistic macroalgal blooms for the water framework directive. Mar. Pollut. Bull. 55, 162-171. https://doi.org/10.1016/j.marpolbul.2006.09.017

Sinha, E., Michalak, A.M., Balaji, V., 2017. Eutrophication will increase during the 21 st century as a result of precipitation changes. Science (80-. ). 357. https://doi.org/10.1126/science.aan2409

Slocum, M.G., Mendelssohn, I.A., Kuhn, N.L., 2005. Effects of sediment slurry enrichment on salt marsh rehabilitation: Plant and soil responses over seven years. Estuaries. https://doi.org/10.1007/BF02696063

Stein, B.A., Staudt, A., Cross, M.S., Dubois, N.S., Enquist, C., Griffis, R., Hansen, L.J., Hellmann, J.J., Lawler, J.J., Nelson, E.J., Pairis, A., 2013. Preparing for and managing change: Climate adaptation for biodiversity and ecosystems. Front. Ecol. Environ. https://doi.org/10.1890/120277

Ström, L., Ekberg, A., Mastepanov, M., Christensen, T.R., 2003. The Effect of Vascular Plants on Carbon Turnover and Methane Emissions from a Tundra Wetland methane emissions from a tundra wetland 1185-1192. https://doi.org/10.1046/j.1365-2486.2003.00655.x

Tonjes, D.J., 2013. Impacts from ditching salt marshes in the mid-Atlantic and northeastern United States. Environ. Rev. https://doi.org/10.1139/er-2013-0003

Tyrrell, M.C., Thornber, C.S., Burkhardt, J.A., Congretel, M., 2015. The Influence of Salt Marsh Fucoid Algae (Ecads) on Sediment Dynamics of Northwest Atlantic Marshes. Estuaries and Coasts 38, 1262-1273. https://doi.org/10.1007/s12237014-9919-х

Valiela, I., Fox, S.E., 2008. Managing coastal wetlands. Science (80-. ). https://doi.org/10.1126/science. 1153477

Valiela, I., McClelland, J., Hauxwell, J., Behr, P.J., Hersh, D., Foreman, K., 1997. Macroalgal blooms in shallow estuaries: Controls and ecophysiological and ecosystem consequences. Limnol. Oceanogr. 42, 1105-1118. https://doi.org/10.4319/lo.1997.42.5_part_2.1105

Valiela, I., Teal, J.M., 1974. Nutrient limitation in salt marsh vegetation. Ecol. 
Halophytes 547-563.

van Hulzen, J.. B., Van Soelen, J., Herman, P.M.. M.J., Bouma, T.J.J., 2006. The significance of spatial and temporal patterns of algal mat deposition in structuring salt marsh vegetation. J. Veg. Sci. 17, 291. https://doi.org/10.1658/11009233(2006)017[0291:TSOSAT]2.0.CO;2

Viaroli, P., Fumagalli, I., Cavalca, M., 1992. Chemical composition and decomposition of Ulva rigida in a coastal lagoon (Sacca di Goro, Po River Delta), in: Marine Coastal Eutrophication. pp. 471-474. https://doi.org/10.1016/B978-0444-89990-3.50044-4

Wang, B., Jin, H., Li, Q., Chen, D., Zhao, L., Tang, Y., Kato, T., Gu, S., 2017. Diurnal and Seasonal Variations in the Net Ecosystem CO2 Exchange of a Pasture in the Three-River Source Region of the Qinghai -Tibetan Plateau. PLoS One 12. https://doi.org/10.1371/journal.pone.0170963

Wang, M., He, D., Shen, F., Huang, J., Zhang, R., Liu, W., Zhu, M., Zhou, L., Wang, L., Zhou, Q., 2019. Effects of soil compaction on plant growth, nutrient absorption, and root respiration in soybean seedlings. Environ. Sci. Pollut. Res. https://doi.org/10.1007/s11356-019-05606-z

Wasson, K., Jeppesen, R., Endris, C., Perry, D.C., Woolfolk, A., Beheshti, K., Rodriguez, M., Eby, R., Watson, E.B., Rahman, F., Haskins, J., Hughes, B.B., 2017. Eutrophication decreases salt marsh resilience through proliferation of algal mats. Biol. Conserv. 212, 1-11. https://doi.org/10.1016/j.biocon.2017.05.019

Watson, E.B., Oczkowski, A.J., Wigand, C., Hanson, A.R., Davey, E.W., Crosby, S.C., Johnson, R.L., Andrews, H.M., 2014. Nutrient enrichment and precipitation changes do not enhance resiliency of salt marshes to sea level rise in the Northeastern U.S. Clim. Change 125, 501-509. https://doi.org/10.1007/s10584014-1189-x

Watson, E.B., Szura, K., Wigand, C., Raposa, K.B., Blount, K., Cencer, M., 2016. Sea level rise, drought and the decline of Spartina patens in New England marshes. Biol. Conserv. 196, 173-181. https://doi.org/10.1016/j.biocon.2016.02.011

Watson, E.B., Wigand, C., Davey, E.W., Andrews, H.M., Bishop, J., Raposa, K.B., 2017. Wetland Loss Patterns and Inundation-Productivity Relationships Prognosticate Widespread Salt Marsh Loss for Southern New England. Estuaries and Coasts. https://doi.org/10.1007/s12237-016-0069-1

Watson, E.B., Wigand, C., Oczkowski, A.J., Sundberg, K., Vendettuoli, D., Jayaraman, S., Saliba, K., Morris, J.T., 2015. Ulva additions alter soil biogeochemistry and negatively impact Spartina alterniflora growth. Mar. Ecol. 
Prog. Ser. 532, 59-72. https://doi.org/10.3354/meps11334

Weston, N.B., 2014a. Declining Sediments and Rising Seas: An Unfortunate Convergence for Tidal Wetlands. Estuaries and Coasts 37, 1-23.

https://doi.org/10.1007/s12237-013-9654-8

Weston, N.B., 2014b. Declining Sediments and Rising Seas: An Unfortunate Convergence for Tidal Wetlands. Estuaries and Coasts 37, 1-23. https://doi.org/10.1007/s12237-013-9654-8

Wigand, C., Ardito, T., Chaffee, C., Ferguson, W., Paton, S., Raposa, K., Vandemoer, C., Watson, E., 2017. A Climate Change Adaptation Strategy for Management of Coastal Marsh Systems. Estuaries and Coasts 40, 682-693. https://doi.org/10.1007/s12237-015-0003-y

Wilson, B.J., Mortazavi, B., Kiene, R.P., 2015. Spatial and temporal variability in carbon dioxide and methane exchange at three coastal marshes along a salinity gradient in a northern Gulf of Mexico estuary. Biogeochemistry 123, 329-347. https://doi.org/10.1007/s10533-015-0085-4

Yates, J.L., Peckol, P., 1993. Effects of nutrient availability and herbivory on polyphenolics in the seaweed Fucus vesiculosus. Ecology 74, 1757-1766. https://doi.org/10.2307/1939934

Zajac, R., Kelly, E., Perry, D., Espinosa, I., 2017. Population ecology of the snail Melampus bidentatus in changing salt marsh landscapes. Mar. Ecol. 38, 1-17. https://doi.org/10.1111/maec.12420 


\title{
CHAPTER 2
}

\section{MONITORING SALT MARSH VEGETATION AND SOIL RESPONSE TO RUNNEL AND SEDIMENT ENHANCEMENT INTERVENTIONS}

\author{
Danielle C. Perry ${ }^{1}$ Wenley Ferguson ${ }^{2}$ and Carol S. Thornber ${ }^{1}$ \\ ${ }^{1}$ Natural Resources Science, University of Rhode Island, Kingston, RI USA 02881 \\ ${ }^{2}$ Save The Bay, Providence, RI USA 02881
}

Manuscript in preparation for submission to Biological Conservation 


\section{$\underline{\text { Abstract }}$}

Sea level rise within New England is accelerating at a rate faster than the global average, leaving salt marshes susceptible to degradation. Sediment enhancement and hydrological alterations (e.g. runnel installations) projects are two types of climate change adaptation techniques that have been implemented in New England to combat the effects of sea level rise within salt marshes. Sediment enhancement is used to increase the elevation and runnels (shallow ditches) to enhance drainage in drowning marshes. In this study, we investigated the impacts of these climate change adaptation methods on soil properties, vegetation composition, and greenhouse gas fluxes (methane and carbon dioxide). Spartina alterniflora stem density in certain runnel areas increased after runnels were installed and Spartina patens (high marsh plant) were able to persist under this treatment. The sediment enhancement treatment resulted in low belowground biomass, soil \% organic matter, and plant recolonization, suggesting that the added sediment material inhibited vegetation growth. There was a significant difference in carbon dioxide uptake rates among treatments, with the unmanipulated (Control) areas having the highest uptake rates. 


\section{$\underline{\text { Introduction }}$}

One of the major threats to coastal environments is accelerated relative sea level rise (hereafter referred to as SLR), which is a prevalent impact of climate change. Coastal environments within the Northeastern USA, in particular, are greatly impacted by SLR effects, with New England itself facing SLR rates three to four times the global average (Ashton et al., 2008; Sallenger et al., 2012; Weston, 2014; Carey et al., 2017). SLR can result in increased flooding, decreased resiliency to storms, damage to infrastructure in low-lying and coastal areas, and loss of coastal wetlands (Ashton et al., 2008; Wigand et al., 2017). Wetlands with efficient accretion and sedimentation rates as well as high wetland migration potential can combat SLR impacts (Delaune et al., 1983; Boyd and Sommerfield, 2016; Borchert et al., 2018). However, areas with low sedimentation rates, and highly populated coastal areas, may not be able to migrate or accrete at a rate that can withstand SLR, resulting in loss of key wetland ecosystem functions (Weston, 2014a).

Due to high productivity and slow decomposition rates, salt marshes serve as important carbon sinks (Reddy and DeLaune, 2010). They are also a vital food source, breeding habitat, and nursery ground for birds (including the vulnerable salt marsh sparrow, Ammodramus caudacutus) and aquaculture species including fish and shellfish (Hanson and Shriver, 2006; Raposa and Roman, 2006; Bayard and Elphick, 2011). These environments also provide flood abatement and help prevent coastal erosion (Leonard and Luther, 1995; Barbier et al., 2011). These functions are essential for regions that rely on aquaculture to support the economy and densely populated 
coastal areas that benefit from flood abatement and erosion control to prevent damage to infrastructure.

Due to reduced sediment supply caused by coastal development, reforestation, and dam construction, marshes within the Northeast USA, including those in Narragansett Bay, have lower accretion rates than current and projected SLR rates (Sallenger et al., 2012; Weston, 2014; Watson et al., 2017). Organic matter supply, a major contributor to New England marsh growth, has also been reduced due to the negative impacts of coastal eutrophication on marsh belowground biomass and organic matter production (Allen, 1990). Coastal development within Narragansett Bay has also lowered the potential for marsh migration, which is another natural mechanism and response to SLR effects (Roman et al., 2000). Narragansett Bay’s low elevation marshes add an addition challenge to combat SLR effects. As a result of these factors, Narragansett Bay marshes are ponding and not fully draining even during low tides, leading to waterlogged soils, dieback and bare areas, and vegetation loss (Hartig et al., 2000; Alber et al., 2008; Carey et al., 2017; Raposa et al., 2017a). Rhode Island marshes have also experienced changes in vegetation composition, where low marsh plant species, such as Spartina alterniflora, are replacing high marsh plant species, such as Spartina patens (Raposa et al., 2017b).

Although climate change mitigation research (e.g. efforts to reduce greenhouse gas emissions) serves an important purpose, climate change adaption research is equally needed, as it can focus on preparing for, coping with, and responding to the impacts of current and future system changes (Stein et al., 2013; Wigand et al., 2017). One climate adaptation approach to build salt marsh resiliency is sediment 
enhancement (SE), also known as thin layer deposition, where dredged sediment material is added to the salt marsh surface (Cahoon et al., 2019). The purpose of this technique is to raise the salt marsh platform to an elevation that can withstand future projections of SLR.

Another technique to offset SLR impacts is a type of hydrological climate change adaptation, where shallow dredged ditches (runnels) are dug into the existing marsh platform to drain excess water from high marsh areas that have ponded. Since the 1930s, human-made ditches have become a prominent feature of Atlantic Coast salt marshes (Corman et al., 2012). Historically, deep ditches have been used for mosquito control and agriculture purposes (Dale et al., 1993; Breitfuss and Connolly, 2004; Dale and Knight, 2006; Dale, 2008). However, our study describes an alternate use of ditches as shallow runnels that helps to preserve marsh ecological functions in light of climate change. Runnels constructed in this study are shallow $(0.15-0.5 \mathrm{~m}$ wide by $0.2-0.5 \mathrm{~m} \mathrm{depth}$ ) and strategically placed by unnatural pools, which helps to mitigate some of the negative effects (marsh subsidence, decrease in natural pools) of historical ditches of greater depths (Dale et al., 1993). These unnatural pools are a result of excess tidal inundation that leads to vegetation die off and displacement of high marsh plants (Raposa et al., 2017b).

The U.S. Fish and Wildlife Service and Rhode Island's Save the Bay implemented SE and hydrological (shallow runnel) projects at salt marsh sites in Narragansett, RI. The purpose of this study was to assess salt marsh habitat response, including vegetation, soil, and greenhouse gas fluxes, of the treated vs. control (untreated) areas. We expected that runnels would promote plant recovery, including 
increases in belowground biomass, and allow for the persistence of high marsh plant species. By contrast, the SE project would demonstrate more gradual signs of plant recovery. The impacts of these projects will have implications on future coastal resiliency initiatives within New England and offer potential methods to mitigate SLR impacts globally.

\section{Methodology}

Our field sites were located along fringing salt marshes in the Narrow River in Narragansett, Rhode Island USA, where dredged runnels (2015) and 10cm thick, fine sand SE (2016) projects were conducted by the U.S. Fish and Wildlife Service and Save the Bay. The runnels were created using hand shovels and an excavator. The sediment for the SE project was distributed using a hydraulic dredge pipeline and excavator. Save the Bay (STB) performed the initial preliminary site assessments in 2014, including vegetation surveys, before the runnels were implemented. As these methods were different from those used in this study to track recovery over time, we used STB results as a reference but do not include them in statistical analyses. In May 2017, an initial planting effort of Spartina alterniflora and Distichlis spicata occurred to jumpstart vegetation recolonization for the SE area, but most plants did not survive by the end of the 2017 growing season (October).

For our post-manipulation study, we had four treatments: control (unaltered), sediment enhancement, soft sediment runnels, and vegetated runnels. We separated runnels into two different treatments based on their field characteristics and elevation at the start of this study in 2017; soft sediment runnels were surrounded by unconsolidated sediment, bare, and at a lower elevation, while vegetated runnels were 
surrounded by vegetation, more stable sediment, and at a higher elevation. The Control and the Soft Sediment Runnel were at similar elevations, and the Sediment Enhancement was at a significantly higher elevation than the other 3 treatments $\left(F_{3,35}=22.9, p<0.01\right)$. Average elevations for treatments were as follows: 1$)$ Control: $30.9 \mathrm{~cm} \pm 5.1(1.0 \mathrm{ft}$ NAVD88); 2) Soft Sediment Runnel: $24.2 \mathrm{~cm} \pm 0.8(0.8 \mathrm{ft}$ NAVD88); 3) Vegetated Runnel: $39.6 \pm 10.1$ (1.3ft NAVD88); and 4) Sediment Enhancement: $51.4 \mathrm{~cm} \pm 6.4(1.7 \mathrm{ft}$ NAVD88).

We collected post-manipulation data using two salt marsh sites for each treatment, with one linear transect $(12 \mathrm{~m})$ per site, except for the SE transects, which were both located at the same site ( $68 \mathrm{~m}$ apart), due to the limiting areas of sediment placement. Along each transect, we established six circular plots $(26 \mathrm{~cm}$ in diameter), spaced $2 \mathrm{~m}$ apart. Plot measurements were taken in August and October of 2018 and 2019; these times represented the beginning, middle, and end of each salt marsh growing season in New England. We were not able to sample during June or July due to closure of our field sites for salt marsh sparrow nesting. Soil depth $(5 \mathrm{~cm}) \mathrm{pH}$ was measured at each plot using an Electronic Soil Tester pH Analyzer (FLIR Commercial Systems Inc., Nashua, New Hampshire). Within each plot, the S. alterniflora stems were counted and the percent covers of the remaining plant species were measured. Core samples ( $5 \mathrm{~cm}$ height, $5 \mathrm{~cm}$ diameter) were collected $0.5 \mathrm{~m}$ outside of the plot to avoid disturbing the plot, and later processed to measure belowground biomass, percent organic matter, percent moisture, and bulk density. The core samples were weighed for wet weight, dried at $30^{\circ} \mathrm{C}$ for 3 days, weighed for dry weight, and then sieved ( $2 \mathrm{~mm}$ sieve). The sieve separated the root belowground biomass and sediment. 
The belowground biomass was then weighed and the sediment (10-15g) was burned at $400{ }^{\circ} \mathrm{C}$ for 16 hours. The percent organic matter of the sample was determined using the Loss on Ignition Method (Ball 1964). Percent moisture was calculated using the wet weight and dry weight of each soil sample.

Greenhouse gas (GHG) fluxes (carbon dioxide and methane) of each plot were measured in monthly from August to October of 2017-2019. Carbon dioxide $\left(\mathrm{CO}_{2}\right)$ and methane $\left(\mathrm{CH}_{4}\right)$ fluxes of each plot were measured using a cavity-ring down spectrometer (CRDS) (Model G2508, Picarro Inc., Santa Clara, California, USA). CRDS analyzer sampling methods were based on methodology described in Martin and Moseman-Valtierra (2015). Before the GHG flux measurements took place, a polyether foam ring was secured over the plot and vegetation (without disturbing the plants). Each time prior to measuring, a transparent polycarbonate chamber $(41 \mathrm{~cm}$ tall $\mathrm{x} 27 \mathrm{~cm}$ diameter) was placed over the foam ring to create a gas tight seal (as described in Martin and Moseman-Valtierra 2015). The chamber was connected to the CRDS via a vacuum pump and tubing $(0.8 \mathrm{~mm}$ in diameter). Two battery powered fans were installed within the chamber to homogenize the air. Chamber deployments were maintained for each mesocosm for 4 minutes. A temperature logger (Hobo, Bourne, MA) was mounted within the chamber, recording the temperature every 10 seconds during this period.

Gas fluxes were calculated from linear rates of change in gas emission concentrations (ppm) over time using the Ideal Gas Law (as described in Martin and Moseman-Valtierra 2015). Positive fluxes were defined as those in which gas concentrations increased over time within the chamber, representing emission from the 
plot surface to the atmosphere. Negative fluxes are defined as those in which gas concentrations decreased over time, representing net uptake from the atmosphere by the salt marsh plot (Moseman-Valtierra et al. 2016).

We used two-way and repeated measures ANOVAs to test for differences in treatments over time for the following variables: S. alterniflora stem count, species percent cover, belowground biomass, organic matter, salinity, percent moisture, $\mathrm{pH}$, and gas fluxes.

$\underline{\text { Results }}$

Pre/Post treatment community composition

Open water within the runnel treatment decreased from $27 \%$ (prior) to $0 \%$ after the runnels were implemented (data collected by Save the Bay). The unvegetated areas (combined bare and open water areas) in the Soft Sediment Runnel were 11\% less in August 2019 than August 2014 before the runnels were implemented (Figure 1). In the Control, unvegetated areas were 51\% greater in August 2019 than in August 2014. The S. alterniflora percent cover of the Soft Sediment Runnel was approximately $32 \%$ and 42\% higher in August 2018 and 2019, respectively, than the Runnel area in 2014 (Figure 2). The S. patens percent cover in the Vegetated Runnel was $49 \%$ and $54 \%$ higher in August 2018 and 2019, respectively, than the Runnel area in 2014 (Figure 3). The S. patens of the Control was 84\% and 87\% lower in August 2018 and 2019, respectively, then the Control area in 2014 (Figure 3). The S. alterniflora of the Control was 15\% and 14\% higher in August 2018 and 2019, respectively, then the Control area in 2014 (Figure 2).

Post treatment vegetation 
From August 2018 to August 2019, the bare areas in the Soft Sediment Runnel and Vegetated Runnel decreased by $38 \%$ and $12 \%$, respectively, while the bare areas in the Control and Sediment Enhancement stayed relatively consistent (Figure 1). The bare areas in October 2017 compared to October 2019 decreased $78 \%$ and $28 \%$ in the Soft Sediment Runnel and Control, respectively, while the Vegetated Runnel and Sediment Enhancement stayed relatively consistent (treatment: $F_{3,117}=78.99, p$ $<0.0001$; time $\mathrm{F}_{, 117}=15.06, \mathrm{p}<0.0001$; treatment $*$ time: $\left.\mathrm{F}_{12,117}=2.73, \mathrm{p}=0.0027\right)$.

There was a mean increase in S. alterniflora stem density in the Soft Sediment Runnel and Control, 4x and 1.9x in October 2018 and 2.2x and 1.3x in October 2019, respectively, compared to October 2017 (Figure 4). By contrast, there was a steady decrease in S. alterniflora stem density over time in the Vegetated Runnel and minimal to no growth in the Sediment Enhancement (overall model $F_{71,224}=12.72$, $\mathrm{p}<0.0001 ;$ treatment: $\mathrm{F}_{3,224}=75.88, \mathrm{p}<0.0001 ;$ time: $\mathrm{F}_{6,224}=19.32, \mathrm{p}<0.0001$; treatment*time: $\left.\mathrm{F}_{18,224}=7.58, \mathrm{p}<0.0001\right)$. There was no significant difference in $S$. alterniflora stem height among treatments, but there was an interaction effect (treatment: $\mathrm{F}_{2,783}=0.69, \mathrm{p}=0.51 ;$ time $\mathrm{F}_{4,783}=89.63, \mathrm{p}<0.0001$; treatment $*$ time: $\left.\mathrm{F}_{16,783}=7.70, \mathrm{p}<0.0001\right)$. The Sediment Enhancement was not included in this analysis for stem height, since there were not enough $S$. alterniflora stems present (average $\mathrm{n}=0.12$ per plot).

S. alterniflora percent cover was close to zero in October 2019 than $40 \%$ cover ( 237x higher) in October 2017 in the Soft Sediment Runnel (Figure 2). The Control was $~ 14 x$ greater in October 2019 than October 2017, while the Vegetated Runnel was 7x greater in October 2019 than October 2017. There was minimal to no $S$. 
alterniflora percent cover in the Sediment Enhancement from 2017-2019 (overall model $F_{59,118}=10.16, p<0.0001$; treatment: $F_{2,118}=78.92, p<0.0001 ;$ time: $F_{3,118}=$ 7.41, $\mathrm{p}=0.0001 ;$ treatment $*$ time: $\left.\mathrm{F}_{11,118}=3.45, \mathrm{p}=0.0004\right)$.

S. patens was not present in the Soft Sediment Runnel and Sediment Enhancement areas from 2017-2019, while it declined in the Control from $8 \%$ to $0 \%$ from 2017-2019 (Figure 3). By contrast, the percent cover of S. patens was significantly higher in the Vegetation Runnel treatment ( 11.6x higher than the Control) compared to the other treatments (overall model $\mathrm{F}_{69,194}=9.19, \mathrm{p}<0.0001$; treatment: $\mathrm{F}_{1,194}=113.12, \mathrm{p}<0.0001$; time: $\mathrm{F}_{5,194}=3.58, \mathrm{p}=0.0040$; treatment $*$ time: $\left.\mathrm{F}_{16,194}=4.87, \mathrm{p}<0.0001\right)$.

\section{Belowground Biomass (BGB) and Organic Matter}

Belowground biomass was 2.6x and 1.9x higher in the Control than the Soft Sediment Runnel and Vegetated Runnel areas, respectively. Sediment Enhancement had very low belowground biomass (mean $=0.04 \mathrm{~g}$; Figure 5), with a significant interaction (overall model $\mathrm{F}_{53,111}=8.83, \mathrm{p}<0.0001$; treatment: $\mathrm{F}_{3,111}=145.41$, $\mathrm{p}<0.0001$; time: $\mathrm{F}_{3,111}=7.71, \mathrm{p}=0.0001$; treatment*time: $\mathrm{F}_{9,111}=2.21, \mathrm{p}=0.026$ ).

Sediment Enhancement had $\sim 99 \%$ less organic matter than the other treatments (overall model $\mathrm{F}_{53,106}=36.03, \mathrm{p}<0.0001$; treatment: $\mathrm{F}_{3,106}=453.85, \mathrm{p}<0.0001$; time: $\mathrm{F}_{3,106}=2.85, \mathrm{p}=0.041$; treatment $*$ time: $\mathrm{F}_{9,106}=0.92, \mathrm{p}=0.51 ;$ Figure 6).

\section{Abiotic Soil Factors: Salinity, percent moisture, and $\mathrm{pH}$}

Sediment Enhancement had significantly higher salinity than the other three treatments. Sediment Enhancement salinity was $70 \%$ higher than the Control. The Control was $29 \%$ and $25 \%$ higher salinity than Soft Sediment Runnel and Vegetated 
Runnel areas, respectively (overall model $\mathrm{F}_{31,284}=19.80, \mathrm{p}<0.0001$; treatment: $\mathrm{F}_{3,284}=$ 165.53, $\mathrm{p}<0.0001 ;$ time: $\mathrm{F}_{7,284}=8.03, \mathrm{p}<0.0001$; treatment $*$ time: $\mathrm{F}_{21,284}=1.36, \mathrm{p}=$ 0.13; Table 2).

Sediment Enhancement had at least $75 \%$ lower moisture than the other three treatments at each time point (Table 3; overall model $\mathrm{F}_{53,111}=750.33, \mathrm{p}<0.0001$; treatment: $F_{3,111}=4087.68, p<0.0001$; time: $F_{3,111}=1.47, p=0.23$; treatment $*$ time: $\left.\mathrm{F}_{9,111}=0.72, \mathrm{p}=0.69\right)$. By contrast, the Soft Sediment Runnel had significantly higher moisture than all other treatments.

The soil pH was significantly higher in the Sediment Enhancement compared to the other three treatments (overall model $F_{23,219}=29.89, p<0.0001$; treatment: $F_{3,219}$ $=140.66, \mathrm{p}<0.0001$; time: $\mathrm{F}_{5,219}=20.71, \mathrm{p}<0.0001$; treatment $*$ time: $\mathrm{F}_{15,219}=9.34, \mathrm{p}$ $<0.0001$; Table 4).

Greenhouse gas fluxes

There was not a significant difference in methane flux among treatments (overall model: $\mathrm{F}_{84,209}=0.44, \mathrm{p}=1.0$ ). There was significantly higher uptake in carbon dioxide in the Control than the other three treatments (12.6x Sediment Enhancement, 2.1x Soft Sediment Runnel, and 1.9x Vegetated Runnel; Figure 7; overall model $\mathrm{F}_{75,156}=9.60, \mathrm{p}<0.0001 ;$ treatment: $\mathrm{F}_{1,156}=13.75, \mathrm{p}=0.0003 ;$ time: $\mathrm{F}_{3,156}=35.73$, $\mathrm{p}<0.0001$; treatment*time: $\left.\mathrm{F}_{19,156}=9.62, \mathrm{p}<0.0001\right)$. Both runnel treatments took up significantly more carbon dioxide than Sediment Enhancement. The Soft Sediment Runnel showed more $\mathrm{CO}_{2}$ uptake in 2018 and 2019 than in 2017 (Figure 7). 


\section{$\underline{\text { Discussion }}$}

A prevalent issue within Rhode Island salt marshes is that low marsh species are displacing high marsh plants due to sea level rise impacts (Raposa et al., 2017b). This pattern is seen in the Control as S. patens in the Control gradually decreased from 2017-2019, as well as a decrease from initial conditions in S. patens coverage in 2014. By contrast, the Vegetated Runnel shows a decline in S. alterniflora in the Vegetated Runnel and the persistence of S. patens from 2017-2019, which suggests runnel effects in combination with higher elevations can help S. patens outcompete S. alterniflora. The results of this study suggest that runnel impacts have the potential to prevent the displacement of high marsh plants by low marsh plant species, but further monitoring is necessary to see if this pattern persists. In the past, hydrological manipulations (berm creation, culverts, and dikes) within salt marshes have been used to promote $S$. patens growth, mostly for agricultural purposes (Britton 1912; Smith and Bridges 1982; Sebold 1998). However, some of these methods have limited sedimentation, promoted the spread of the invasive species, Phragmites australis, within New England marshes, and altered biogeochemical processes within salt marshes (Crain et al. 2009; Tonjes, 2013). In this study, the runnel hydrological manipulation demonstrated an ability to combat SLR impacts and preserve high marsh habitat. This has positive implications on the vulnerable bird species, Ammodramus caudacutus or salt marsh sparrow, that nests within S. patens habitat (Bayard and Elphick, 2011). Without intervention, the impacts of SLR and excess tidal inundation may result in the continued decline in high marsh habitat, which will be detrimental to the salt marsh 
sparrow and other bird and invertebrate species that rely on high marsh habitat for survival (Bayard and Elphick, 2011; Zajac et al., 2017).

In a drainage enhancement study, Raposa et al. (2019) used linear creeks that were wider $(\sim 1.3-3.3 \mathrm{~m}$ in width and $\sim 0.5 \mathrm{~m}$ in depth) than the runnels used in our experiment and found no significant changes in pre-existing vegetation in control or the linear creek areas. However, in our study the high marsh plants decreased from 2017-2019 in the Control while Soft Sediment Runnel did not contain S. patens throughout that time period, but showed significant increase in S. alterniflora over time. This suggests that drainage treatments (linear creeks vs shallow runnels) can lead to varying results. There were some parallels between studies, as Raposa et al. (2019) found that linear creeks had the greatest impact on bare areas that were later revegetated. Although shallower runnels were used in this study, we found similar results, as the bare areas within the Soft Sediment Runnel decreased at a faster rate than the Control areas. The Control and the Soft Sediment Runnel increased in $S$. alterniflora percent cover from October 2017 to October 2018, but the rate of increase was $\sim 15 \mathrm{x}$ greater in the Soft Sediment Runnel than the Control suggesting a drainage impact.

This study showed an increase of belowground biomass in the Soft Sediment Runnel and decline in the Control from August 2018 to August 2019, but these are short term effects that needs longer term monitoring to determine if this pattern continues and will have lasting implications on the salt marsh sediment stability. However, the Control represented higher overall belowground biomass than the other treatments. Although the Control and Soft Sediment Runnel of this study were located 
at similar elevations, the Control represented better initial conditions (vegetated, stable sediment) than the Soft Sediment Runnel (bare and unconsolidated sediment) at the beginning of the study. The Soft Sediment Runnel areas were located by pools before the runnels were placed and the Control was not located by pooled areas, which could have resulted in these varying initial conditions. For future studies, an untreated control area by undrained pools would more accurately compare and depict the impacts of runnels. There was less of an increase in the Vegetated Runnel belowground biomass, which may be due to the decrease in S. alterniflora stems and prominence of $S$. patens, as $S$. patens has finer roots than S. alterniflora (MosemanValtierra et al., 2016). This could also explain the significantly lower belowground biomass and organic matter in the Vegetated Runnel compared to the Control, due to the difference in dominant vegetation.

One of the goals of climate change adaptation is to preserve coastal wetlands ecosystem functions for environmental purposes (Hartig et al., 2000; Barbier et al., 2011; Weston, 2014b; Linhoss et al., 2015; Crosby et al., 2016; Watson et al., 2017; Wigand et al., 2017). Greenhouse gas fluxes can assess the capability of these adaptation strategies to maintain an important salt marsh ecosystem function of carbon sequestration (McLeod et al., 2011; Moseman-Valtierra, 2013; Martin and MosemanValtierra, 2015). The Soft Sediment Runnel had higher carbon dioxide uptake in 2018 and 2019 than in 2017, which suggests an improvement in this ecological function in coordination with vegetation recovery. The Control showed the highest rates of $\mathrm{CO}_{2}$ uptake in 2018 likely due to the higher S. alterniflora stem count than the other treatments. The Control did not represent conditions of ponded areas, which likely led 
to better response of vegetation and $\mathrm{CO}_{2}$ uptake when compared to the Soft Sediment Runnel areas that were ponded before the runnels were implemented creating initial conditions that were more severely degraded.

Due to the higher elevation of the Vegetated Runnel compared to the Control and Soft Sediment Runnel we expected to see the differences in vegetation and $\mathrm{CO}_{2}$ uptake. Moseman-Valtierra et al. (2016) showed that S. alterniflora dominated areas removed $\mathrm{CO}_{2}$ from the atmosphere at a faster rate than $S$. patens dominated areas. Due to this, it was not unexpected that the $\mathrm{CO}_{2}$ fluxes are lower in 2019 than 2017 in the Vegetated Runnel, as there were less S. alterniflora stems in 2019. Carbon dioxide uptake was lower in all treatments in 2019 than 2018, which suggests that abiotic factors rather than treatment are having the greatest impact on $\mathrm{CO}_{2}$ fluxes during that period of measurements (Portnoy and Valiela, 1997; Poffenbarger et al., 2011; Wilson et al., 2015; Martin and Moseman-Valtierra, 2017; Wang et al., 2017).

The Narrow River SE project did not progress as expected, as the plots within this experiment had no natural revegetation growth throughout the study. This project deposited $\sim 10 \mathrm{~cm}$ of sediment, which is less than another SE project at Ninigret Pond in Charlestown, RI $(\sim 40 \mathrm{~cm})$ that occurred at the same time. The Ninigret Pond project experienced close to full revegetation by the third growing season, despite having much greater sediment deposition depth than the Narrow River project (W. Ferguson, personal communication). In other studies, Mendelssohn and Kuhn (2003) deposited $\sim 60 \mathrm{~cm}$ of sediment and reported full vegetation after two years. Slocum et al. (2005) found that moderate levels of sediment deposition $(5-12 \mathrm{~cm})$ produced the most beneficial and long-lasting effects on vegetation and soil. Therefore, it is likely that the 
amount of sediment deposited at the Narrow River site is not the main cause of hindered vegetation growth.

The sediment size used for this SE project was classified as fine sand (Hardy unpublished data), which could have been too fine for vegetation growth and promote soil drainage. Larger grain sized sediment, coarse sand, has been used in other SE projects within Rhode Island, which resulted in greater vegetation recolonization (C. Chaffee, personal communication). Croft et al. (2006) used medium sized sand in their sediment placement project and found vegetation to return after two growing seasons. Hardisky and Adams (1978) found that fine sediment placement material resulted in less stem growth than the use of larger grain sediment. Therefore, grain size may be an important influencer of vegetation recovery.

Due to the bare SE areas, evaporation was likely a large factor within this environment, which explains the high salinity and low moisture of this treatment, which caused an additional barrier to plant revegetation (Bertness et al., 1992; Bertness, 1992). Halophytes, such as Salicornia, were also seldom seen within these plots although having a high salinity tolerance. The SE areas often resulted in insignificant $\mathrm{CO}_{2}$ fluxes, which was expected given the lack of vegetation. Minimal microbial activity, which is suggested by the low organic matter and belowground biomass within the treatment, could also explain the lack of soil respiration (measured via $\mathrm{CO}_{2}$ emission) and insignificant flux (Reddy and DeLaune, 2010).

The SE area also did not have well established drainage. The high evaporation rates removed moisture from the sediment, but salt remained in the system leading to hypersaline areas. Although not represented in the study plots, SE areas closest to 
natural creeks and runnels had lower salinity, $\sim 30 \mathrm{ppt}$, and more positive vegetation regrowth (personal observation). The runnel treatments within this experiment had significantly lower salinity than the Control, matching results from other runnel studies (Dale, 2008; Dale and Knight, 2006). Incorporating runnels into SE projects has been practiced at the Ninigret SE project, which produced positive vegetation results that were partially attributed to the runnel impact (W. Ferguson personal communication). This suggests that establishing runnels within SE sites could serve as an important component to prevent hypersaline areas that hinder vegetation growth. Acknowledgements

Funding: National Science Foundation Graduate Research Fellowship (grant number DGE-1747454); University of Rhode Island (URI)'s Enhancement of Graduate Research Award; and the Association for the Sciences of Limnology and Oceanography Presentation and Travel Award (awarded to Danielle Perry).

We would like to thank C. Wigand and S. Moseman-Valtierra for support and aid in experimental design, J. Loffredo, J. Bishop, M. Smith, B. Michener, M. Zavell, and M. Sharkey, for field and laboratory assistance, and C. Wigand, R. Martin, A. Humphries, and M. Stolt for manuscript advice. Special thank you to US Fish and Wildlife Service (USFWS) for granting permits to complete this research. Hydrological restoration and sediment and enhancement were conducted by USFWS and Save The Bay. 
Table 1. Average percent cover of open water, Spartina alterniflora (dominant low marsh species) and Spartina patens (dominant high marsh species) before the runnels were placed in 2014.

\begin{tabular}{|c|c|c|}
\hline Treatment & Habitat Composition & $\begin{array}{l}\text { Average Percent } \\
\text { Cover } \pm \text { 1_standard } \\
\text { error }\end{array}$ \\
\hline Control & Open water & $13.56 \pm 0.14$ \\
\hline Control & Spartina alterniflora & $53.3 \pm 2.91$ \\
\hline Control & Spartina patens & $26.0 \pm 1.95$ \\
\hline Control & Other Vegetation & $12.89 \pm 5.99$ \\
\hline Control & Bare & $2.0 \pm 1$ \\
\hline Runnel & Open water & $27.0 \pm 9.11$ \\
\hline Runnel & Spartina alterniflora & $39.6 \pm 0.71$ \\
\hline Runnel & Spartina patens & $21.0 \pm 0.61$ \\
\hline Runnel & Bare & $8.6 \pm 0.58$ \\
\hline Runnel & Other Vegetation & $12.08 \pm 1.81$ \\
\hline
\end{tabular}


Table 2. Average salinity (psu) per treatment \pm 1 standard error.

\begin{tabular}{|c|c|c|}
\hline Treatment & Salinity (psu) & Month and Year \\
\hline Control & $35.5 \pm 2.8$ & August 2018 \\
\hline Sediment Enhancement & $51.5 \pm 3.3$ & August 2018 \\
\hline Soft Sediment Runnel & $22.8 \pm 4.0$ & August 2018 \\
\hline Vegetated Runnel & $26.6 \pm 3.3$ & August 2018 \\
\hline Control & $29.1 \pm 3.9$ & October 2018 \\
\hline Sediment Enhancement & $54.5 \pm 4.3$ & October 2018 \\
\hline Soft Sediment Runnel & $21.5 \pm 5.5$ & October 2018 \\
\hline Vegetated Runnel & $23.6 \pm 3.9$ & October 2018 \\
\hline Control & $31.9 \pm 0.9$ & August 2019 \\
\hline Sediment Enhancement & $64.2 \pm 1.6$ & August 2019 \\
\hline Soft Sediment Runnel & $27.3 \pm 1.3$ & August 2019 \\
\hline Vegetated Runnel & $25.7 \pm 0.9$ & August 2019 \\
\hline Control & $24.8 \pm 2.2$ & October 2019 \\
\hline Sediment Enhancement & $48.2 \pm 2.2$ & October 2019 \\
\hline Soft Sediment Runnel & $22.4 \pm 3.1$ & October 2019 \\
\hline Vegetated Runnel & $21.7 \pm 2.2$ & October 2019 \\
\hline
\end{tabular}


Table 3. Average percent moisture per treatment \pm 1 standard error.

\begin{tabular}{|c|c|c|}
\hline Treatment & Moisture (\%) & Month and Year \\
\hline Control & $85.0 \pm 0.7$ & August 2018 \\
\hline Sediment Enhancement & $19.1 \pm 0.7$ & August 2018 \\
\hline Soft Sediment Runnel & $87.8 \pm 1.0$ & August 2018 \\
\hline Vegetated Runnel & $84.2 \pm 0.8$ & August 2018 \\
\hline Control & $85.3 \pm 0.6$ & October 2018 \\
\hline Sediment Enhancement & $20.1 \pm 0.6$ & October 2018 \\
\hline Soft Sediment Runnel & $88.4 \pm 0.9$ & October 2018 \\
\hline Vegetated Runnel & $84.4 \pm 0.6$ & October 2018 \\
\hline Control & $85.8 \pm 0.9$ & August 2019 \\
\hline Sediment Enhancement & $20.4 \pm 0.9$ & August 2019 \\
\hline Soft Sediment Runnel & $88.1 \pm 1.2$ & August 2019 \\
\hline Vegetated Runnel & $84.6 \pm 0.9$ & August 2019 \\
\hline Control & $86.3 \pm 0.5$ & October 2019 \\
\hline Sediment Enhancement & $20.7 \pm 0.5$ & October 2019 \\
\hline Soft Sediment Runnel & $86.6 \pm 0.7$ & October 2019 \\
\hline Vegetated Runnel & $84.8 \pm 0.5$ & October 2019 \\
\hline
\end{tabular}


Table 4. Average $\mathrm{pH}(5 \mathrm{~cm}$ depth $)$ per treatment \pm 1 standard error.

\begin{tabular}{|c|c|c|}
\hline Treatment & $\mathrm{pH}$ & Month and Year \\
\hline Control & $5.2 \pm 0.1$ & August 2018 \\
\hline Sediment Enhancement & $7.6 \pm 0.1$ & August 2018 \\
\hline Soft Sediment Runnel & $6.4 \pm 0.2$ & August 2018 \\
\hline Vegetated Runnel & $5.9 \pm 0.2$ & August 2018 \\
\hline Control & $5.2 \pm 0.2$ & October 2018 \\
\hline Sediment Enhancement & $7.3 \pm 0.2$ & October 2018 \\
\hline Soft Sediment Runnel & $6.2 \pm 0.2$ & October 2018 \\
\hline Vegetated Runnel & $5.9 \pm 0.2$ & October 2018 \\
\hline Control & $6.6 \pm 0.1$ & August 2019 \\
\hline Sediment Enhancement & $7.1 \pm 0.1$ & August 2019 \\
\hline Soft Sediment Runnel & $6.4 \pm 0.1$ & August 2019 \\
\hline Vegetated Runnel & $6.2 \pm 0.1$ & August 2019 \\
\hline Control & $6.7 \pm 0.06$ & October 2019 \\
\hline Sediment Enhancement & $7.8 \pm 0.06$ & October 2019 \\
\hline Soft Sediment Runnel & $6.8 \pm 0.09$ & October 2019 \\
\hline Vegetated Runnel & $6.4 \pm 0.06$ & October 2019 \\
\hline
\end{tabular}


Figure 1. Mean percent bare $\pm 1 \mathrm{SE}$ (per $26 \mathrm{~cm}$ diameter plot). Red line represents unvegetated areas (combined open water and bare) in 2014 before the runnels were constructed. Red line only represents previous conditions of runnel and control sites and does not refer to Sediment Enhancement previous conditions.

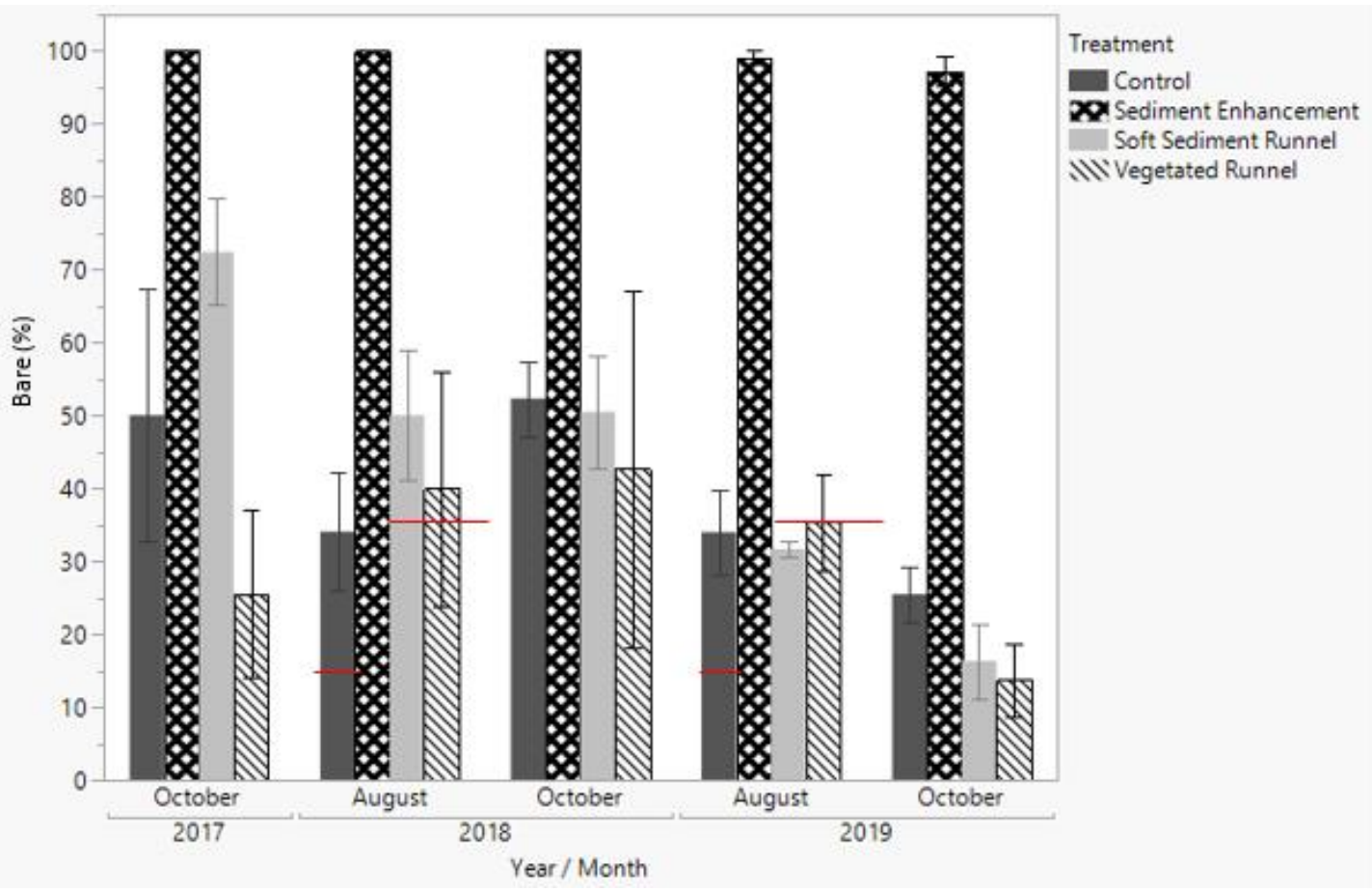


Figure 2. Mean Spartina alterniflora percent cover $+1 \mathrm{SE}$ (per 20cm diameter plot). Pre-Runnel represents the entire runnel area before the runnels were constructed (data collected by Save the Bay).

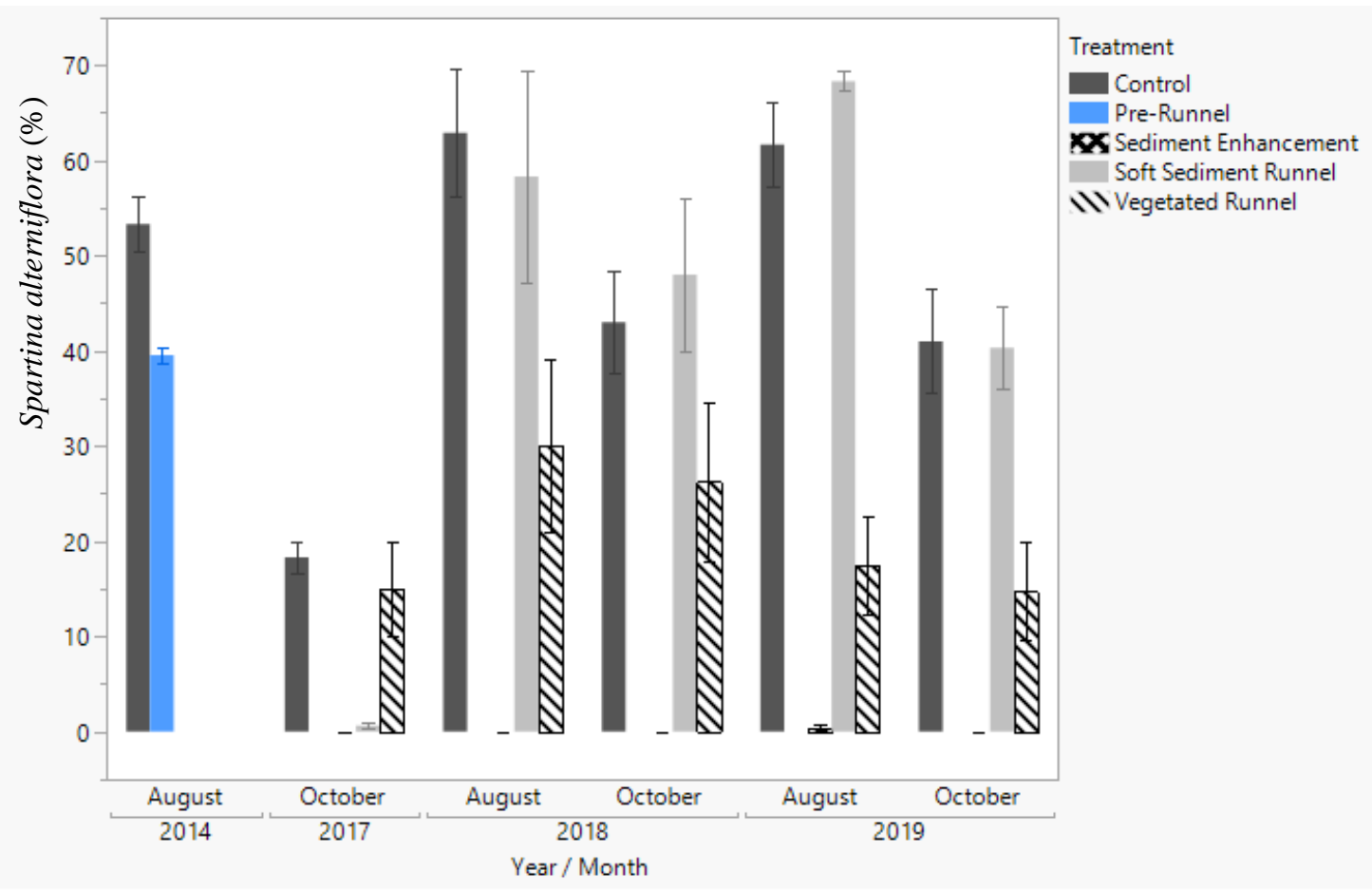


Figure 3. Mean Spartina patens percent cover $+1 \mathrm{SE}$ (per $26 \mathrm{~cm}$ diameter plot). PreRunnel represents the entire runnel area before the runnels were constructed (data collected by Save the Bay).

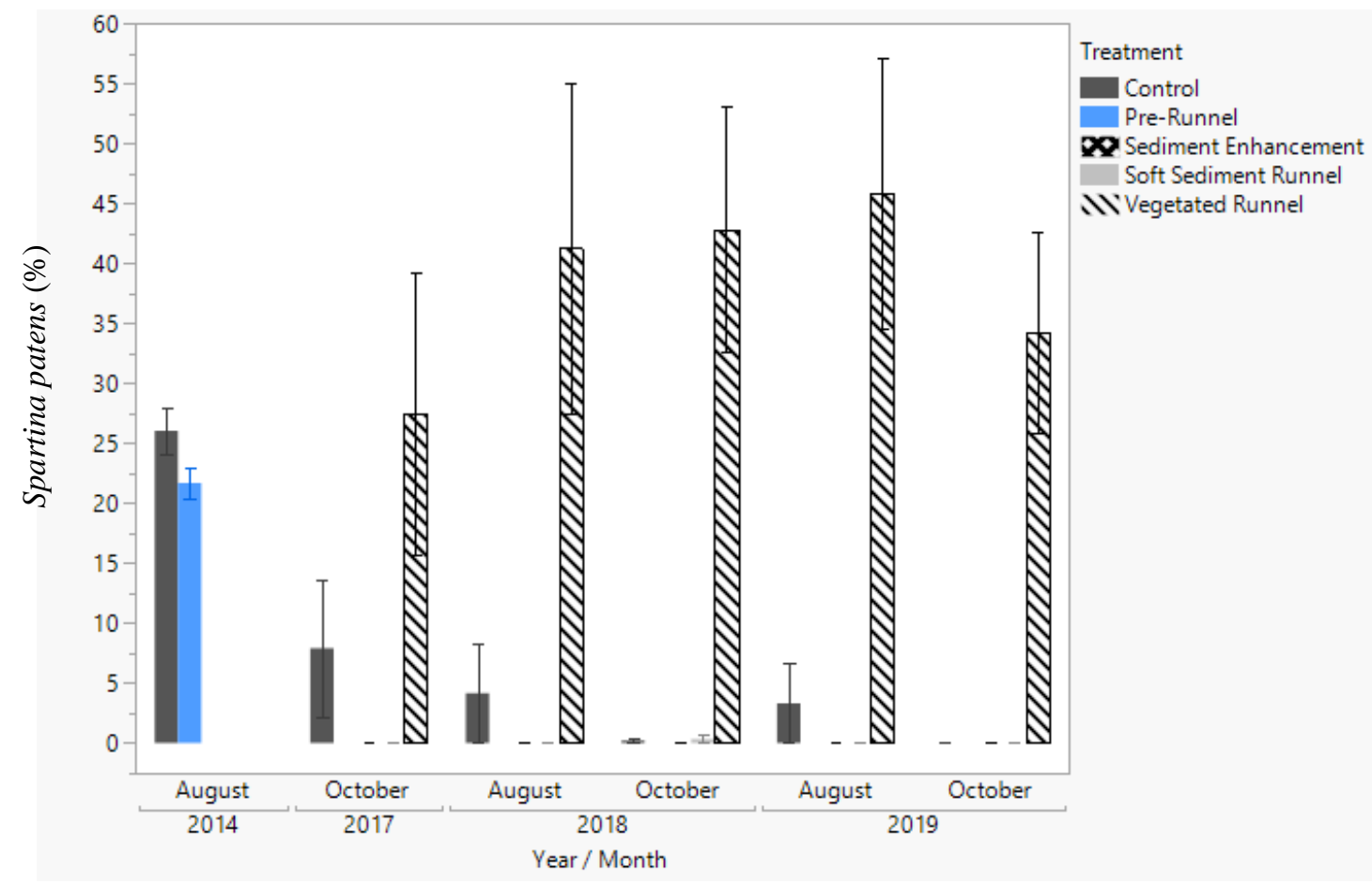


Figure 4. Mean Spartina alterniflora stem density \pm 1 SE (per $26 \mathrm{~cm}$ diameter plot).

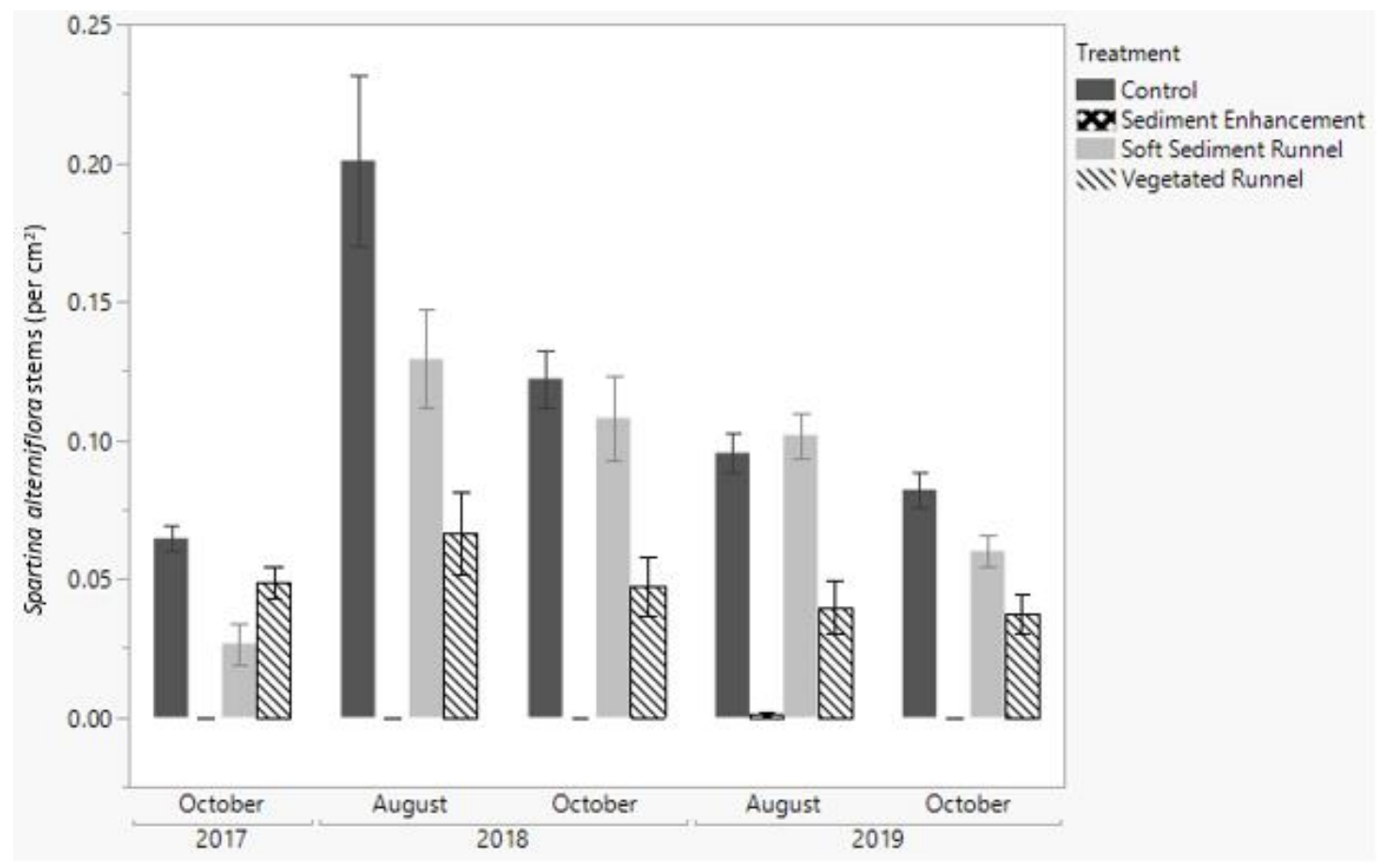


Figure 5. Mean belowground biomass per core \pm 1 SE.

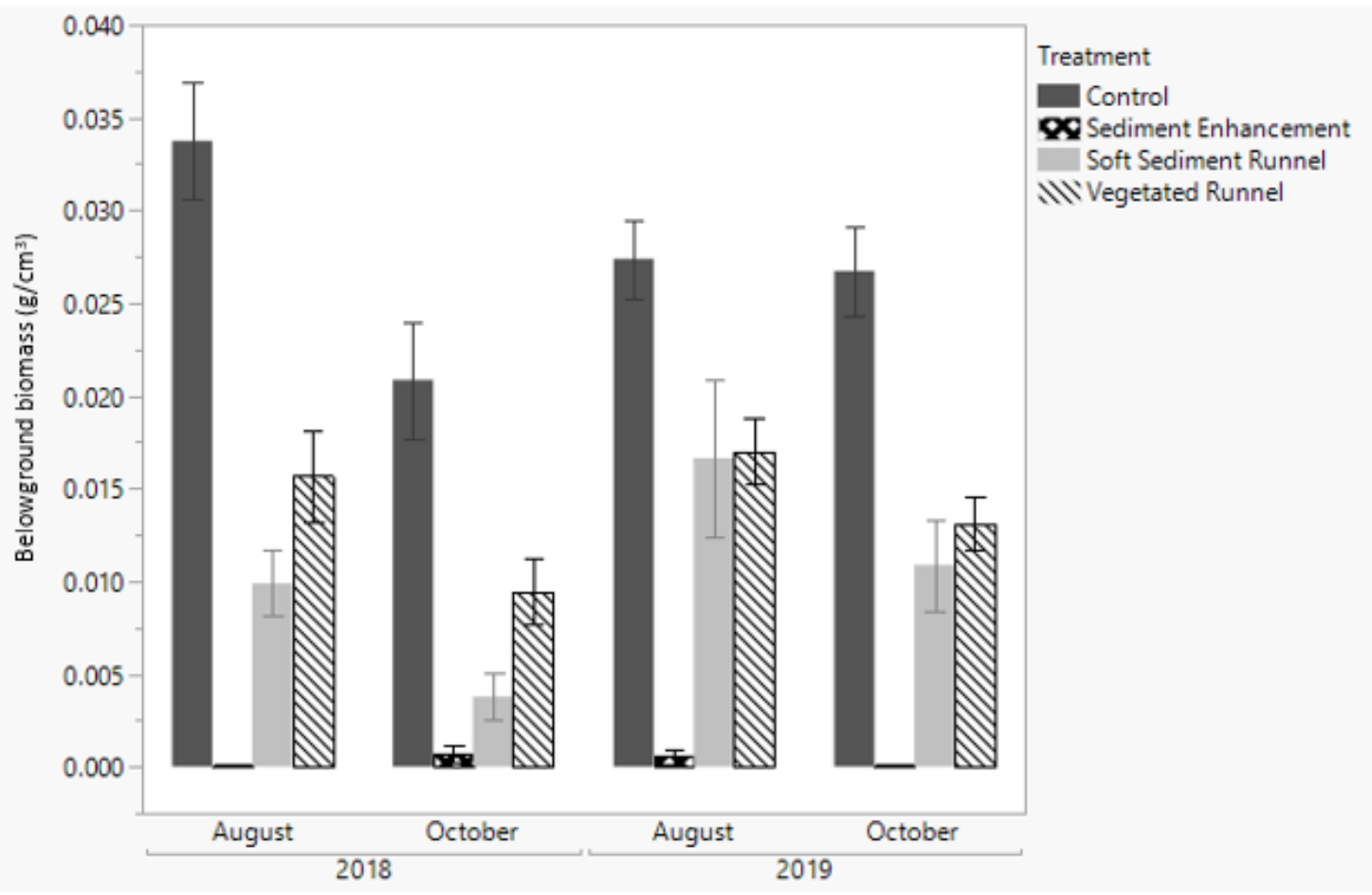


Figure 6. Mean belowground percent organic matter \pm 1 SE.

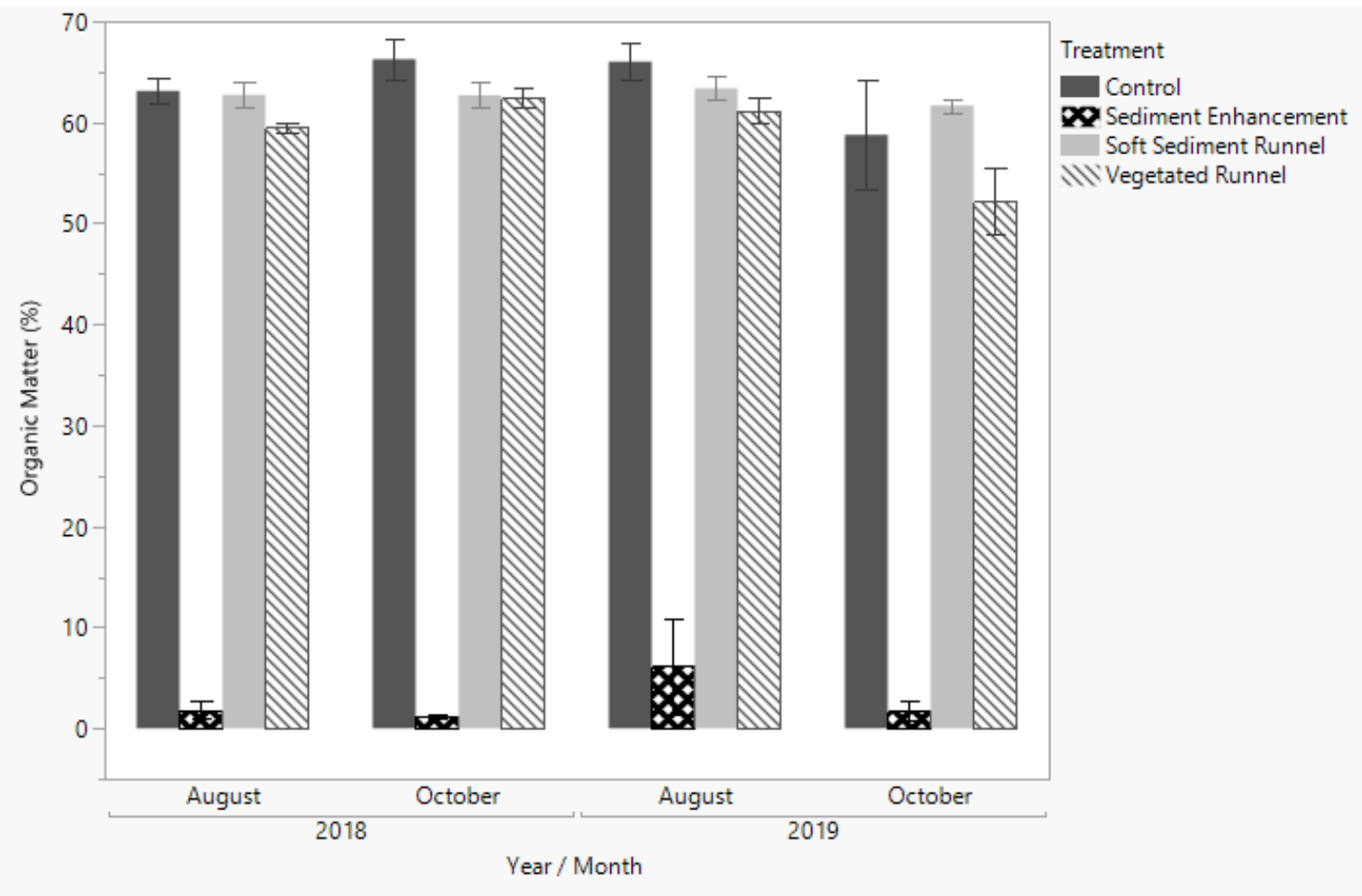


Figure 7. Mean carbon dioxide fluxes per treatment \pm 1 SE. Sediment Enhancement does not have error bars or values if it did not produce significant fluxes at time of collection $\left(\mathrm{R}^{2}<0.9\right)$.

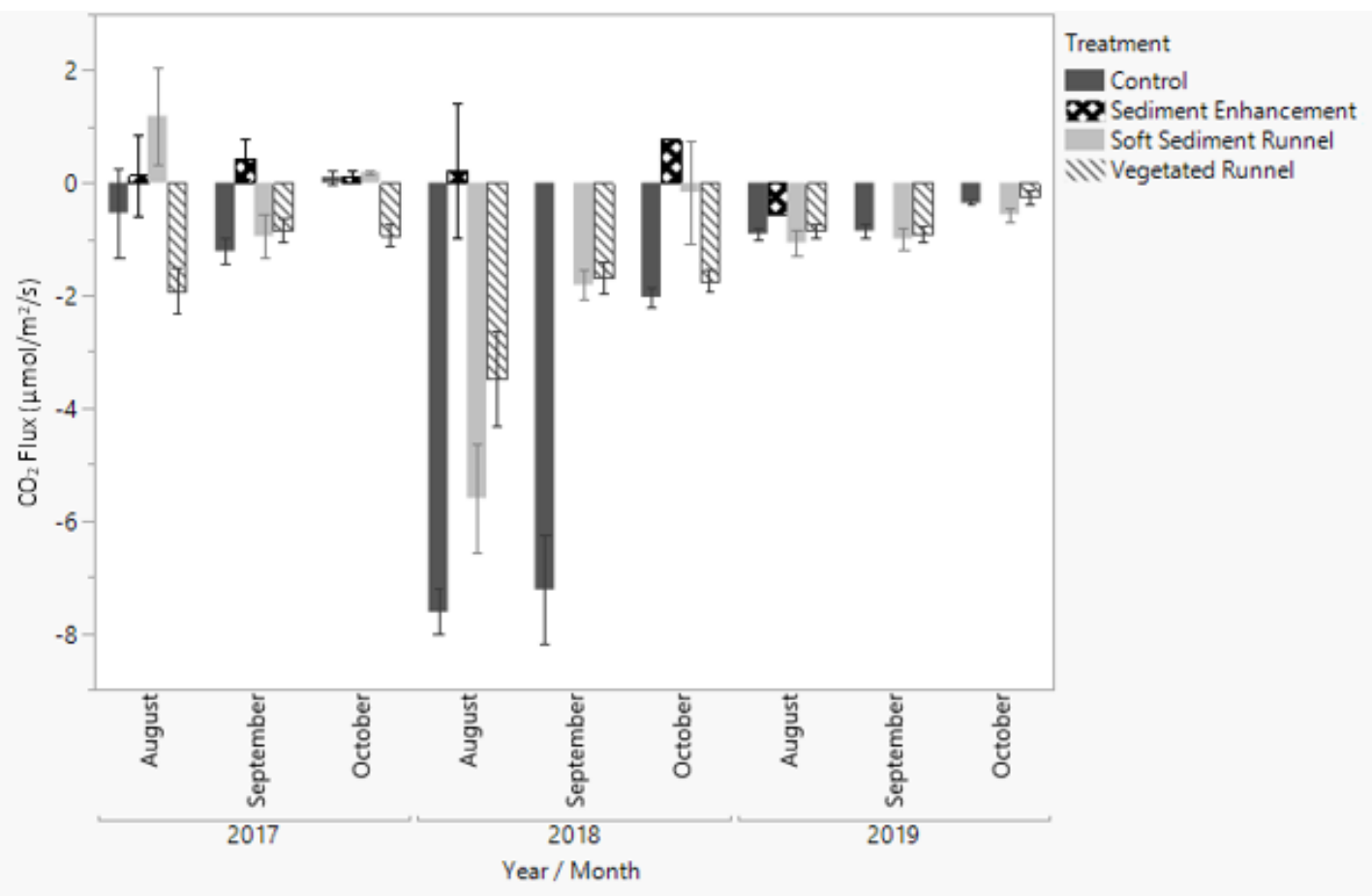




\section{$\underline{\text { References }}$}

Adamowicz, S.C., Roman, C.T., 2005. New England salt marsh pools: A quantitative analysis of geomorphic and geographic features. Wetlands.

https://doi.org/10.1672/4

Alber, M., Swenson, E.M., Adamowicz, S.C., Mendelssohn, I.A., 2008. Salt marsh dieback: An overview of recent events in the US. Estuar. Coast. Shelf Sci. 80, 1-11. https://doi.org/10.1016/j.ecss.2008.08.009

Allen, J.R.L., 1990. The formation of coastal peat marshes under an upward tendency of relative sea-level. J. Geol. Soc. London. https://doi.org/10.1144/gsjgs.147.5.0743

Ashton, A.D., Donnelly, J.P., Evans, R.L., 2008. A discussion of the potential impacts of climate change on the shorelines of the Northeastern USA. Mitig. Adapt. Strateg. Glob. Chang. https://doi.org/10.1007/s11027-007-9124-3

Ball, D.F., 1964. Loss on ignition as an estimate of organic matter and organic carbon in non-calcareous soils. J. Soil Sci. 15, 84-92. https://doi.org/10.1111/j.13652389.1964.tb00247.x

Barbier, E.B., Hacker, S.D., Kennedy, C., Kock, E.W., Stier, A.C., Sillman, B.R., 2011. The value of estuarine and coastal ecosystem services. Ecol. Monogr. 81, 169-193. https://doi.org/10.1890/10-1510.1

Bayard, T.S., Elphick, C.S., 2011. Planning for sea-level rise: Quantifying patterns of saltmarsh sparrow (Ammodramus Caudacutus ) nest flooding under current sea-level conditions . Auk 128, 393-403. https://doi.org/10.1525/auk.2011.10178

Bertness, M.D., 1992. The ecology of a New England salt marsh. Am. Sci. 80, 260 268.

Bertness, M.D., Gough, L., Shumway, S.W., 1992. Salt tolerances and the distribution of fugitive salt marsh plants. Ecology 73, 1842-1851. https://doi.org/10.2307/1940035

Borchert, S.M., Osland, M.J., Enwright, N.M., Griffith, K.T., 2018. Coastal wetland adaptation to sea level rise: Quantifying potential for landward migration and coastal squeeze. J. Appl. Ecol. https://doi.org/10.1111/1365-2664.13169

Boyd, B.M., Sommerfield, C.K., 2016. Marsh accretion and sediment accumulation in a managed tidal wetland complex of Delaware Bay. Ecol. Eng. https://doi.org/10.1016/j.ecoleng.2016.03.045 
Breitfuss, M.J., Connolly, R.M., 2004. Consolidation and volumetric soil-water content of salt marsh soils following habitat modification for mosquito control. Wetl. Ecol. Manag. https://doi.org/10.1007/s11273-004-1783-1

Britton, W.E., 1912. The mosquito plague of the Connecticut coast region and how to control it. Conn. Agric. Exp. Stn. Bull. 173, 3-14.

Cahoon, D.R., Lynch, J.C., Roman, C.T., Schmit, J.P., Skidds, D.E., 2019. Evaluating the relationship among wetland vertical development, elevation capital, sealevel rise, and tidal marsh sustainability. Estuaries and Coasts. https://doi.org/10.1007/s12237-018-0448-x

Carey, J.C., Moran, S.B., Kelly, R.P., Kolker, A.S., Fulweiler, R.W., 2017. The declining role of organic matter in New England salt marshes. Estuaries and Coasts 40, 626-639. https://doi.org/10.1007/s12237-015-9971-1

Corman, S.S., Roman, C.T., King, J.W., Appleby, P.G., 2012. Salt marsh mosquitocontrol ditches: Sedimentation, landscape change, and restoration implications. J. Coast. Res. https://doi.org/10.2112/jcoastres-d-11-00012.1

Crain, C.M., Gedan, K.B., Dionne, M., 2009. Hydrologic alteration of New England tidal marshes by mosquito ditching and tidal restriction. In: Silliman, B.R., Grosholtz, T., Bertness, M.D. (Eds.), Human Impacts on Salt Marshes: A Global Perspective. University of California Press, Berkley, pp. 149-169.

Croft, A.L., Leonard, L.A., Alphin, T., Cahoon, L.B., Posey, M.H., 2006. The effects of thin layer sand renourishment on tidal marsh processes: Masonboro Island, North Carolina. Estuaries and Coasts. https://doi.org/10.1007/BF02786525

Crosby, S.C., Sax, D.F., Palmer, M.E., Booth, H.S., Deegan, L.A., Bertness, M.D., Leslie, H.M., 2016. Salt marsh persistence is threatened by predicted sea-level rise. Estuar. Coast. Shelf Sci. 181. https://doi.org/10.1016/j.ecss.2016.08.018

Dale, P.E., Dale, P.T., Hulsman, K., Kay, B.H., 1993. Runnelling to control saltmarsh mosquitoes: long-term efficacy and environmental impacts. J. Am. Mosq. Control Assoc.

Dale, P.E.R., 2008. Assessing impacts of habitat modification on a subtropical salt marsh: 20 Years of monitoring. Wetl. Ecol. Manag. https://doi.org/10.1007/s11273-007-9058-2

Dale, P.E.R., Chapman, H., Brown, M.D., Ritchie, S.A., Knight, J., Kay, B.H., 2002. Does habitat modification affect oviposition by the salt marsh mosquito, Ochlerotatus vigilax (Skuse) (Diptera: Culicidae)? Aust. J. Entomol. https://doi.org/10.1046/j.1440-6055.2002.00258.x 
Dale, P.E.R., Knight, J.M., 2006. Managing salt marshes for mosquito control: Impacts of runnelling, open marsh water management and grid-ditching in subtropical Australia. Wetl. Ecol. Manag. https://doi.org/10.1007/s11273-005$1113-2$

Deegan, L.A., Johnson, D.S., Warren, R.S., Peterson, B.J., Fleeger, J.W., Fagherazzi, S., Wollheim, W.M., 2012. Coastal eutrophication as a driver of salt marsh loss. Nature 490, 388-392. https://doi.org/10.1038/nature11533

Delaune, R.D., Baumann, R.H., Gosselink, J.G., 1983. Relationships among vertical accretion, coastal submergence and erosion in a Louisiana Gulf Coast marsh. J. Sediment. Petrol. https://doi.org/10.1306/212F8175-2B24-11D7$8648000102 \mathrm{C} 1865 \mathrm{D}$

Emery, N.C., Ewanchuk, P.J., Bertness, M.D., 2018. Competition and salt-marsh plant zonation: Stress tolerators may be dominant competitors Author ( s ): Nancy C. Emery, Patrick J . Ewanchuk and Mark D . Bertness Published by : Wiley on behalf of the Ecological Society of America Stable URL : http://ww 82, 24712485 .

Hanson, A.R., Shriver, W.G., 2006. Breeding birds of northeast salt marshes: Habitat use and conservation. Stud. in Avian Biol. Conserv. 141-154.

Hartig, E.K., Kolker, A.S., Gornit, V.C., 2000. Climate change impacts on saltmarsh morphology in Jamaica Bay, New York City. 11th Int. Peat Congr.

Kozlowski, T.T., 1999. Soil compaction and growth of woody plants. Scand. J. For. Res. https://doi.org/10.1080/02827589950154087

Leonard, L.A., Luther, M.E., 1995. Flow hydrodynamics in tidal marsh canopies. Limnol. Oceanogr. 40, 1474-1484. https://doi.org/10.4319/lo.1995.40.8.1474

Linhoss, A.C., Kiker, G., Shirley, M., Frank, K., 2015. Sea-level rise, inundation, and marsh migration: Simulating impacts on developed lands and environmental systems. J. Coast. Res. 299, 36-46. https://doi.org/10.2112/JCOASTRES-D$13-00215.1$

Macreadie, P.I., Hughes, A.R., Kimbro, D.L., 2013. Loss of "blue carbon" from coastal salt marshes following habitat disturbance. PLoS One 8. https://doi.org/10.1371/journal.pone.0069244

Martin, R.M., Moseman-Valtierra, S., 2017. Different short-term responses of greenhouse gas fluxes from salt marsh mesocosms to simulated global change drivers. Hydrobiologia 802, 71-83. https://doi.org/10.1007/s10750-017-3240-1 
Martin, R.M., Moseman-Valtierra, S., 2015. Greenhouse gas fluxes vary between Phragmites australis and native vegetation zones in coastal wetlands along a salinity gradient. Wetlands 35, 1021-1031. https://doi.org/10.1007/s13157015-0690-y

McLeod, E., Chmura, G.L., Bouillon, S., Salm, R., Björk, M., Duarte, C.M., Lovelock, C.E., Schlesinger, W.H., Silliman, B.R., 2011. A blueprint for blue carbon: Toward an improved understanding of the role of vegetated coastal habitats in sequestering CO2. Front. Ecol. Environ. 9, 552-560. https://doi.org/10.1890/110004

Moseman-Valtierra, S., 2013. Reconsidering climatic roles of marshes: Are they sinks or sources of greenhouse gases?, in: Marshes: Ecology, Management and Conservation.

Moseman-Valtierra, S., Abdul-Aziz, O.I., Tang, J., Ishtiaq, K.S., Morkeski, K., Mora, J., Quinn, R.K., Martin, R.M., Egan, K., Brannon, E.Q., Carey, J., Kroeger, K.D., 2016. Carbon dioxide fluxes reflect plant zonation and belowground biomass in a coastal Marsh. Ecosphere 7. https://doi.org/10.1002/ecs2.1560

Poffenbarger, H.J., Needelman, B.A., Megonigal, J.P., 2011. Salinity influence on methane emissions from tidal marshes. Wetlands 31, 831-842. https://doi.org/10.1007/s13157-011-0197-0

Portnoy, J.W., Valiela, I., 1997. Short-term effects of salinity reduction and drainage on salt-marsh biogeochemical cycling and Spartina (Cordgrass) production. Estuaries. https://doi.org/10.2307/1352615

Reddy, K.R., DeLaune, R.D., 2008. Biogeochemistry of Wetlands: Science and Applications. CRC Press, Boca Raton. https://doi.org/10.1201/9780203491454

Raposa, K.B., Cole Ekberg, M.L., Burdick, D.M., Ernst, N.T., Adamowicz, S.C., 2017a. Elevation change and the vulnerability of Rhode Island (USA) salt marshes to sea-level rise. Reg. Environ. Chang. 17, 389-397. https://doi.org/10.1007/s10113-016-1020-5

Raposa, K.B., Roman, C.T., 2006. Seasonal habitat-use patterns of nekton in a tiderestricted and unrestricted New England salt marsh. Wetlands 21, 451-461. https://doi.org/10.1672/0277-5212(2001)021[0451:shupon]2.0.co;2

Raposa, K.B., Weber, R.L., Ferguson, W., Hollister, J., Rozsa, R., Maher, N., Gettman, A., 2019. Drainage enhancement effects on a waterlogged Rhode Island (USA) salt marsh. Estuar. Coast. Shelf Sci. https://doi.org/10.1016/j.ecss.2019.106435 
Raposa, K.B., Weber, R.L.J., Ekberg, M.C., Ferguson, W., 2017b. Vegetation dynamics in Rhode Island salt marshes during a period of accelerating sea level rise and extreme sea level events. Estuaries and Coasts 40, 640-650. https://doi.org/10.1007/s12237-015-0018-4

Roman, C.T., Jaworski, N., Short, F.T., Findlay, S., Warren, R.S., 2000. Estuaries of the northeastern United States: Habitat and land use signatures. Estuaries. https://doi.org/10.2307/1352997

Sallenger, A.H., Doran, K.S., Howd, P.A., 2012. Hotspot of accelerated sea-level rise on the Atlantic coast of North America. Nat. Clim. Chang. 2, 884-888. https://doi.org/10.1038/nclimate1597

Sebold, K.R. 1998. The low green priaries of the sea: Economic usage and cultural construction of the Gulf of Maine salt marshes. Unpublished PhD diss. University of Maine, Orono.

Slocum, M.G., Mendelssohn, I.A., Kuhn, N.L., 2005. Effects of sediment slurry enrichment on salt marsh rehabilitation: Plant and soil responses over seven years. Estuaries. https://doi.org/10.1007/BF02696063

Smith, D.C., Bridges, A. E., 1982. Salt marsh dykes (dikes) as a factor in eastern Maine agriculture, Maine Historical Society Quarterly, 21, 219-226.

Stein, B.A., Staudt, A., Cross, M.S., Dubois, N.S., Enquist, C., Griffis, R., Hansen, L.J., Hellmann, J.J., Lawler, J.J., Nelson, E.J., Pairis, A., 2013. Preparing for and managing change: Climate adaptation for biodiversity and ecosystems. Front. Ecol. Environ. https://doi.org/10.1890/120277

Tonjes, D.J., 2013. Impacts from ditching salt marshes in the mid-Atlantic and northeastern United States. Environ. Rev. https://doi.org/10.1139/er-2013-0003

Vincent, R.E., Burdick, D.M., Dionne, M., 2013. Ditching and ditch-plugging in New England salt marshes: Effects on hydrology, elevation, and soil characteristics. Estuaries and Coasts. https://doi.org/10.1007/s12237-012-9583-y

Wang, B., Jin, H., Li, Q., Chen, D., Zhao, L., Tang, Y., Kato, T., Gu, S., 2017. Diurnal and seasonal variations in the net ecosystem $\mathrm{CO}_{2}$ exchange of a pasture in the three-river source region of the Qinghai -Tibetan Plateau. PLoS One 12. https://doi.org/10.1371/journal.pone.0170963

Wang, M., He, D., Shen, F., Huang, J., Zhang, R., Liu, W., Zhu, M., Zhou, L., Wang, L., Zhou, Q., 2019. Effects of soil compaction on plant growth, nutrient absorption, and root respiration in soybean seedlings. Environ. Sci. Pollut. Res. https://doi.org/10.1007/s11356-019-05606-z 
Watson, E.B., Wigand, C., Davey, E.W., Andrews, H.M., Bishop, J., Raposa, K.B., 2017. Wetland loss patterns and inundation-productivity relationships prognosticate widespread salt marsh loss for southern New England. Estuaries and Coasts. https://doi.org/10.1007/s12237-016-0069-1

Weston, N.B., 2014a. Declining sediments and rising seas: An unfortunate convergence for tidal wetlands. Estuaries and Coasts 37, 1-23. https://doi.org/10.1007/s12237-013-9654-8

Wigand, C., Ardito, T., Chaffee, C., Ferguson, W., Paton, S., Raposa, K., Vandemoer, C., Watson, E., 2017. A climate change adaptation strategy for management of coastal marsh systems. Estuaries and Coasts 40, 682-693. https://doi.org/10.1007/s12237-015-0003-y

Wilson, B.J., Mortazavi, B., Kiene, R.P., 2015. Spatial and temporal variability in carbon dioxide and methane exchange at three coastal marshes along a salinity gradient in a northern Gulf of Mexico estuary. Biogeochemistry 123, 329-347. https://doi.org/10.1007/s10533-015-0085-4

Zajac, R., Kelly, E., Perry, D., Espinosa, I., 2017. Population ecology of the snail Melampus bidentatus in changing salt marsh landscapes. Mar. Ecol. 38, 1-17. https://doi.org/10.1111/maec.12420 


\section{CHAPTER 3}

SUCCESSFUL IMPLEMENTATION OF ADAPTIVE MANAGEMENT INTO A CLIMATE CHANGE ADAPTATION STRATEGY

Danielle C. Perry ${ }^{1}$, Caitlin Chaffee ${ }^{2}$, Cathleen Wigand ${ }^{3}$, and Carol Thornber ${ }^{1}$

${ }^{1}$ Department of Natural Resources Science, University of Rhode Island, 120 Flagg Road, Kingston, RI, 02881, USA

${ }^{2}$ Coastal Resources Management Council, 4808 Tower Hill, Wakefield, RI, 02879, USA

${ }^{3}$ US EPA ORD CEMM Atlantic Coastal Environmental Sciences Division, 27

Tarzwell Drive, Narragansett, RI, 02882, USA

Manuscript accepted pending revisions to the Journal of Environmental Management 


\begin{abstract}
Due to climate change and other anthropogenic stressors, future conditions and impacts facing coastal habitats are unclear to coastal resource managers. Adaptive management strategies have become an important tactic to compensate for the unknown environmental conditions that coastal managers and restoration ecologists face. Adaptive management requires extensive planning and resources, which can act as a barrier to achieve a successful project. These barriers also create challenges in incorporating adaptive management into climate change adaptation strategies. The Rhode Island Coastal Resource Management Council overcame these challenges and implemented a successful adaptive management approach to restore a drowning salt marsh using the climate adaptation strategy, sediment enhancement, at Quonochontaug Pond in Charlestown, RI. Through effective communication and active stakeholder involvement, this project successfully incorporated interdisciplinary partner and stakeholder collaboration and developed an iterative learning strategy that highlights the adaptive management method.
\end{abstract}




\section{Introduction}

Much research has been conducted on climate change mitigation, but comparatively less attention has focused on implementation of adaptive management strategies to protect environments impacted by climate change (IPCC., 2014). Accelerated relative sea level rise (hereafter referred to as SLR) rates are a major effect of climate change and are a serious threat to coastal environments throughout the Northeast USA (Ashton et al., 2008; Carey et al., 2017; Weston, 2014). New England itself is facing SLR rates that are three or four times the global average (Sallenger et al., 2012). These elevated rates are likely to cause increased flooding, damage to infrastructure in low-lying and coastal areas, decreased resiliency to storms, and loss of coastal wetlands, including salt marshes (Ashton et al., 2008; Wigand et al., 2017). Climate adaptation focuses on enhancing resilience to current and future climate change impacts including SLR, which will help in managing and maintaining coastal ecosystems such as salt marshes (Stein et al., 2013; Wigand et al., 2017).

Climate change and other anthropogenic impacts have lowered the resiliency of Northeast coastal marshes. Salt marshes serve as a carbon sink, food source, breeding habitat, and nursery ground for birds (including the vulnerable salt marsh sparrow, Ammodramus caudacutus), fish, and shellfish (Bayard and Elphick, 2011; Hanson and Shriver, 2006; Raposa and Roman, 2006). These environments also provide flood abatement and help prevent coastal erosion (Barbier et al., 2011; Leonard and Luther, 1995). Historically, lateral transgression and vertical accretion of New England marshes have been able to keep pace with SLR (Raposa et al., 2017; Redfield, 1972). However due to increased coastal development, reduced sediment 
supplies (caused by urbanization, dam construction, and reforestation), and accelerating rates of SLR, marshes are no longer able to migrate or accrete at a rate fast enough to withstand SLR impacts (Sallenger et al., 2012; Weston, 2014; Watson et al., 2017). As a result of these impacts, Northeast marshes, including those in New England, have suffered from increased dieback areas, vegetation loss, peat subsidence, waterlogged soils, and ponding (Hartig et al., 2000; Alber et al., 2008; Raposa et al., 2017). SLR has also exacerbated salt marsh erosion as a result of increased crab burrows in high marsh areas, due to waterlogged soils (Crotty et al., 2017; Raposa et al., 2018). These combined effects further decrease salt marsh resiliency in light of storms and climate change impacts, which the Northeast is particularly susceptible to (Frumhoff et al., 2007; Kirwan and Megonigal, 2013; Crotty et al., 2017).

Climate change adaptation is a management strategy that addresses climaterelated vulnerabilities of susceptible habitats and focuses on preparing for, coping with, and responding to the impacts of current and future system changes (Stein et al., 2013; Wigand et al., 2017). Investing in climate change adaptation projects can increase coastal resiliency to environmental threats and minimize damages (monetary and environmental) from storm events (Narayan et al., 2017; Sutton-Grier et al., 2015) Climate adaptation strategies have been implemented across the U.S. (including living shorelines, green infrastructure, green roofs, flood abatement strategies, irrigation efficiency for agricultural practices, etc.) on the federal, state, local/regional, and private sectors (Bierbaum et al., 2013). One climate adaptation approach to build salt marsh resiliency is sediment enhancement (SE), also known as thin layer deposition where dredged sediment material is added to the salt marsh surface (Cahoon et al., 
2019). The purpose of this technique is to raise the salt marsh platform to an elevation that can withstand future projections of SLR. Although climate adaptation strategies have been adopted nationwide, the incorporation of adaptive management within these projects is uncommon.

Adaptive management incorporates learning-based decision making into management actions (Salafsky et al., 2001; Allen and Gunderson, 2010; Williams, 2011). This strategy is an iterative learning process that allows management actions to proceed despite uncertainty and requires changes in action to improve the management strategy as knowledge and understanding increases (Allen and Gunderson, 2010; Williams, 2011). There is a benefit to this strategy that accounts for uncertain and unexpected responses of a management action, but adaptive management involves challenges that must be overcome. Lack of resources and communication, disorganized coordination and leadership, inherent lack of flexibility within institutions, minimized stakeholder engagement, and action procrastination and avoidance can inevitably lead to adaptive management failure (Adger et al., 2009; Allen and Gunderson, 2011; Bierbaum et al., 2013; McNeeley, 2012). Since adaptive management requires a monitoring component, a larger commitment of time and resources is needed, which can pose an additional challenge. These challenges provide barriers to incorporating adaptive management into climate adaptation projects and require intensive planning to overcome.

The Quonochontaug (Quonnie) project, a state-run and federally funded initiative lead by the Coastal Resource Management Council (CRMC), incorporates the SE climate change adaptation strategy and adaptive management while integrating 
lessons learned from past SE projects. This paper describes the successful incorporation of adaptive management into the Quonnie SE project and highlights the use of collaboration and outreach in restoration initiatives. We discuss how adaptive management components: 1) Create a project model 2) Establish a clear and common purpose/action 3) Develop and implement a management and monitoring plan 4) Analyze results and iterate 5) Communicate results, were applied for the successful implementation of the Quonnie climate change adaptation project (Salafsky et al., 2001).

\section{Quonochontaug (Quonnie) sediment enhancement project overview}

Quonnie Pond is located along the southern coast of RI, in the towns of Charlestown and Westerly. SLR impacts caused degradation and drowning of salt marsh areas within Quonnie pond and other parts of southern New England (Watson et al., 2017). The purpose of the SE project was to restore 30 acres of salt marsh habitat and improve tidal flushing and increase eelgrass habitat via dredging, create conditions and elevations suitable of targeted vegetation species, and to improve salt marsh resiliency to SLR and climate change impacts. Dredging improved recreational access to the Pond by removing sediment that hinders navigation and limits water recreation.

3. Establishing the climate change adaptation project: Identifying stakeholders and partners

3.1 Establishing the salt marsh climate change adaptation and adaptive management team 
For the Quonnie sediment enhancement adaptive management (Q-SEAM) project, the initial goal was to gather together organizations and people dedicated to salt marsh protection, including agencies experienced in assessing salt marsh vulnerability and condition and implementing restoration actions. This required the expertise of federal, state, and local agencies, as well as non-profit and nongovernment organizations (NGOs); all held specific roles and responsibilities (Table 1). The creation of this team occurred during the stage of initial assessment of salt marsh condition, prior to the SE implementation.

\subsection{Initial salt marsh condition assessment}

Rhode Island follows the Salt Marsh Monitoring and Assessment Program (SMMAP) (Raposa et al., 2016). SMAPP monitoring helped identify the degrading marsh conditions and provided the necessary data to support the SE initiative at the Quonnie Pond site (Figure 1). This monitoring involved the rapid assessment of marsh conditions with marsh site visits across the state. Monitoring showed an abundance of

ponding and vegetation die-off areas and the displacement of high marsh plants by low marsh plant species within the Quonnie salt marsh (Cole Ekberg et al., 2017; Kutcher, 2019). This site was also identified to have relatively low surface elevation within the tidal frame and was characterized as an area of high disturbance (i.e. high density of human-made ditches, crab burrows, and edge erosion) (Kutcher, 2019).

The Sea Level Affecting Marshes Model (SLAMM) simulates the response of salt marsh areas to varying SLR rate scenarios (SLAMM, 2009). Results of the SLAMM model simulations help evaluate marsh migration potential and prioritize appropriate marsh adaption and restoration efforts (Cole Ekberg et al., 2017; Wigand 
et al., 2017). The Quonnie SLAMM results predicted significant marsh loss with $1 \mathrm{~m}$ of SLR within the next 40-50 years and recognized limited potential for salt marsh migration

(http://www.crmc.ri.gov/maps/maps_slamm/20150331_RISLAMM_Summary.pdf). These results and the SMMAP monitoring helped determine the SE treatment as an appropriate climate adaptation strategy for this site.

\section{Quonnie sediment enhancement adaptive management project}

\subsection{Quonnie project model}

Iteration is a major theme in adaptive management; Q-SEAM incorporated methods and lessons learned from a previous SE project at Ninigret Pond in Charlestown, RI. Q-SEAM adapted the same Before, After, Control, Impact (BACI) experimental design model as the Ninigret project, where the control (area where no management action took place) and impact (sediment enhancement) sites were monitored before and after treatment (Smith, 2014). The model incorporated monitoring that would occur for at least five years after sediment placement. It was hypothesized that the control would show signs of degradation (displacement of high marsh plants by low marsh plants, increase in vegetation die-off areas, loss of soil organic carbon, loss of habitat value) over time, while the impact area would gradually recolonize vegetation and nekton communities and accumulate soil organic matter over the five-year monitoring period. Project targets and metrics (Table 2) were incorporated into the BACI model to guide learning. To optimize results and enhance the project, communication, construction, and monitoring techniques learned from the Ninigret project were incorporated in the Q-SEAM plans (Table 3). Results learned 
from the BACI monitoring and analyses would inform future decision making for Quonnie maintenance as well as future SE projects.

Important stakeholder communication techniques and construction and field strategies were learned and adapted for Q-SEAM to help gain project support and improve management strategies (Table 3). For example, dredging methods used at

Ninigret were altered and improved for the Quonnie project (RTK mounted equipment and amphibious and low ground pressure equipment). Earlier monitoring at Ninigret taught the Q-SEAM team that intensive post-construction sediment grading (to ensure target elevations were met and establish drainage) was needed, that geese would use the area for foraging, and that excessive wind and sediment movement could impact the target elevations. By being aware of these potential issues, Q-SEAM project managers were able to incorporate actions (i.e. goose fencing; beach grass and dune fencing placement for wind protection and sediment stabilization) into the management plan, which were expected to have positive results on maintaining target elevations and subsequent plant colonization.

\subsection{Establish a common purpose/action}

An important initial adaptive management step was to create a clear project mission that was discussed and agreed upon by all stakeholders. Addressing and recognizing stakeholder goals early on helped to avoid future complications, and it held the partners accountable and committed to their project responsibilities. While addressing the major goals of the project stakeholders, the mission statement was manageable and conveyed realistic expectations (Figure 2). CRMC leaders ensured they were clear and forthcoming about the roles of each stakeholder, the logistics of 
the project and their impacts on stakeholders' goals, which helped to manage stakeholder expectations. CRMC went through a negotiation process with the Town of Charlestown and the Salt Ponds Coalitions before agreeing on the amount of sediment to be dredged. Although concessions and compromises were made (Town of Charlestown provided more funds to dredge additional sediment and determined the dredging areas), CRMC ensured that the stakeholders' needs were heard and considered, which further helped to establish trust and commitment amongst the stakeholders and partners.

\subsection{Development and implementation of a management and monitoring plan}

CRMC and the monitoring partners collaborated to create the Quonnie Quality Assurance Project Plan (QAPP), which included a flexible management and monitoring plan that allowed for learning and monitoring plan adjustments, highlighting the adaptive management approach. The QAPP included project targets and metrics such as elevation, vegetation community, and wildlife community (Table 2) and methods to assess these targets. Monitoring these targets was essential to evaluate marsh function and restoration progress as well as for the learning needed to support future decision-making and management plan adjustments.

CRMC sought partner and stakeholder feedback and input throughout the development of the adaptive management plan via meetings and public presentations to municipal commissions. This allowed for stakeholders to voice concerns and identify issues early, and for the project team to address them in a manner that aligned with the project's goals and targets. CRMC maintained open and frequent communication with the project stakeholders, and shared project designs and plans as 
they were developed. This transparency built trust with the stakeholders, and also allowed CRMC to address concerns early and rectify issues to prevent future conflict.

Having a clear management and construction plan to convey to the dredging company, J. F. Brennan Company, Inc. (hereafter J. F. Brennan), helped with communication and collaboration. CRMC ensured that the construction plans for J. F. Brennan were detailed enough for design implementation, but were flexible enough to incorporate contractor expertise and methodologies. CRMC and J. F. Brennan went through an iterative process throughout construction, where adjustments to the construction plan and design were made as necessary and as the project progressed. J. F. Brennan appreciated having their inputs valued. One of the lead constructors in an interview said, "They [CRMC] look to us for ideas and value our opinion...the process is made easier because they are open and upfront." Establishing two-way communication between hired contractors, where contractors' ideas and expertise were respected, considered, and incorporated, enhanced the outcome of Q-SEAM and highlights the learning/adaptive component of adaptive management.

The monitoring plan was helpful in establishing goals and parameters as well as the responsibilities of each partner, which in turn kept the partners accountable. Monitoring occurred during the peak growing season, between mid-August and midSeptember before sediment placement and the first season after placement and was intended to continue for four additional growing seasons thereafter. Monitoring partner meetings were held before each salt marsh growing season to discuss the parameters that would be measured, monitoring methods, and timelines as well as a meeting after the growing season to discuss monitoring results and adjustments for the 
next season. Meetings were then scheduled as needed throughout the growing season to address unexpected issues and adjustments to the original monitoring/management plans. Outside of these meetings, the monitoring partners were in open and continuous communication to address questions as they arose.

\subsection{Analyze results and iterate}

As data was interpreted and field conditions became clearer, CRMC and partners had to adapt and learn from unexpected challenges, which sometimes called for adjustments to the QAPP and data collection methods. For example, the Quonnie site was more accessible than previous SE sites and civilians used the area as a recreational space. In response to this, signage and fencing were placed on the borders of the site and a separate area was designated as a recreational location (Figure 3a \&b). Monitoring changes were needed as well, which included adjusted $\mathrm{pH}$ and soil salinity sampling methods due to the low moisture content of the dredge material. During construction, the Q-SEAM team learned that the use of one dredge versus two dredges would make the handling/distribution of dredge material more manageable and prevent sediment buildup. As adaptive management calls for, management and monitoring plans were adjusted accordingly as this new information arose. The flexibility of each monitoring partner and efficient communication allowed for quick responses to these unexpected outcomes and adjustments to original methods.

\subsection{Communicate results}

The Q-SEAM monitoring data were made available throughout the monitoring process to provide transparency, cultivate public engagement, and provide project updates, via the CRMC ArcGIS Online Quonochontaug Data Gallery 
(https://crmcgis.maps.arcgis.com/apps/MinimalGallery/index.html?appid=bfda4d3673

3c43fa93874e09414457e4). The CRMC communicated SE project results through regional conference presentations and site visits with the community and regional agencies, and is currently developing supplemental material such as restoration guidance and lessons learned documents. Making information readily available helped maintain public involvement and interest in the project as well as educated other agencies that were interested in learning more about the SE restoration technique. Agencies including NBNERR and EPA Atlantic Coastal Environmental Sciences

Division, communicate with other NERRs and EPA facilities across the country to help to further develop SE best practices and apply them to other sites.

\section{Community outreach and engagement}

Throughout the Quonnie project, outreach and community engagement was a continuous priority. During the early stages of the project, Charlestown members were brought in for site visits, and CRMC presented SE plans at town council meetings to help gain support for the project and improve understanding of the project's purpose. A Quonnie planting event, organized and facilitated by Save the Bay, was one of the largest outreach initiatives that occurred after sediment placement in the early spring of 2019. This event brought together school groups, Save the Bay volunteers as well as volunteers from various town organizations, project stakeholders and partners, and Charlestown citizens. Planting events allowed citizen volunteers to make a physical contribution and connection to the project (Figure 3c \&d). CRMC sponsored short promotional videos to highlight the restoration that occurred in the state (http://www.crmc.ri.gov/). The Salt Ponds Coalition published an article about the 
project in its newsletter, Tidal Page, as well as produced videos focused on the SE projects within the state. CRMC and monitoring partners continue to present at local, regional and national meetings to share their experiences and results with the SE technique.

\section{Conclusions}

The Q-SEAM project demonstrated that effective collaboration, efficient communication, community involvement, and outreach were necessary to overcome adaptive management challenges and achieve success. Collaboration was an integral part of the adaptive management approach as the Quonnie project required the expertise of multiple disciplines. Partnership and collaboration came with benefits including resource and cost sharing, division of responsibilities, development of management plans, and implementation of monitoring. However, challenges were associated with collaboration, which CRMC was able to overcome with frequent and open communication with partners, and guided, productive monitoring and project meetings. The partners established and held similar goals, which led to accountability, commitment, and timely follow through with actions.

Community involvement and outreach were instrumental components of the QSEAM project. Therefore, establishing trust and actively involving the community in the adaptive management approach was essential for the success of the project. CRMC operated under full transparency with the Town of Charlestown and other stakeholders, addressing their concerns early on and managing expectations. Establishing trust early with the stakeholders, through site visits, town and project planning meetings, was essential to gain stakeholder support and assistance. Involving 
the community throughout the project grants the public an invested interested in its success.

Rhode Island's successful use of an adaptive management strategy to implement the SE climate change adaptation project is expected to influence future decision-making on coastal marsh restoration in the Northeast USA and beyond. An adaptive management strategy is a valuable tool due to its flexible nature that accounts for unexpected results and adjustable management and monitoring plans.

Incorporating adaptive management strategies within climate change adaptation and resiliency projects becomes increasingly important as climate change progresses and future conditions are more uncertain.

\section{Acknowledgements}

Funding: Implementation of sediment enhancement project was supported by the NOAA Coastal Resilience Grants (FFO \#: NOAA-NOS-NRPO-2017-2005159), Town of Charlestown, and Salt Ponds Coalition. Research also supported by National Science Foundation Graduate Research Fellowship (grant number DGE-1747454; awarded to Danielle Perry).

We would like to thank all monitoring partners and stakeholders of the Quonnie Project. Special thanks to Save the Bay’s W. Ferguson and D. Prescott for construction and field location oversite. 
Figure 1. Describes agencies' roles in the initial assessment and proposal development of the Q-SEAM project.

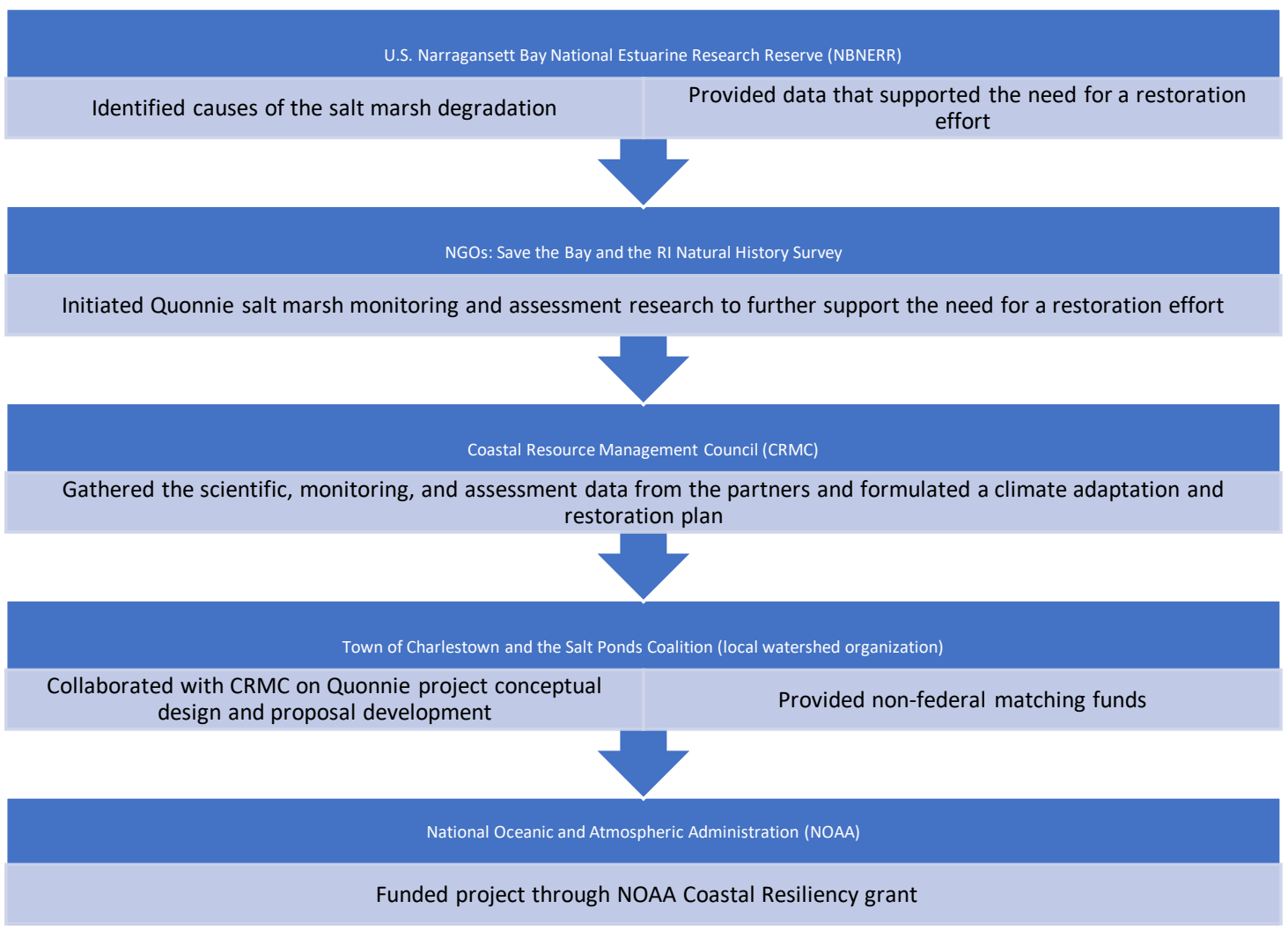


Figure 2. Describes the main goals of the project stakeholders and the derived overall project mission.

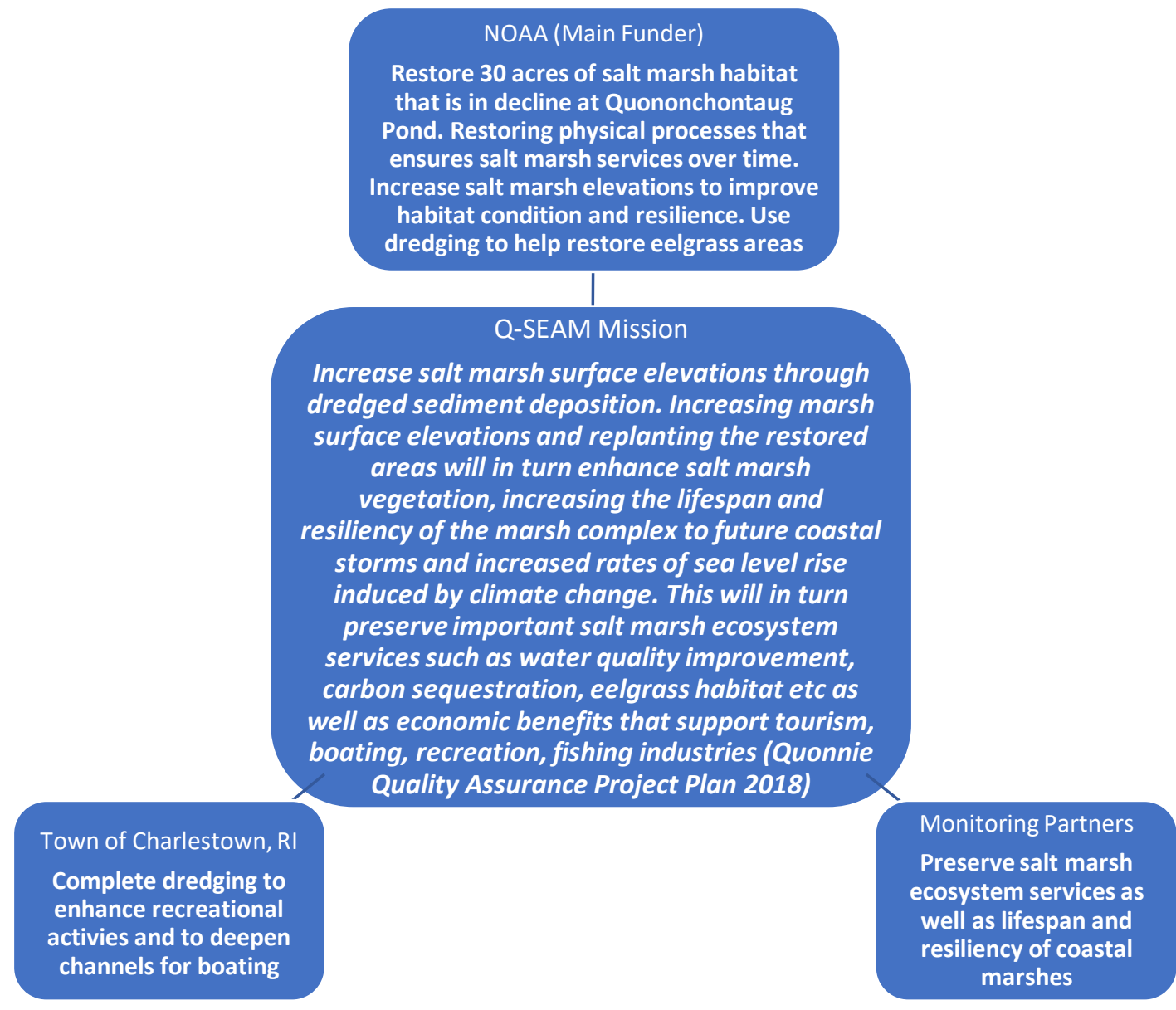


Figure 3. A. Signage placed at Quonnie restoration site B. Designated recreational area for civilians at the Quonnie restoration site. C \& D. Quonnie salt marsh planting community event
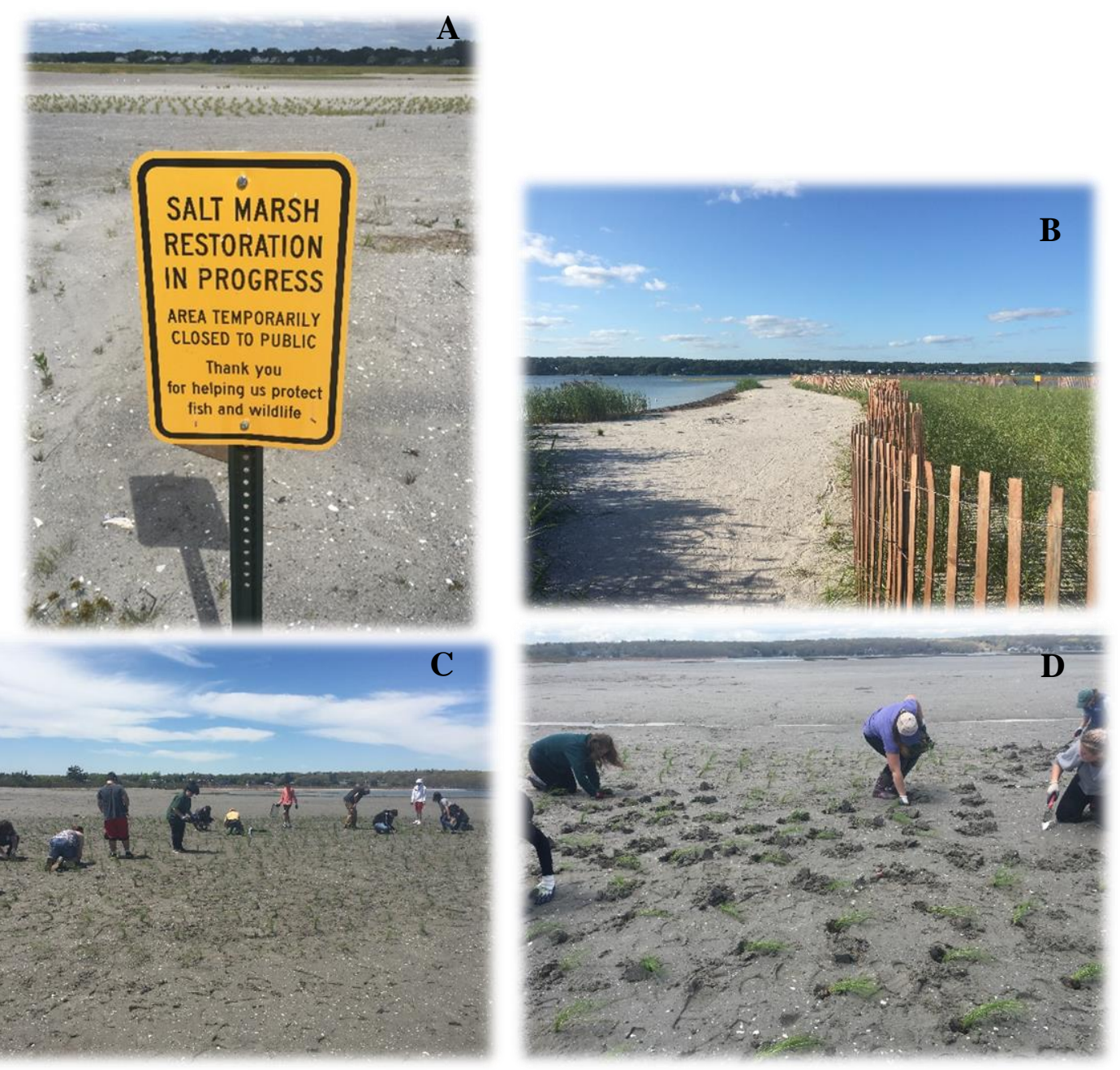
Table 1. Partners, stakeholders, and decision-makers and their roles for the Quonnie sediment enhancement project

\begin{tabular}{|c|c|c|}
\hline Stakeholders & Agency Type & Role of Partners \\
\hline $\begin{array}{l}\text { Coastal Resource Management } \\
\text { Council (CRMC) }\end{array}$ & State & $\begin{array}{l}\text { Lead and supervisory } \\
\text { organization; Responsible for } \\
\text { planning and implementation of } \\
\text { the project; Performed dredge } \\
\text { sediment testing for hazardous } \\
\text { material; Applied for funding, } \\
\text { permitting; } \\
\text { Legal responsibility; Organizer } \\
\text { of stakeholder meetings; } \\
\text { Executed and managed contracts } \\
\text { for construction, planting, } \\
\text { adaptive management and } \\
\text { monitoring }\end{array}$ \\
\hline $\begin{array}{l}\text { RI Department of } \\
\text { Environmental Management }\end{array}$ & State & $\begin{array}{l}\text { Property owner, manager of } \\
\text { public fishing and boating } \\
\text { access, permitting entity, } \\
\text { provided equipment for post- } \\
\text { construction excavation (Office } \\
\text { of Mosquito Abatement). }\end{array}$ \\
\hline Town of Charlestown & State & $\begin{array}{l}\text { Dredge permit applicant, } \\
\text { provided non-federal match } \\
\text { funding, some technical and } \\
\text { conceptual design assistance, } \\
\text { coordination with Harbor Master } \\
\text { and Police Department re: public } \\
\text { safety during construction }\end{array}$ \\
\hline $\begin{array}{l}\text { National Oceanic and } \\
\text { Atmospheric Administration } \\
\text { (NOAA) }\end{array}$ & Federal & $\begin{array}{l}\text { Lead funder from NOAA } \\
\text { Coastal Resilience Grants (FFO } \\
\text { \#: NOAA-NOS-NRPO-2017- } \\
\text { 2005159) }\end{array}$ \\
\hline $\begin{array}{l}\text { National Fish and Wildlife } \\
\text { Foundation }\end{array}$ & Federal & $\begin{array}{l}\text { Funder; Award from Hurricane } \\
\text { Sandy Coastal Resiliency } \\
\text { Program (leveraged federal } \\
\text { construction funding) }\end{array}$ \\
\hline Salt Ponds Coalition & $\begin{array}{l}\text { Non- } \\
\text { Governmental } \\
\text { Watershed }\end{array}$ & $\begin{array}{l}\text { Provided non-federal matching } \\
\text { funds, public outreach and }\end{array}$ \\
\hline
\end{tabular}




\begin{tabular}{|c|c|c|}
\hline & $\begin{array}{l}\text { Organization } \\
(\mathrm{NGO})\end{array}$ & $\begin{array}{l}\text { education, letters of support for } \\
\text { funding application }\end{array}$ \\
\hline J. F. Brennan Company, Inc. & Contractor & $\begin{array}{l}\text { Contractor for dredging and } \\
\text { placement of material }\end{array}$ \\
\hline \multicolumn{3}{|c|}{ Monitoring Partners } \\
\hline $\begin{array}{l}\text { Save The Bay (Narragansett } \\
\text { Bay) }\end{array}$ & $\begin{array}{l}\text { Non-profit, } \\
\mathrm{NGO}\end{array}$ & $\begin{array}{l}\text { Construction oversite, } \\
\text { Vegetation monitoring; Habitat } \\
\text { restoration expertise; Volunteer } \\
\text { coordination; Planting; Adaptive } \\
\text { management in coordination } \\
\text { with RIDEM }\end{array}$ \\
\hline $\begin{array}{l}\text { Rhode Island Natural History } \\
\text { Survey }\end{array}$ & NGO & $\begin{array}{l}\text { Initial MarshRAM site } \\
\text { assessment of salt marsh } \\
\text { condition (pre-dredge } \\
\text { placement); Monitoring of } \\
\text { vegetation community recovery } \\
\text { and rare plant species }\end{array}$ \\
\hline $\begin{array}{l}\text { Environmental Protection } \\
\text { Agency, Atlantic Ecology } \\
\text { Division }\end{array}$ & Federal & $\begin{array}{l}\text { Soils monitoring; Technical } \\
\text { support on salt marsh } \\
\text { monitoring and assessment; } \\
\text { Consulted through US Army } \\
\text { Core of Engineers permit } \\
\text { process. }\end{array}$ \\
\hline $\begin{array}{l}\text { University of Connecticut's } \\
\text { Saltmarsh Habitat and Avian } \\
\text { Research Program }\end{array}$ & $\begin{array}{l}\text { Educational } \\
\text { Institution }\end{array}$ & Avian monitoring \\
\hline $\begin{array}{l}\text { University of Rhode Island } \\
\text { Environmental Data Center }\end{array}$ & $\begin{array}{l}\text { Educational } \\
\text { Institution }\end{array}$ & $\begin{array}{l}\text { Elevation monitoring; } \\
\text { Hydrology monitoring; } \\
\text { Acquisition of Unmanned Aerial } \\
\text { Systems (drone) imagery; } \\
\text { Development of ArcGIS online- } \\
\text { based project data portal }\end{array}$ \\
\hline
\end{tabular}


Table 2. Monitoring targets for Quonnie sediment enhancement project

\begin{tabular}{|ll|}
\hline Monitoring Metric & Target/ Monitoring Goals \\
\hline Saltmarsh habitat restored & 30 acres \\
$\begin{array}{l}\text { Low marsh plant community elevation } \\
\text { range }\end{array}$ & 3 acres \\
$\begin{array}{l}\text { High marsh plant (Spartina patens, } \\
\text { Juncus gerardii, Distichlis spicata) } \\
\text { community elevation range }\end{array}$ & $0.15-0.23 \mathrm{~m}(0.5-0.75 \mathrm{ft}$ NAVD88) \\
$\begin{array}{l}\text { Iva frutescens community elevation range } \\
\text { Nekton species }\end{array}$ & $\begin{array}{l}0.38-0.53 \mathrm{~m} \text { (1.25-1.75ft NAVD88) } \\
\text { Summer flounder, winter flounder, }\end{array}$ \\
& $\begin{array}{l}\text { Striped bass, river herring, menhaden, } \\
\text { tautog, American eel, bluefish, and } \\
\text { scup }\end{array}$ \\
\hline
\end{tabular}


Table 3. Communication tips for working with the town, public, and other stakeholders

1. Make clear how the project's goals align with their goals

2. Avoid the use of jargon and use terms they are familiar with

3. Explain how the project will benefit them. Relate the project to issues they care about.

4. When speaking with legislature, highlight how the project will address public health and safety

5. Listen to and address concerns. Make their voices and needs heard, which helps to establish trust.

6. Engage the community throughout the process with site visits, updates, and town meetings.

7. Communicate often with stakeholders and partners with meetings and updates 
Table 4. Permits needed for the 30-acre Quonnie sediment enhancement dredge project

\begin{tabular}{|ll|}
\hline Agency Issued & Permit \\
\hline US Army Corps of Engineers & $\begin{array}{l}\text { Section 404 Category II General } \\
\text { Permit }\end{array}$ \\
RI Department of Environmental & $\begin{array}{l}\text { Dredging Permit (includes Section } \\
\text { Management }\end{array}$ \\
Coastal Resource Management Council & Dredging Permity / Coastal Assent \\
NOAA served as lead federal agency & $\begin{array}{l}\text { National Environmental Policy Act } \\
\text { (NEPA) Compliance (includes sign- } \\
\text { off from State and Tribal Historic } \\
\text { Preservation Officers) }\end{array}$ \\
\hline
\end{tabular}


Table 5. Quonnie and Ninigret timeline of major events and project progression.

August 2011- Salt marsh condition assessment by Save The Bay

September 2012- Meeting with National Park Service about Jamaica

Bay Thin Layer Deposition Project (Big Egg)

2013- Meetings with town, Salt Ponds Coalition and partners;

Ninigret funding proposal development

May 2013- Funding proposal submitted for Ninigret construction,

Quonnie design

July 2013- Site visit to Ninigret and Quonochontaug (Quonnie) with

partners

January 2014- Regional thin layer deposition meeting on Long Island

October 2014- Ninigret award accepted

August 2015- Ninigret pre-restoration monitoring

September 2015- Ninigret consultant contracted for permitting and design

December 2016- Ninigret project designed, permitted and implemented

2017- Quonnie designs developed; Project team meetings for design review; Quonnie permit applications developed

July 2017- Applied for NOAA funding for Quonnie construction

November 2017- NOAA funding awarded

2018- Quonnie permits received 
June 2018- Request for Proposal (RFP) issued for Quonnie construction work

August 2018- Quonnie pre-restoration monitoring

October 2018- Quonnie contractor hired, contract executed

November 2018- Mobilization of dredging equipment at Quonnie

December 2018- Quonnie dredging and placement

January 2019- Demobilization of dredging equipment at Quonnie;

Quonnie As-built surveys

March 2019- Post-construction adaptive management (excavation to

ensure target elevations; drainage establishment)

May 2019- Quonnie planting event

August 2019- Quonnie post-restoration monitoring

Monitoring Activity

Outreach and Coordination Activity

Project Implementation Activity 


\section{References}

Adger, W.N., Dessai, S., Goulden, M., Hulme, M., Lorenzoni, I., Nelson, D.R., Naess, L.O., Wolf, J., Wreford, A., 2009. Are there social limits to adaptation to climate change? Clim. Change. https://doi.org/10.1007/s10584-008-9520-z

Alber, M., Swenson, E.M., Adamowicz, S.C., Mendelssohn, I.A., 2008. Salt Marsh Dieback: An overview of recent events in the US. Estuar. Coast. Shelf Sci. 80, 1-11. https://doi.org/10.1016/j.ecss.2008.08.009

Allen, C.R., Gunderson, L.H., 2011. Pathology and failure in the design and implementation of adaptive management. J. Environ. Manage. https://doi.org/10.1016/j.jenvman.2010.10.063

Ashton, A.D., Donnelly, J.P., Evans, R.L., 2008. A discussion of the potential impacts of climate change on the shorelines of the Northeastern USA. Mitig. Adapt. Strateg. Glob. Chang. https://doi.org/10.1007/s11027-007-9124-3

Barbier, E.B., Hacker, S.D., Kennedy, C., Kock, E.W., Stier, A.C., Sillman, B.R., 2011. The value of estuarine and coastal ecosystem services. Ecol. Monogr. 81, 169-193. https://doi.org/10.1890/10-1510.1

Bayard, T.S., Elphick, C.S., 2011. Planning for Sea-level Rise: Quantifying Patterns of Saltmarsh Sparrow ( Ammodramus Caudacutus ) Nest Flooding Under Current Sea-level Conditions . Auk 128, 393-403. https://doi.org/10.1525/auk.2011.10178

Bierbaum, R., Smith, J.B., Lee, A., Blair, M., Carter, L., Chapin, F.S., Fleming, P., Ruffo, S., Stults, M., McNeeley, S., Wasley, E., Verduzco, L., 2013. A comprehensive review of climate adaptation in the United States: More than before, but less than needed. Mitig. Adapt. Strateg. Glob. Chang. https://doi.org/10.1007/s11027-012-9423-1

Cahoon, D.R., Lynch, J.C., Roman, C.T., Schmit, J.P., Skidds, D.E., 2019. Evaluating the Relationship Among Wetland Vertical Development, Elevation Capital, Sea-Level Rise, and Tidal Marsh Sustainability. Estuaries and Coasts. https://doi.org/10.1007/s12237-018-0448-X

Carey, J.C., Moran, S.B., Kelly, R.P., Kolker, A.S., Fulweiler, R.W., 2017. The Declining Role of Organic Matter in New England Salt Marshes. Estuaries and Coasts 40, 626-639. https://doi.org/10.1007/s12237-015-9971-1

Cole Ekberg, M.L., Raposa, K.B., Ferguson, W.S., Ruddock, K., Watson, E.B., 2017. Development and Application of a Method to Identify Salt Marsh Vulnerability to Sea Level Rise. Estuaries and Coasts. https://doi.org/10.1007/s12237-017-0219-0 
Crotty, S.M., Angelini, C., Bertness, M.D., 2017. Multiple stressors and the potential for synergistic loss of New England salt marshes. PLoS One. https://doi.org/10.1371/journal.pone.0183058

Frumhoff, P.C., McCarthy, J.J., Melillo, J.M., Moser, S.C., Wuebbles, D.J., 2007. Confronting Climate Change in the US Northeast: Science, Impacts and Solutions. Synth. Rep. Northeast Clim. Impacts Assess.

Hanson, A.R., Shriver, W.G., 2006. Hanson, A.R., Shriver, W.G., 2006. Breeding birds of northeast salt marshes: Habitat use and conservation. Stud. in Avian Biol. Conserv. 32, 141-154.

Hartig, E.K., Kolker, A.S., Gornit, V.C., 2000. Climate change impacts on saltmarsh morphology in Jamaica Bay, New York City. 11th Int. Peat Congr.

IPCC., 2014. Climate Change 2013: The Physical Science Basis: Working Group I Contribution to the IPCC Fifth Assessment Report. Annex 1 1-85. https://doi.org/10.1017/CBO9781107415324.Summary

Kirwan, M.L., Megonigal, J.P., 2013. Tidal wetland stability in the face of human impacts and sea-level rise. Nature. https://doi.org/10.1038/nature12856

Kutcher, T., 2019. Salt marsh rapid assessment methods, MarshRAM: Analysis and Application. Technical report prepared for the Rhode Island Department of Environmental Management and the Rhode Island Coastal Resources Management Council

Leonard, L.A., Luther, M.E., 1995. Flow hydrodynamics in tidal marsh canopies. Limnol. Oceanogr. 40, 1474-1484. https://doi.org/10.4319/lo.1995.40.8.1474

McNeeley, S.M., 2012. Examining barriers and opportunities for sustainable adaptation to climate change in Interior Alaska. Clim. Change https://doi.org/10.1007/s10584-011-0158-X

Narayan, S., Beck, M.W., Wilson, P., Thomas, C.J., Guerrero, A., Shepard, C.C., Reguero, B.G., Franco, G., Ingram, J.C., Trespalacios, D., 2017. The Value of Coastal Wetlands for Flood Damage Reduction in the Northeastern USA. Sci. Rep. https://doi.org/10.1038/s41598-017-09269-Z

Raposa, K.B., Kutcher, T., Ferguson, W., Cole Ekberg, M., Weber, R.L.J., Chaffee, C., 2016. A strategy for developing a salt marsh monitoring and assessment program for the state of Rhode Island. Prepared by Narragansett Bay National Estuarine Research Reserve and Save the Bay 
Raposa, K.B., McKinney, R.A., Wigand, C., Hollister, J.W., Lovall, C., Szura, K., Gurak, J.A., McNamee, J., Raithel, C., Watson, E.B., 2018. Top-down and bottom-up controls on southern New England salt marsh crab populations. PeerJ. https://doi.org/10.7717/peerj.4876

Raposa, K.B., Roman, C.T., 2006. Seasonal habitat-use patterns of nekton in a tide-restricted and unrestricted New England salt marsh. Wetlands 21, 451461. https://doi.org/10.1672/0277-5212(2001)021[0451:shupon]2.0.co;2

Raposa, K.B., Weber, R.L.J., Ekberg, M.C., Ferguson, W., 2017. Vegetation Dynamics in Rhode Island Salt Marshes During a Period of Accelerating Sea Level Rise and Extreme Sea Level Events. Estuaries and Coasts 40, 640-650. https://doi.org/10.1007/s12237-015-0018-4

Redfield, A.C., 1972. Development of a New England Salt Marsh. Ecol. Monogr. 42, 201-237. https://doi.org/10.2307/1942263

Salafsky, N., Margoluis, R., Redford, K., 2001. Adaptive Management: A tool for conservation practitioners. Washington, D.C.: Biodiversity Support Program. Adaptive Management:

Sallenger, A.H., Doran, K.S., Howd, P.A., 2012. Hotspot of accelerated sea-level rise on the Atlantic coast of North America. Nat. Clim. Chang. 2, 884-888. https://doi.org/10.1038/nclimate1597

SLAMM, version 6. 2009. Sea level affecting marshes model. Warren Pinnacle Consulting, Inc. P.O. Box 315, Waitsfield, VT, 05673.

Smith, E.P., 2014. BACI Design, in: Wiley StatsRef: Statistics Reference Online. https://doi.org/10.1002/9781118445112.stat07659

Stein, B.A., Staudt, A., Cross, M.S., Dubois, N.S., Enquist, C., Griffis, R., Hansen, L.J., Hellmann, J.J., Lawler, J.J., Nelson, E.J., Pairis, A., 2013. Preparing for and managing change: Climate adaptation for biodiversity and ecosystems. Front. Ecol. Environ. https://doi.org/10.1890/120277

Sutton-Grier, A.E., Wowk, K., Bamford, H., 2015. Future of our coasts: The potential for natural and hybrid infrastructure to enhance the resilience of our coastal communities, economies and ecosystems. Environ. Sci. Policy. https://doi.org/10.1016/j.envsci.2015.04.006

Watson, E.B., Wigand, C., Davey, E.W., Andrews, H.M., Bishop, J., Raposa, K.B., 2017. Wetland Loss Patterns and Inundation-Productivity Relationships Prognosticate Widespread Salt Marsh Loss for Southern New England. Estuaries and Coasts. https://doi.org/10.1007/s12237-016-0069-1 
Weston, N.B., 2014. Declining Sediments and Rising Seas: An Unfortunate Convergence for Tidal Wetlands. Estuaries and Coasts 37, 1-23. https://doi.org/10.1007/s12237-013-9654-8

Wigand, C., Ardito, T., Chaffee, C., Ferguson, W., Paton, S., Raposa, K., Vandemoer, C., Watson, E., 2017. A Climate Change Adaptation Strategy for Management of Coastal Marsh Systems. Estuaries and Coasts 40, 682-693. https://doi.org/10.1007/s12237-015-0003-y

Williams, B.K., 2011. Adaptive management of natural resources-framework and issues. J Environ Manage. 92, 1346-135 